\title{
REALIGNING LIFESTYLE
}

An integrated approach to living, ecology and production within rural subdivision 

Realigning Lifestyle: an integrated approach to living, ecology and production within rural subdivision

By

Monica Wong

A 120-point thesis

submitted to the Victoria University of Wellington in partial fulfilment of the requirements for the

degree of Master of Landscape Architecture

Victoria University of Wellington

School of Architecture 


\section{ABSTRACT}

The Kapiti Coast is changing. The long awaited expansion of the state highway will see rapid growth along the coast and with it, the rural landscape will face a new set of challenges. As the demand for rural land increases, so does land-use tension. Productive land, which was once converted from an extensive wetland network, is slowly being redeveloped into residential subdivisions in order to fulfil an increasing demand for the country lifestyle. However, lifestyle blocks usually have little productive value and subdivisions fragment natural habitats and ecological systems.

The typical method of dealing with land-use is the district plan, which designates the most appropriate land-use to the most appropriate area. However, despite good intentions, it has become increasingly apparent that this planning process is no longer reaching its desired outcome. This thesis will explore new strategies for designing rural-residential subdivision, aiming to address land-use issues through increasing diversity.

Set in the beach hamlet of Peka Peka, the design investigates one of the last undeveloped areas of private coastal land in the district. This area is prime real estate, but also holds a high capacity for production. It is situated on the remnants of the Great Swamp, a large network of interconnecting wetlands that used to span the length of the coast, providing the potential to significantly increase the ecological value of this land. The design embraces the opportunity to use the residential development as an economic driver to help this degraded landscape and turn these investments into something that is not only beneficial to its residents, but beneficial to the larger region. 


\section{ACKNOWLEDGEMENTS}

Firstly, I would like to thank my supervisors, Martin Bryant and Sam Kebbell, for your guidance over the past 12 months. Your advice has be invaluable and I am grateful to have had the opportunity to learn from both of you.

To the rest of the landscape department at Victoria for your continued support in many things, whether it be advice on my thesis or just general encouragement.

To my family for supporting me throughout my studies and having faith in my decisions, even though I'm sure you still do not understand what I do.

To my friends here in Wellington, thank you for listening to my endless worries and reassuring me when times got tough.

Lastly, to my colleagues who have been with me for the past five years. This thesis would have not been possible without our endless discussions and hours of procrastination. I look forward to when our paths cross again. 


\title{
CONTENTS
}

\author{
$\checkmark \quad$ Abstract \\ vii Acknowledgements
}

01

Introduction

p.2 The Problem

p.4 Scope

p.4 Research Intention

p.6 Research Methodology

p.8 Thesis Structure

02

Setting the Scene

p.12 Land-use Planning

p.16 The Kapiti Coast

p.28 Peka Peka

p.42 The Lifestyle Block 
03

The Design

p.48 Project Overview

p.50 A Strategy

p.51 An Objective

p.52 A Proposal

p.64 A Space

p.86 An Application

\section{5}

\section{Conclusion}
p.118 Conclusion
p.123 Bibliography
p.127 List of Figures

\section{4}

\section{A Discussion}
p.90 Introduction
p.92 Lifestyle
p.100 Scale
p.108 System 

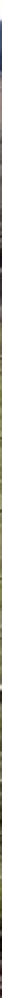

*.

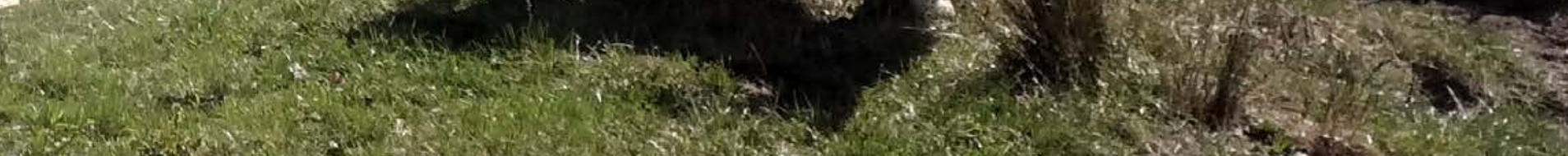

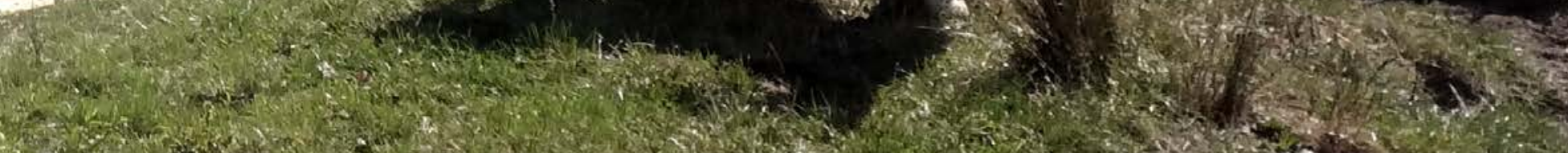

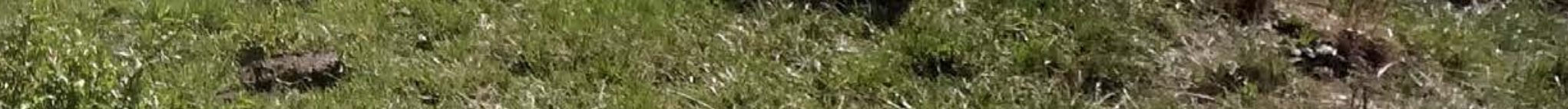

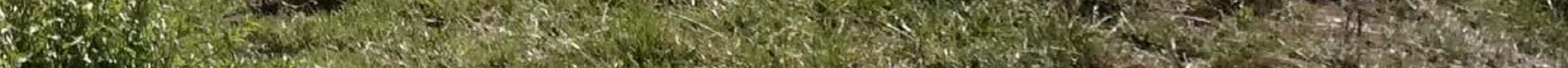

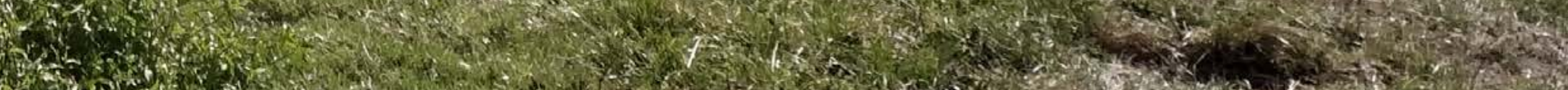

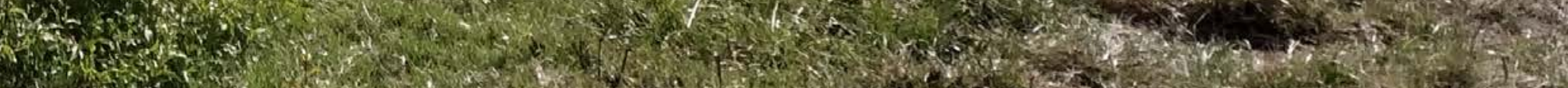

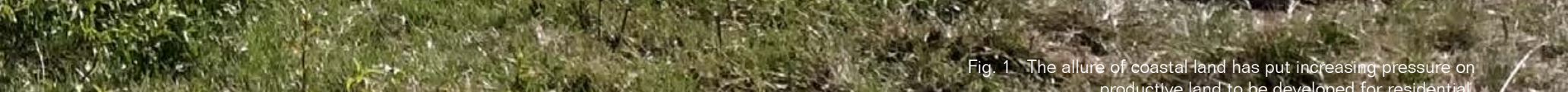
1.6. 46) 4. 1 (1)

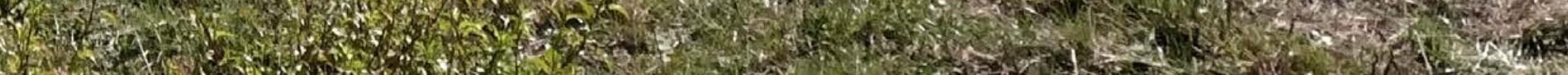





\section{INTRODUCTION}

\section{Chapter One}

"There is therefore a planned development of land use. But is there also a planned development of landscape?"

Roelof Jan Bentem - Reconstruction and Treatment of Rural Landscape [1964] 


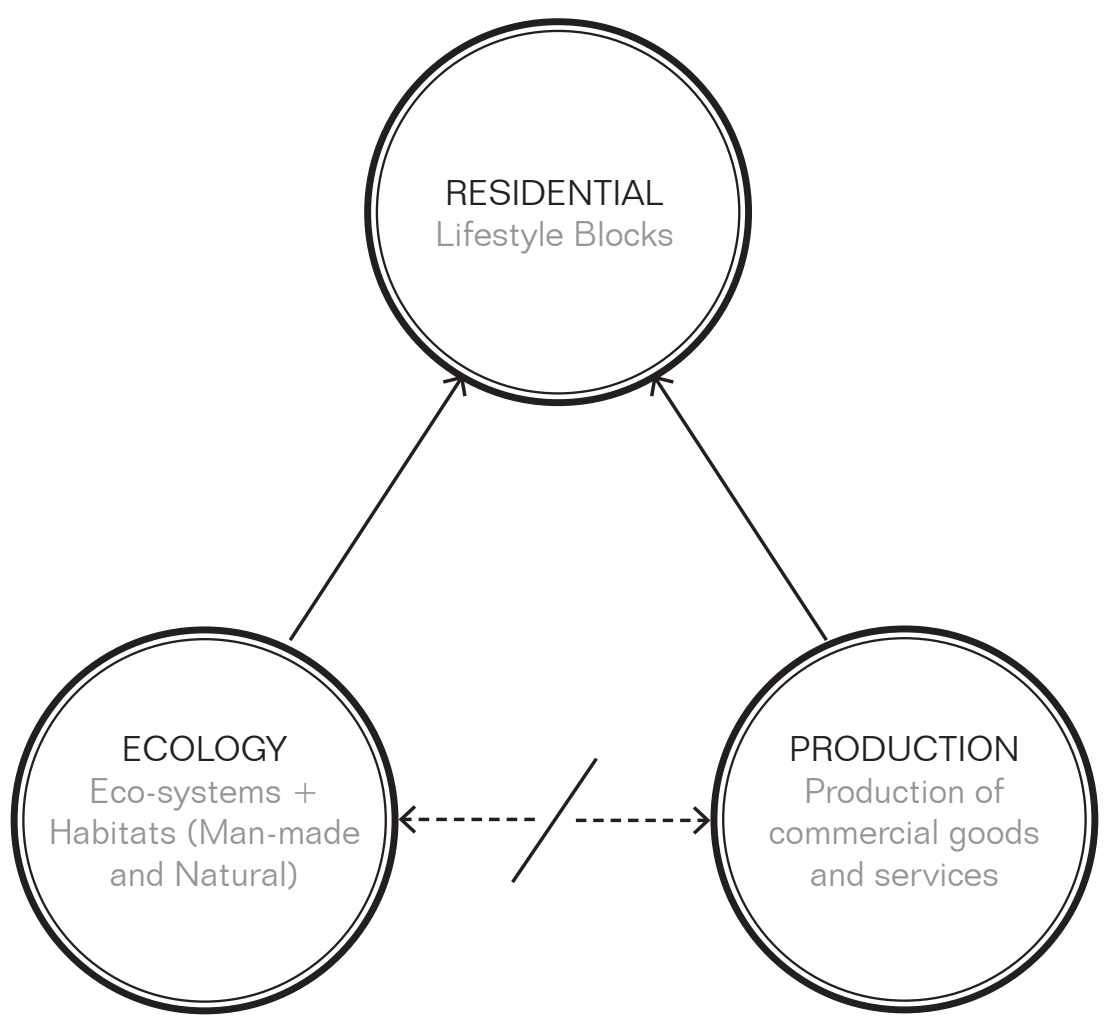

Fig. 2 Rural land previously dedicated to ecology and production is slowly being turned into lifestyle blocks. 


\subsection{THE PROBLEM}

In New Zealand, land is constantly under pressure from a range of competing land-uses. As a result, it is becoming increasingly disconnected and fragmented. The demand for lifestyle blocks is considered a key driver of land fragmentation within rural areas, causing a number of issues including the reduction of land available for primary production, an increased demand for resources and infrastructure, and uncertain changes to ecological habitats (Hart et al. 1). This is an issue for landuse planning, which traditionally designates the most appropriate use to the most appropriate area, but the disconnection from the ground conditions means the planning process is too often not achieving its desired outcome.

Kapiti Coast, the focus area for this research, has experienced a number of issues as a result of this approach to land-use planning; productive land is degrading, ecological habitats are becoming disconnected and the demand for residential development is turning high capability land into urban sprawl which is neither productive nor ecological. Designers and planners seldom acknowledge that these competing land-uses can work together to produce multiple benefits.

This provides the opportunity to suggest a new method of dealing with land-use tension, using design research to address key issues that traditional land-use planning does not. 


\subsection{SCOPE}

This research investigates the continued pressure to subdivide rural land along the coast for residential purposes. It focuses on the Kapiti Coast, a coastal region located north of Wellington, New Zealand's capital city. The design is based in the settlement of Peka Peka, a small beach hamlet which consists largely of lifestyle blocks and beach houses.

The coastal strip between Peka Peka and Te Horo is one of the last undeveloped areas of private coastal land in the district, making it a key area for investigation. This area previously boasted an extensive network of wetlands, which have now been drained for farming purposes.

A lifestyle block is defined as a semi-rural property comprising of a house and land for small-scale farming which can be a secondary source of income. This land is sometimes used purely for recreation.

\subsection{INTENTION}

By proposing an alternative method of dealing with land-use tension, this research aims to confront the disconnection between traditional land-use planning and its desired outcome.

It explores the notion of increasing diversity, suggesting that the integration of land-use as an alternative approach to land-use is a key design consideration to begin solving Kapiti's issues by creating multiple benefits.

It also recognises that the pressure for residential development is not necessarily a problem, but instead provides an opportunity to help the degraded landscape. 


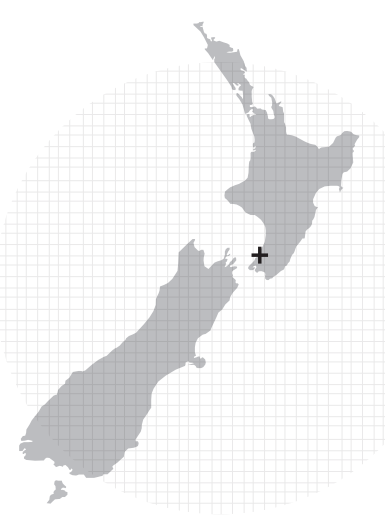

New Zealand

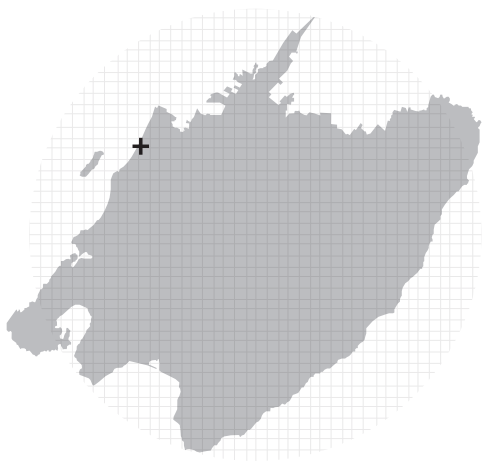

Wellington Region

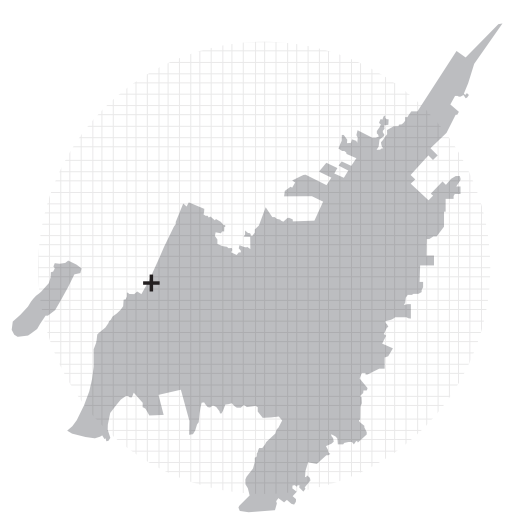

Kapiti Coast

+ Peka Peka

Fig. 3 Location of research within New Zealand. 


\subsection{RESEARCH METHODOLOGY}

As a design-led thesis, the design follows a site-responsive, iterative process. Design iterations tested various aspects of the project, moving between scales and driven by the data available. These iterations were reviewed throughtout the year and given critical feedback. This evaluation allowed the design response to be refined against the initial research intention.

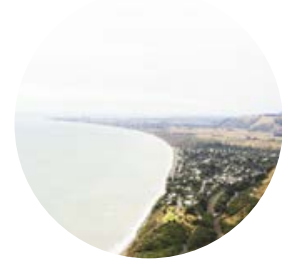

Regional Analysis

- Defining a problem

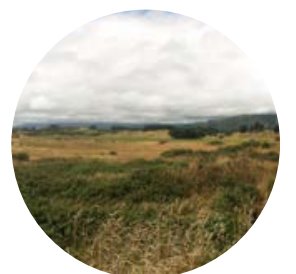

Site Selection

- Where is this problem most relevant?

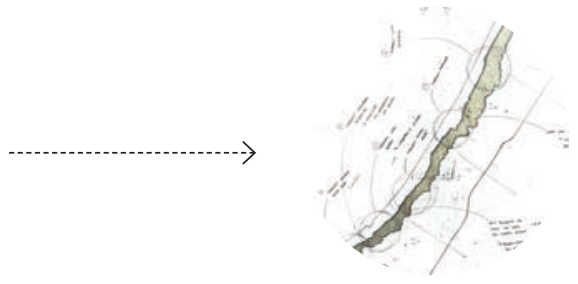

Analysis

Data collection through desktop studies

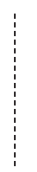

Site Analysis

Theoretical Input<smiles>CC[Tl]</smiles>

Case Studies

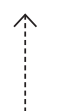




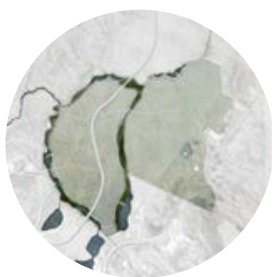

Design Iterations

- Testing in relation to initial

objectives + problem

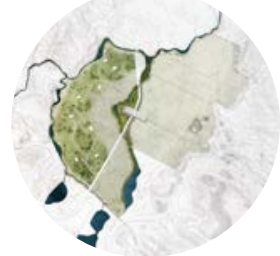

Final Design

- Design outcome from testing

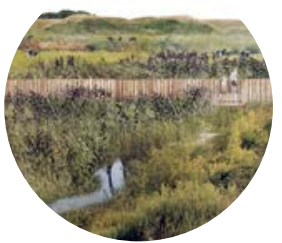

Theoretical Outcomes

- How does this contribute to landscape architecture

Regional Impact

Reflection

Site Planning

Designing Space

Fig. 4 Diagram illustrates the design process. 


\subsection{THESIS STRUCTURE}

This thesis is split into three main sections; context, design and discussion. Reflecting the intention of a design-led thesis, a large emphasis has been placed on the developed design as the core of this research.

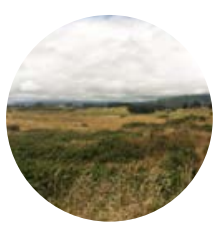

Fig. 5 Site Photo.

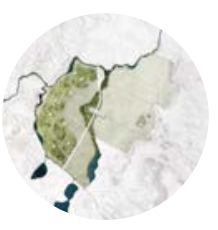

Fig. 6 Site Plan.

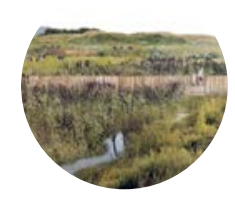

Fig. 7 Final Design
Chapter 2: Setting the Scene

This chapter will discuss the relevant issues regarding land-use planning, the Kapiti Coast and the site conditions. It will outline the basis of which the design was built upon.

\section{Chapter 3: A Design}

This chapter will present the developed design. It is split into five sections which each express a different scale of the design. While it is site-specific, the design is envisioned as a model that could be applied to other parts of the Kapiti Coast.

\section{Chapter 4: A Discussion}

This chapter will discuss the design outcomes in relation to three key topics; rural subdivision, scale and the creation of a system. Each of these three topics are discussed in relation to the relevant case studies and design exploration that led to these outcomes. 


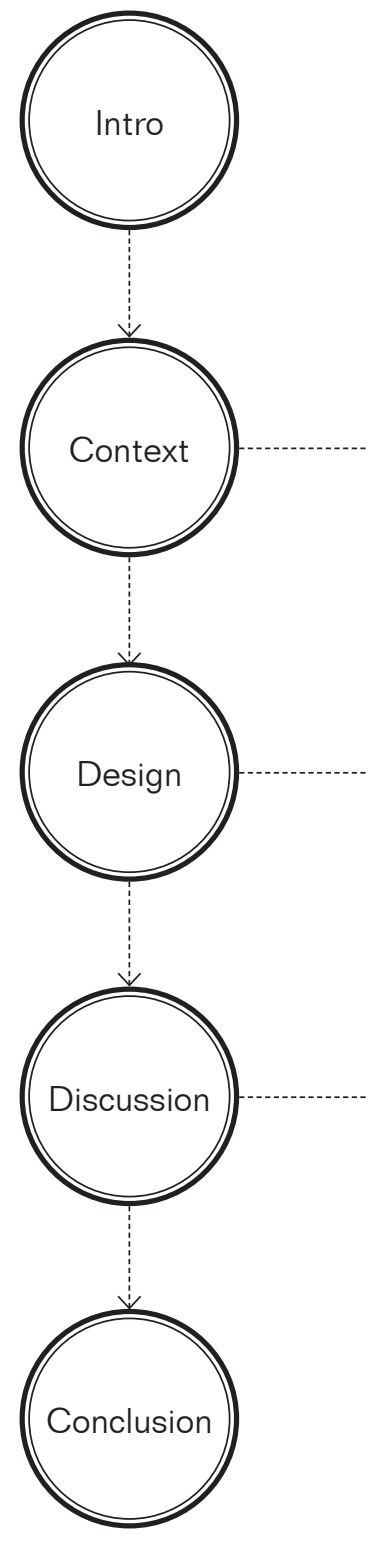

Disciplinary Issues

Site Specific

Design

Design

Outcomes
Site

Analysis
Case

Studies
Design

Exploration

Fig. 8 Diagram illustrates the structure of the thesis. 


\title{
SETTING THE SCENE
}

\author{
Chapter Two
}

"New Zealand's agricultural landscape differs from the long established overseas landscapes. We have fewer historical cultural features to protect, but many more natural landscapes to treasure" 


\subsection{LAND-USE PLANNING THE DISTRICT PLAN}

Currently, land-use is dictated through the district plan. Planners rely on the district plan to regulate and control design, but what is rarely acknowledged is its inability to produce good design. Objectives from Kapiti Coast's district plan recognise and support many key issues; the importance of local food supplies, the creation of a resilient community, but the expectation that this will be enough to produce results is a key problem within the planning process. Research conducted into landuse planning in New Zealand showed that the majority of case studies examined (21 out of 24) failed to give effect to the district plan's desired policy intentions and, in some situations, showed a loss of ecological or landscape values (Beattie 5).

The disconnection between planning documents and implementation can be explained by a number of outside factors such as the pressure to develop plans under politically motivated or unrealistic time frames (Beattie 5), but fundamentally it is a design problem. Linda Pollak, in her article "Constructed Ground: Questions of Scale", describes a tendency to view landscape as "an abstract container, separate from the objects, events, and relations that occur within it" (127). This perfectly captures one of the weaknesses of traditional land-use planning, as the district plan itself is an abstracting device. Too often it fails to connect with ground conditions, leaving designers with only a few, specific regulations to follow. Within rural subdivision, this allows developers to do the absolute minimum of what is required, resulting in the disconnection between the planned objectives and the actual outcome. However, it is not regulation and policies that need to be stricter, but rather the approach to design that needs to be stronger. 


\section{Resource Management Act 1991}

Matters of national importance

(a) the preservation of the natural character of the coastal environment, wetlands, lakes and rivers and their margins, and the protection of them from inappropriate subdivision, use, and development

\section{District Plan [Kapiti Coast]}

Objective 2.2 - Ecology and biodiversity

(b) to improve indigenous biological diversity and ecological resilience through the restoration of the ecological integrity of important degraded environments and habitats

\section{Lower Level Policy Frameworks}

Policy 7.9 - Management of conflicting uses

(c) management of effects will include measures such as the use of vegetated buffers along boundaries with sensitive activities for activities characterised by potential nuisance effects

Fig. 9 An example of the tiers of legislation. 
Fig. 10 Kapiti Coast. 


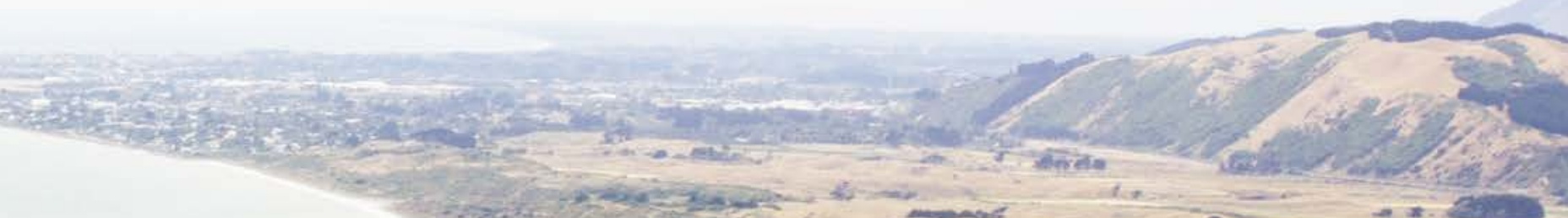

$+$ 

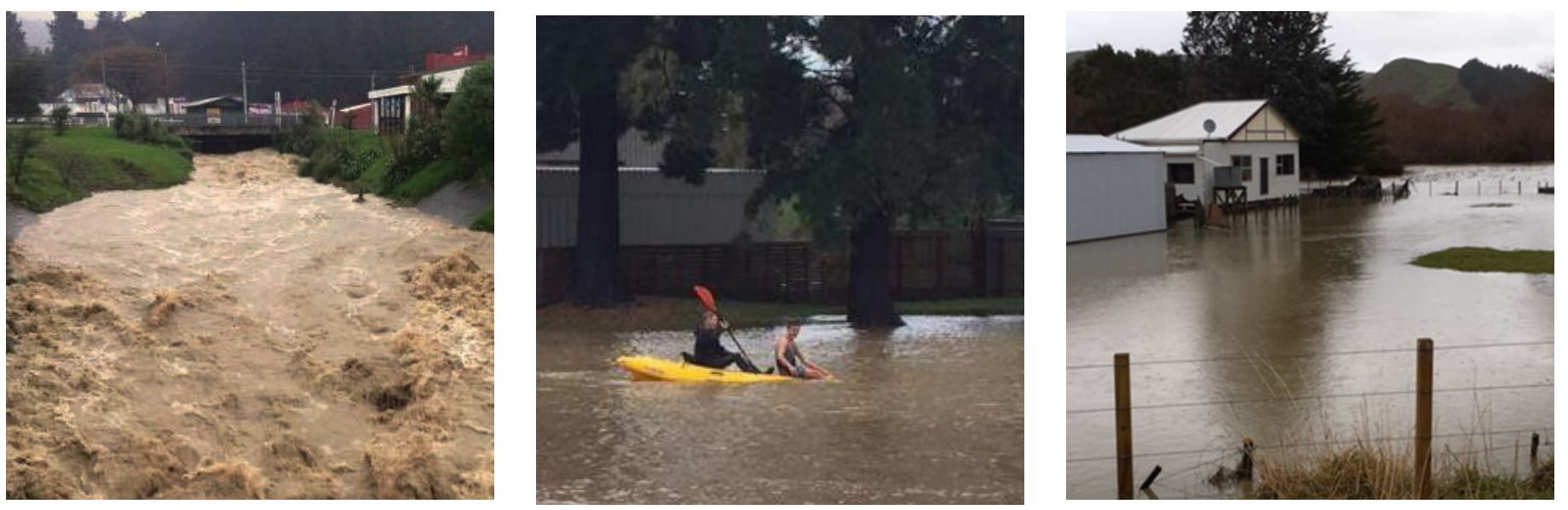

Fig. 11 Flooding in Paraparaumu city centre.

Fig. 12 Kapiti residents kayaking between private properties.

Fig. 13 Flooding within paddocks in rural Kapiti.

Images showed above were taken from the May 2015 floods that caused widespread damage throughout Kapiti. 


\subsection{THE KAPITI COAST \\ WHY KAPITI?}

For decades, architects, planners and economists have all been fascinated with the urban environment. However, it has become increasingly obvious that this fascination has left rural areas neglected and forgotten (Sassen). Rem Koolhas, in his article "Koolhas in the country", argues that "our current obsession with only the city is highly irresponsible because you cannot understand the city without understanding the countryside." Whether it is recognised or not, Wellington city needs the support of its regions which provide important resources such as food and water. It cannot continue to flourish without the region's support and this is a key reason Kapiti is the focus of this research.

Kapiti Coast is the 30 kilometre stretch from Paekakariki to Otaki and is governed by the Kapiti Coast District Council. Its population resides at 49,104 people, a quarter of the population in Wellington's city centre. Over 5,000 people commute from Kapiti to Wellington city for work (Statistics New Zealand). Kapiti Coast has experienced a number of issues in relation to its natural resources and subsequent infrastructure, most notably the water shortages during the summer and the floods during the winter. Suburban sprawl is also a notable problem, as its housing provides a cheaper alternative to Wellington city.

The Kapiti Coast will also face a series of future problems, most notably earthquakes and the aging population. This expresses the importance of becoming a resilient settlement, encouraging diversity, a cohesive community and a systems way of thinking (Walker and Salt). 


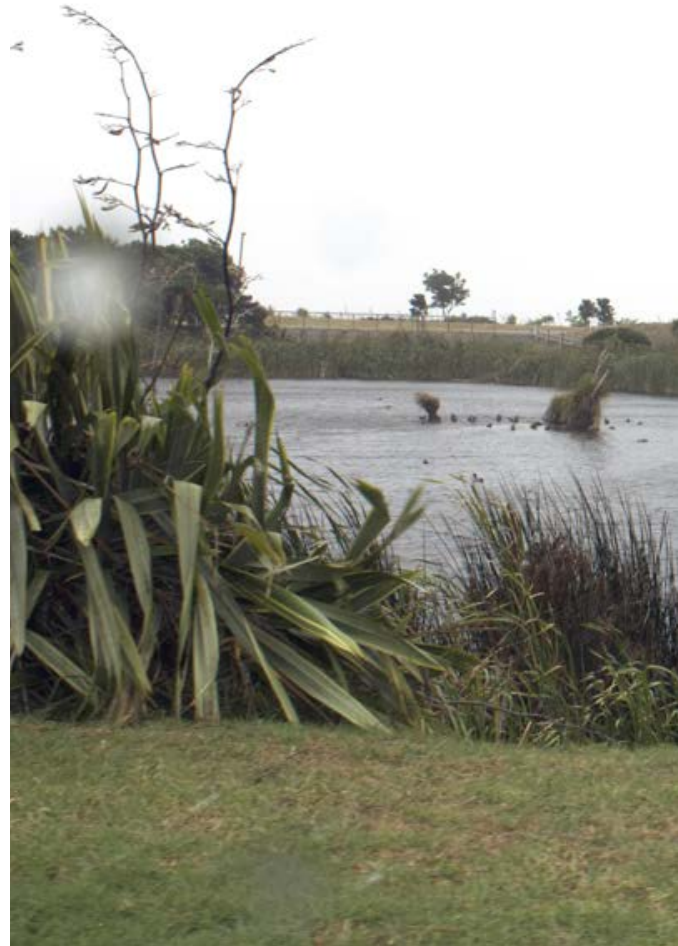

Fig. 14 Scattered wetlands appear throughout the coast.

\subsection{THE KAPITI COAST}

\section{REMNANT WETLANDS AND THE GREAT SWAMP}

The Kapiti Coast has a distinct mosaic of duneland-based wetlands scattered along the coast. Prior to European settlement, these wetlands covered the duneland, creating a series of interconnected wetlands known as the Great Swamp. The network spanned over 2000 hectares and provided early Maori inhabitants with an abundance of food and water. Today, the remnants total less than 300 hectares (Fuller 13). The area in which the Great Swamp used to exist, between the foredunes and the parabolic dunes, have the potential for high levels of biodiversity if it were to be restored to its natural state. However, the majority of this land has been developed into either residential or farmland, making it difficult to reverse the land back to what it once was. This provides a key area for investigation, examining how the past landscape can influence and is influencing the present.

Fig. 15 (Opposite) Current soil conditions illustrate evidence of the Great Swamp. 



\subsection{THE KAPITI COAST}

\section{KAPITI'S AGRICULTURE INDUSTRY}

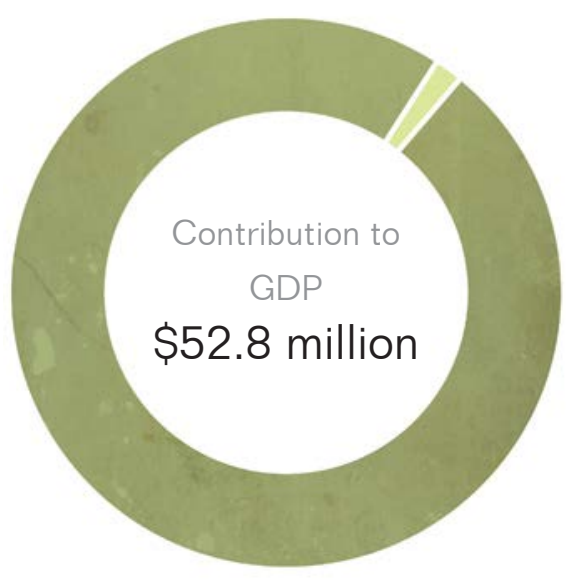

Fig. 16 Agriculture industry's contribution to Kapiti's GDP.

The agriculture industry is a key sector within Kapiti Coast's economy, contributing to $\$ 52.8$ million to GDP in 2013. However, much like the rest of New Zealand, its primary industry has become stagnant in growth, consistently increasing productivity with little economic gain.

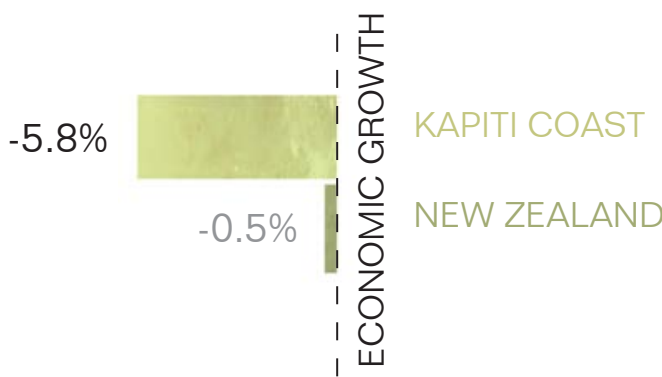

Fig. 17 Comparison of economic growth in the industry.

Economic output in Kapiti's agriculture industry has declined by $5.8 \%$ in 2013 and growth has averaged $-1.7 \%$ pa over the past 10 years (Infometrics). Pastoral farming is also becoming increasingly dynamic with sheep-beef properties supporting the increasing numbers of dairy cows 


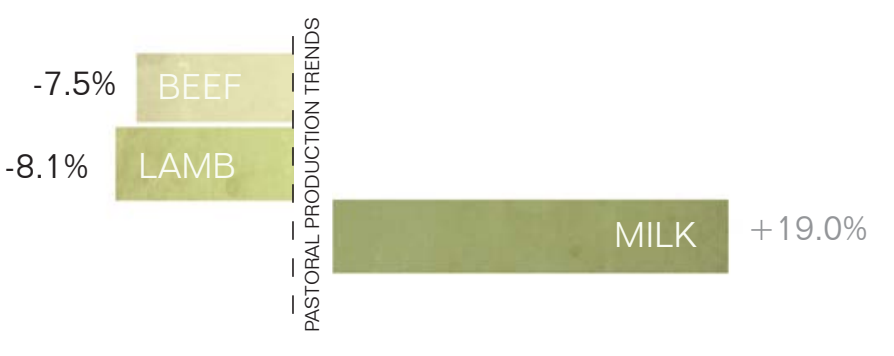

Fig. 18 Pastoral production trends in New Zealand.

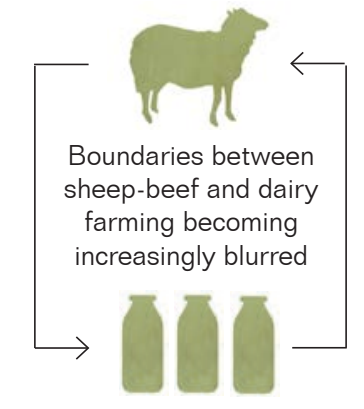

Fig. 19 Farms are becoming increasingly dynamic. through practices such as winter grazing or rearing replacement heifers. This means the distinction between sheep-beef farms and dairy farms are becoming increasingly blurred. Overall, the number of sheep-beef farms continue to fall, while dairy farms rise (Ministry for the Primary Industries).
As there is considerably more input into dairy farms, this means there is likely to be increase in pollution, particularly to New Zealand's waterways (Baskaran, Cullen, Colombo). 


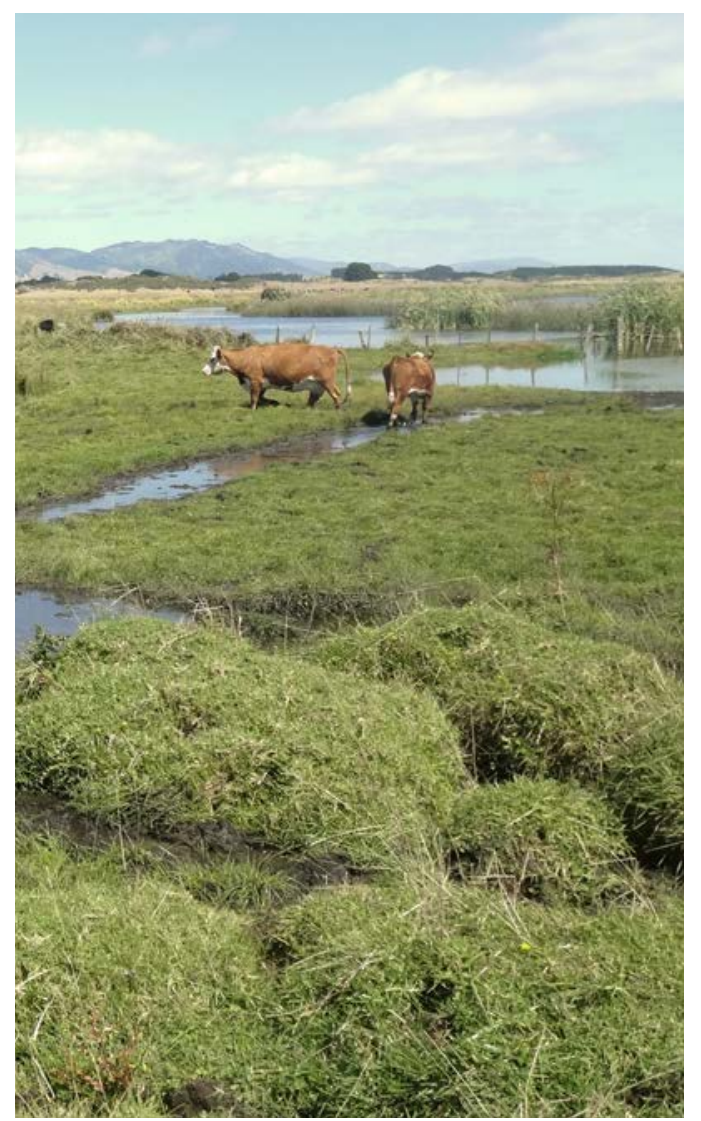

Fig. 20 Too many waterways in Kapiti are easily accessed by cows.

\subsection{THE KAPITI COAST \\ THE FARMING LANDSCAPE [CURRENT LAND-USE]}

Farming types in Kapiti tend to concentrate in one particular area (fig. 21), for example dairy farming in Te Horo. This is due to a number of reasons including the availability of land and the type of soil present. However, this accumulation of land-use has had an adverse effect on the quality of water, decreasing progressively along the coast as the intensity of farming increases (Greater Wellington Regional Council). This means large patches of intense farming readily polluting a single waterway.

As Kapiti's District Plan defines the majority of this land as a 'Rural' area, in which land can easily change its use within the permitted parameters. This creates fluidity within the farming practices, for example switching between livestock and dairy or incorporating forestry within paddocks.

Fig. 21 (Opposite) Land-use Map of Farming in Kapiti. 


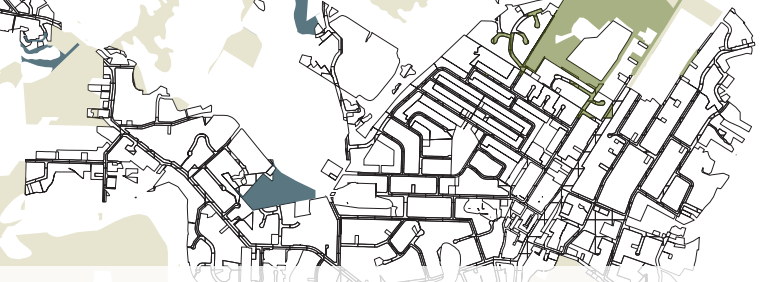




\subsection{THE KAPITI COAST}

\section{THE FARMING LANDSCAPE [MOST SUSTAINABLE + INTENSIVE LAND-USE]}

Figure 22 classifies land according to its suitability to the most intensive, but physically sustainable land-use, based on the New Zealand Land Resource Inventory Land Use Capacity rating. Although some correlation can be seen between this and the current land-use map, the comparison suggests that a greater sensitivity could be employed to the productive landscape. This means farming activities could be more dispersed, relieving pressure on Kapiti's waterways without losing a significant amount of productivity.

\section{Intensive Grazing}

Land with sometimes severe limitations to arable use but capable of supporting intensive grazing with cultivation for pasture renewal or occasional cropping.

\section{Extensive Grazing}

Land unsuitable for arable use with sometimes moderate physical limitations under pasture but capable of extensive grazing use, forestry and, in some cases, vineyards.

\section{Intensive Horticulture}

Land with minimal physical limitations to arable use, capable of multiple land uses including, intensive horticulture.

\section{Cash Cropping}

Land with moderate physical limitations to arable use, not suitable for intensive, short-rotation cropping but capable of extensive field cropping and long-rotation horticulture.

Fig. 22 (Opposite) Map of most intensive, but sustainable land-uses in Kapiti. 

- 


\subsection{THE KAPITI COAST}

\section{LOCATIONS ALONG THE COAST}

State Highway 1

Te Horo

Between Te Horo and Peka Peka is one of the last largely undeveloped coastal areas, considered prime real estate and holds great potential for increasing ecological value

Te Hapua Wetlands, a privately owned complex of restored wetlands

\section{SITE LOCATION}

\section{Peka Peka}

Mackays to Peka Peka, a recent development project expanding the motorway, is likely to cause an increase in development and a rise in population

Demand for coastal land has caused

Waikanae to sprawl up the coast

Waikanae River + Settlement

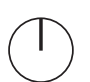

0

1

2 3 



\subsection{PEKA PEKA}

\section{WHY PEKA PEKA?}

Peka Peka is quiet beach settlement in semi-rural surroundings, grown from random beach houses and lifestyle blocks to become a community in its own right. Unlike the rest of the settlements along the coast, Peka Peka does not contain a distinct community centre or any community facilities. It is the everyday landscape, with no outstanding natural features or rich historical significance to define it. However, this is why it is also important. Landscape architecture research and design tends to gravitate towards these sites that have outstanding features, seizing the opportunity to create interesting and unique projects. But if good design fails the everyday landscape, what are we left with? The same favouritism of the urban versus the rural also occurs at this smaller scale, focusing efforts on larger sites such as the Waikanae River and neglecting the potential that can be found within a simple paddock. 


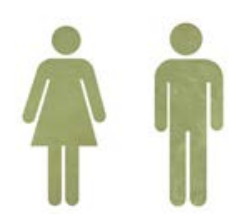

\section{$360 \begin{aligned} & \text { Residents in Peka } \\ & \text { Peka [2013] }\end{aligned}$}

Fig. 24 Number of residents in Peka Peka.

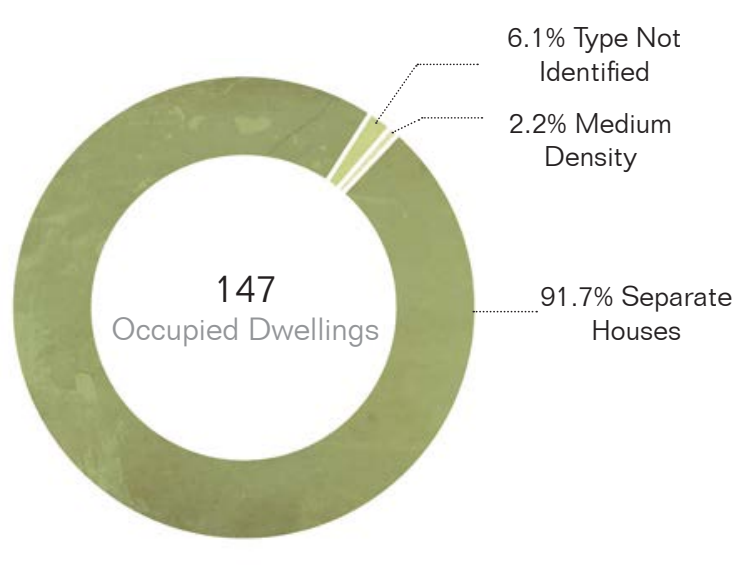

Fig. 26 Dwelling types in Peka Peka.

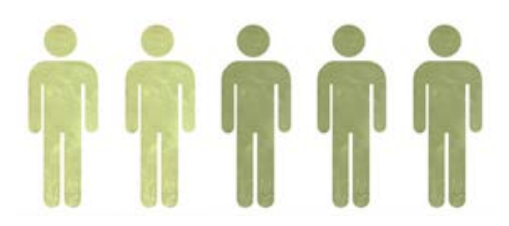

\section{$40 \%$ Growth in Population 2006 to 2013}

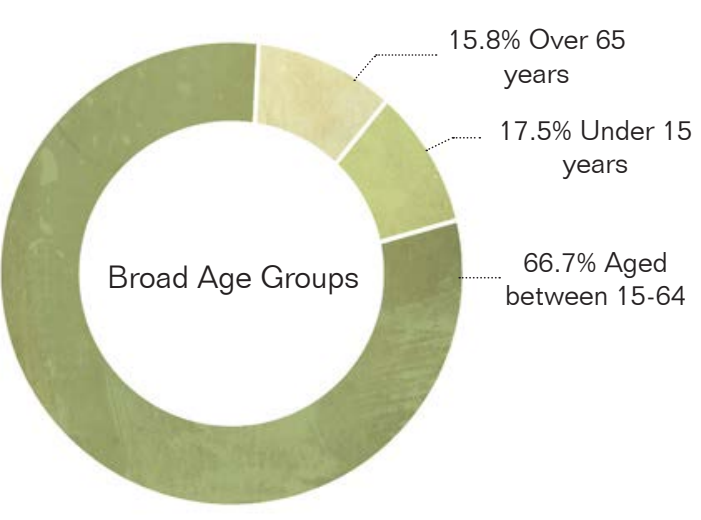

Fig. 27 Broad age groups in Peka Peka. 


\subsection{PEKA PEKA}

\section{SITE EXTENTS}

This area was chosen for this piece of research as it encompasses a range of ecologies, with the dunes and most importantly, a waterway. It is also currently a large, single property and lies on the periphery of a coastal settlement.

The site boundary runs along the legal property boundary.

Te Kowhai Stream

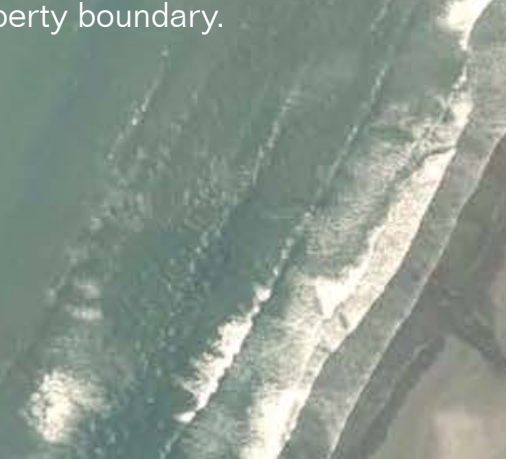




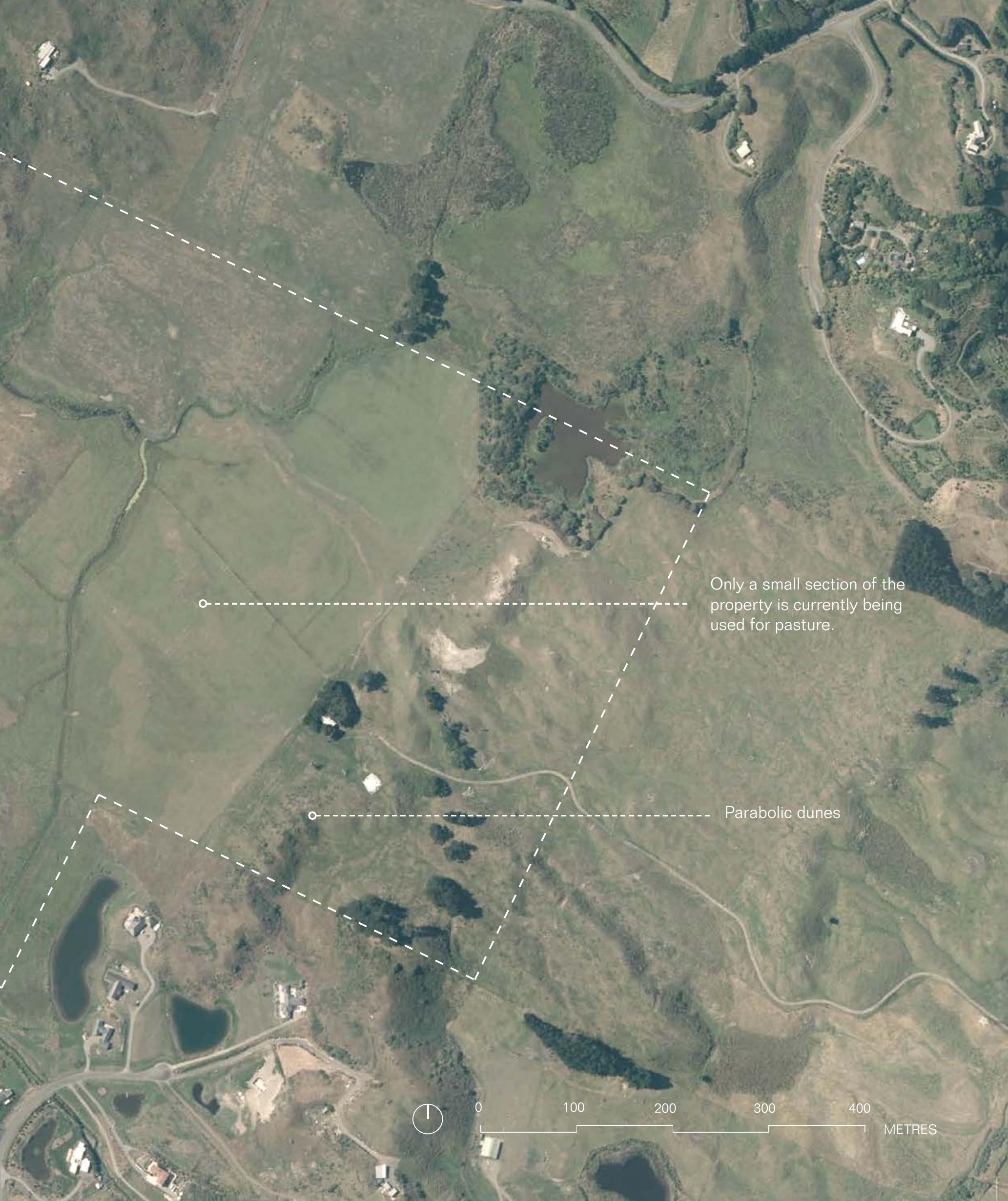




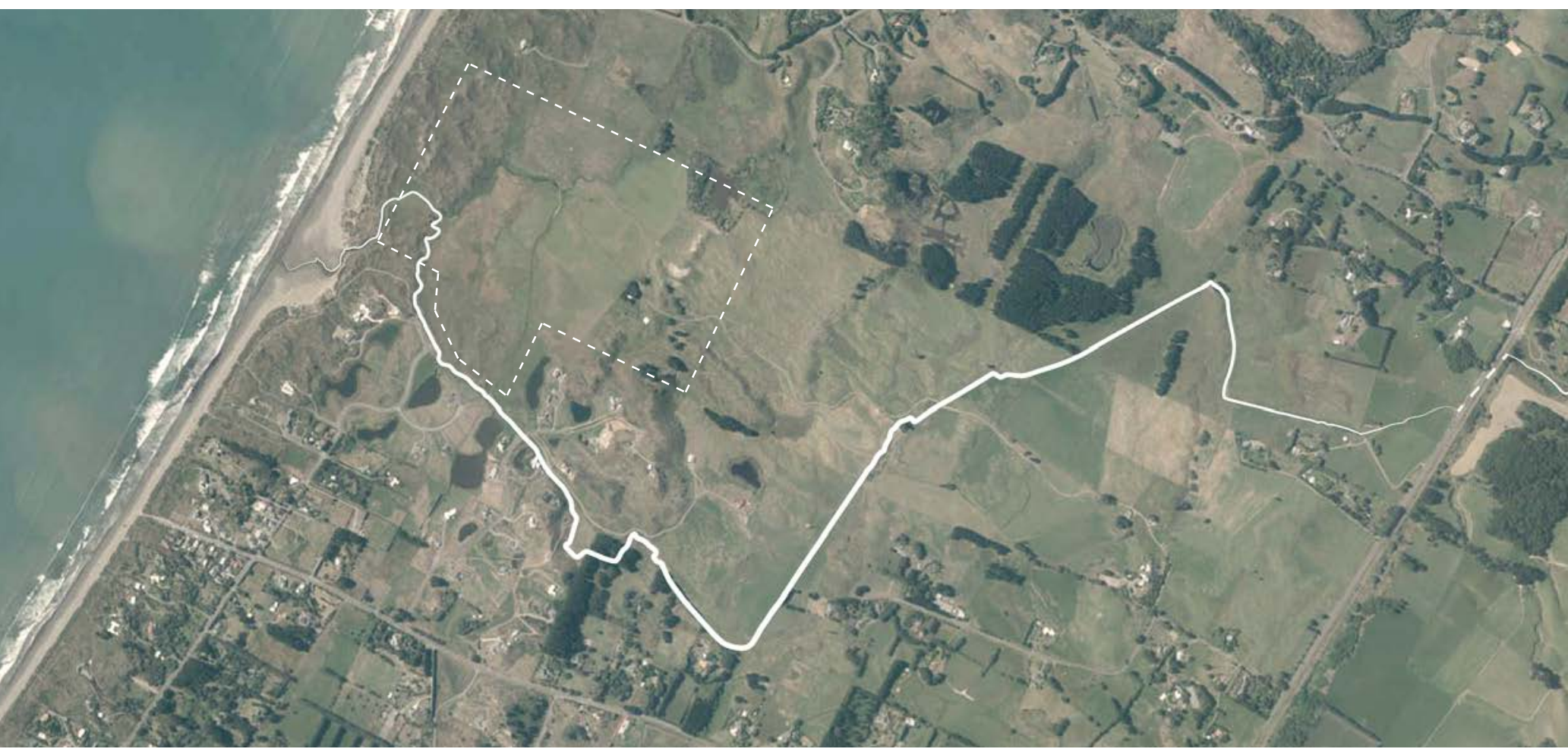

Fig. 29 Locating Te Kowhai Stream/Hadfield Drain. 


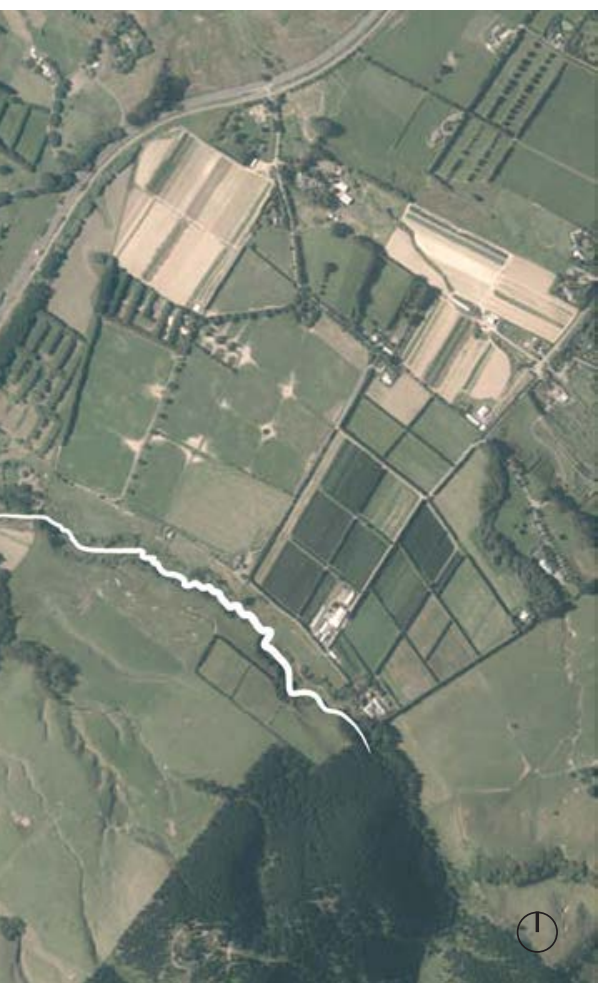

\subsection{PEKA PEKA}

\section{TE KOWHAI STREAM}

The site boundary is parallel to the side of Te Kowhai Stream, also commonly known as Hadfield Drain. The Te Kowhai catchment is relatively small at $10.2 \mathrm{~km}^{2}$ and the stream's headwaters originate in a pine and native forest located in a steep upper catchment. Although the stream currently has good water quality, it has low ecological value due to its highly modified and historically drained nature (NZTA 579). 


\subsection{PEKA PEKA \\ SOIL AND WATER}

The site has been modified with an extensive drain network in order to create viable land for pasture. Only part of the property is currently being used for pasture, likely due to the change in the soil conditions. This leaves half of the property unused, while the other half requires constant draining to remain productive.

The change in soil conditions is an indication of a change in ecology from the dunes to the wetlands

Central drain moves water to the stream

Many smaller drains have been made to drain the pasture

Brown soils occur in places where summer drought is uncommon and are not waterlogged during the winter. They are the most common soil type in New Zealand (Landcare Research). The majority of this area has been taken over by weeds.

Gley soils occur in parts of the landscape that have high groundwatertables, where waterlogging occurs in the winter and spring. Some soils will stay wet all year round and these soils mark the original extent of New Zealand's wetlands (Landcare Research). Gley soils onsite have been extensively drained to allow for the farming. 



\section{SITE CHARACTER}
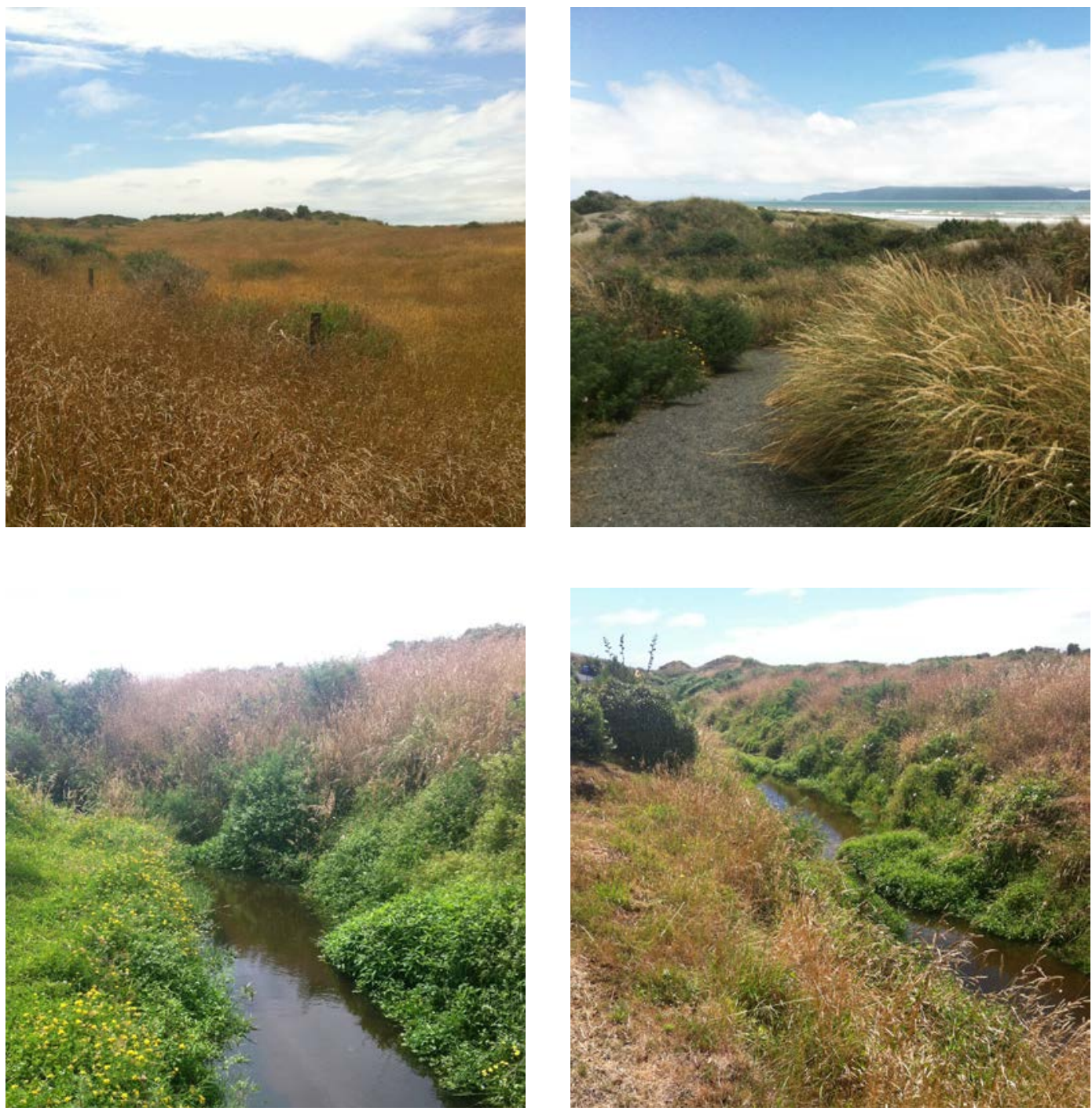

Fig. 31 (top left) Weeds have currently overtaken the site.

Fig. 32 (top right) One of the pathways in Peka Peka leading through the foredunes to the beach.

Fig. 33 (bottom) Te Kowhai Stream during the summer, very little native vegetation is present. 


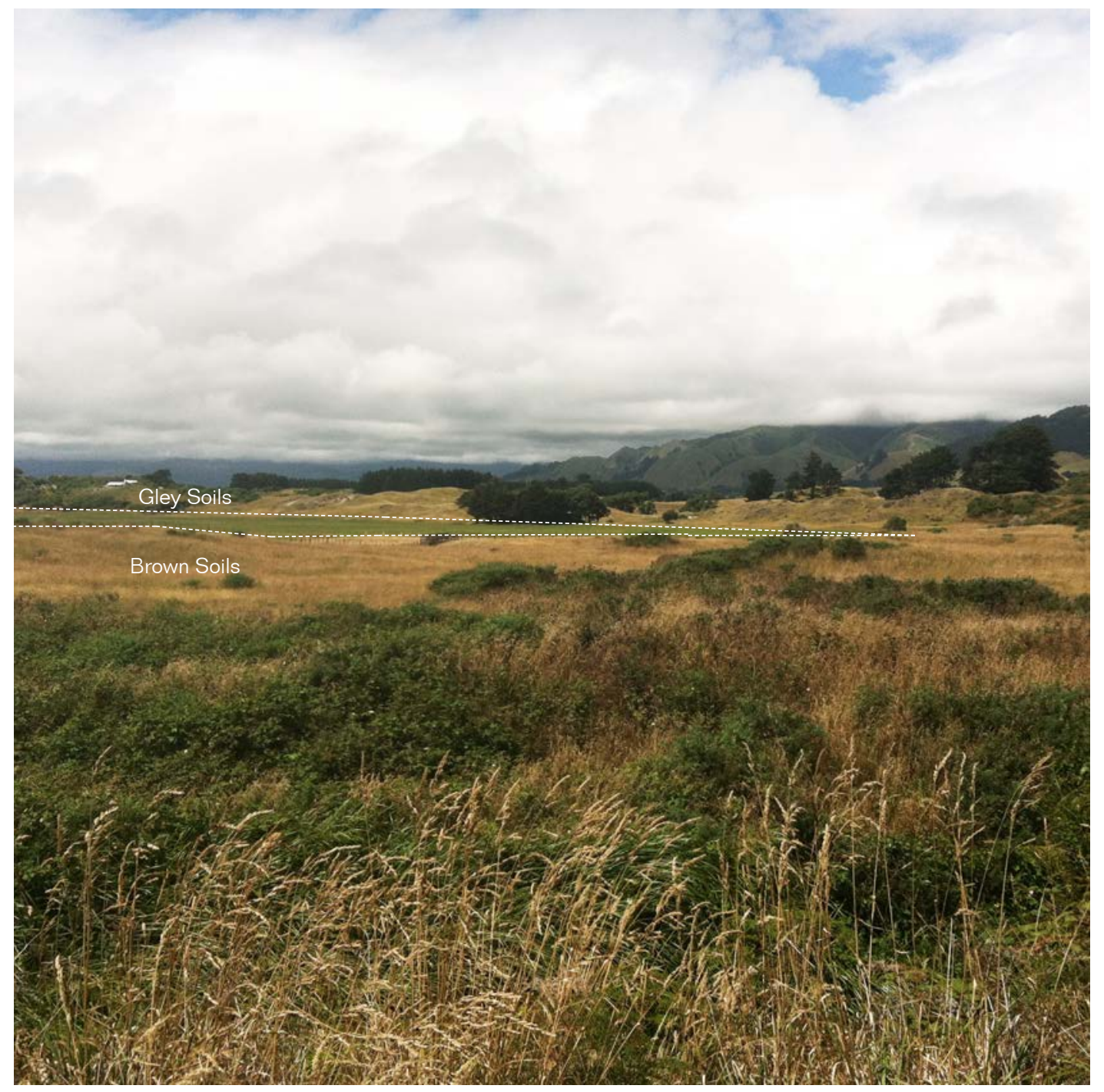

Fig. 34 Only a small section of the site is currently being used for pasture. 


\subsection{PEKA PEKA}

\section{TASMAN LAKES DEVELOPMENT}

The Tasman Lakes Settlement is a new development south of the site which provides a local example of the disconnection between land-use planning documents and the actual implementation. It consists of 28 house sites upon 20 acres of land, which was significantly reduced from the initial scheme which proposed 59 lots upon 40 acres of land. These changes occurred after the Peka Peka Guardians, a local community group, and the Kapiti Environmental Action group appealed the proposed development. Concerns included the creation of new lakes changing the water flow, the amount of earthworks changing the character of the site and the amount of road planned for the amount of lots. The road scheme suggested that Tasman Lakes were preparing for an expansion to the subdivision in the future (Local Government and Environment Select Committee 8).

The main requirements of the District Plan for a subdivision within the Rural Dunes Zone is the protection of landform and ecological character. It also encourages "increases in biodiversity, water quality and energy efficiency" (Kapiti Coast District Council 13). The majority of the housing within the settlement has now been placed in a manner that is sympathetic to the dunes, but restoration to the lakes has been largely ignored. The ecological potential of this landscape is even acknowledged within the District Plan, but the suggestive quality of the policies allows developers to put minimal effort into ecological systems and biodiversity.

Like most development projects, the design of Tasman Lakes works to maximise the amount of properties available to purchase. Instead of increasing the value of the landscape, which is its key selling point, it proposes as many house sites as possible. This, however, limits access to the lakes, discouraging use in fear of intruding on private land. 
Design maximises density within its topographical constraints, encouraging suburban sprawl

Each property is individually managed, creating different regimes and ecology

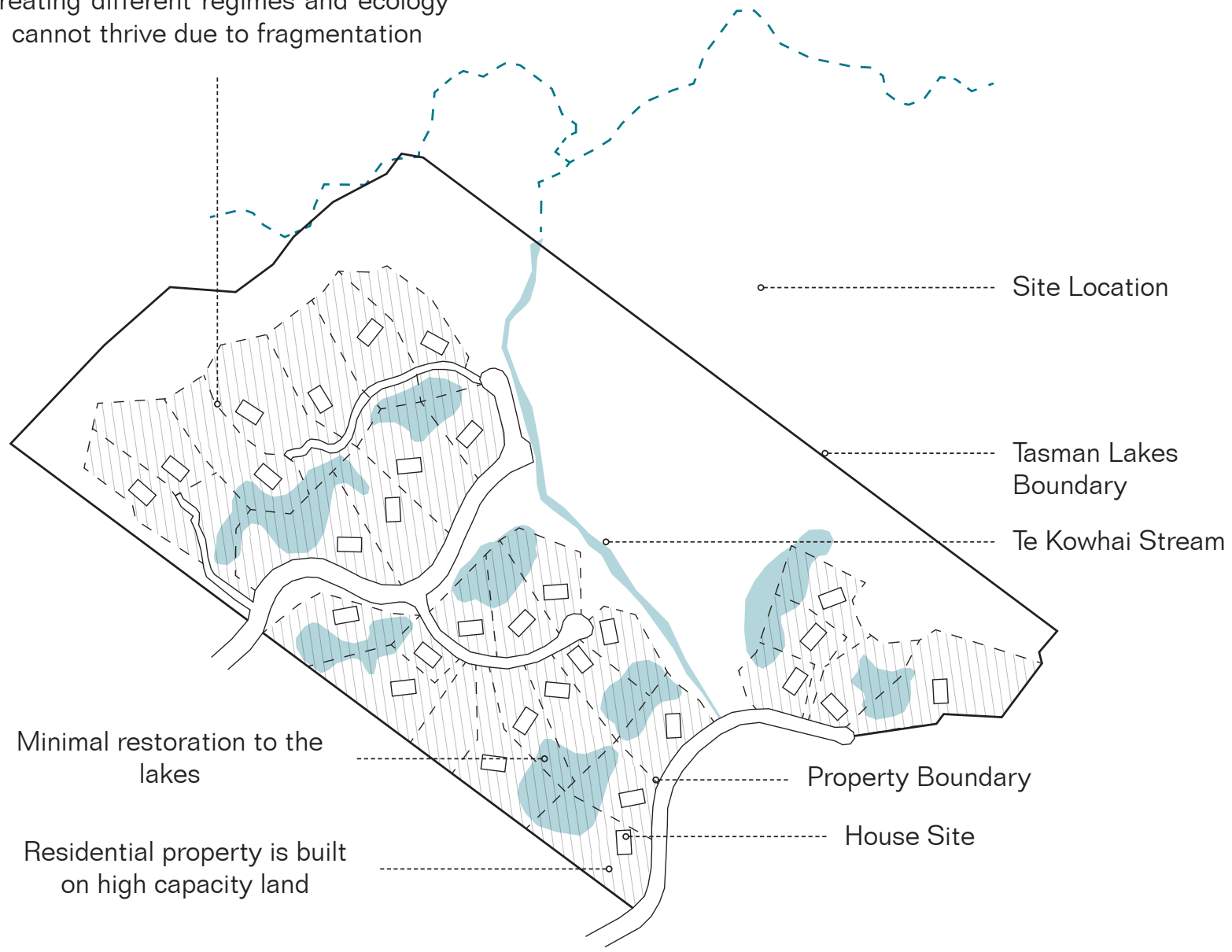




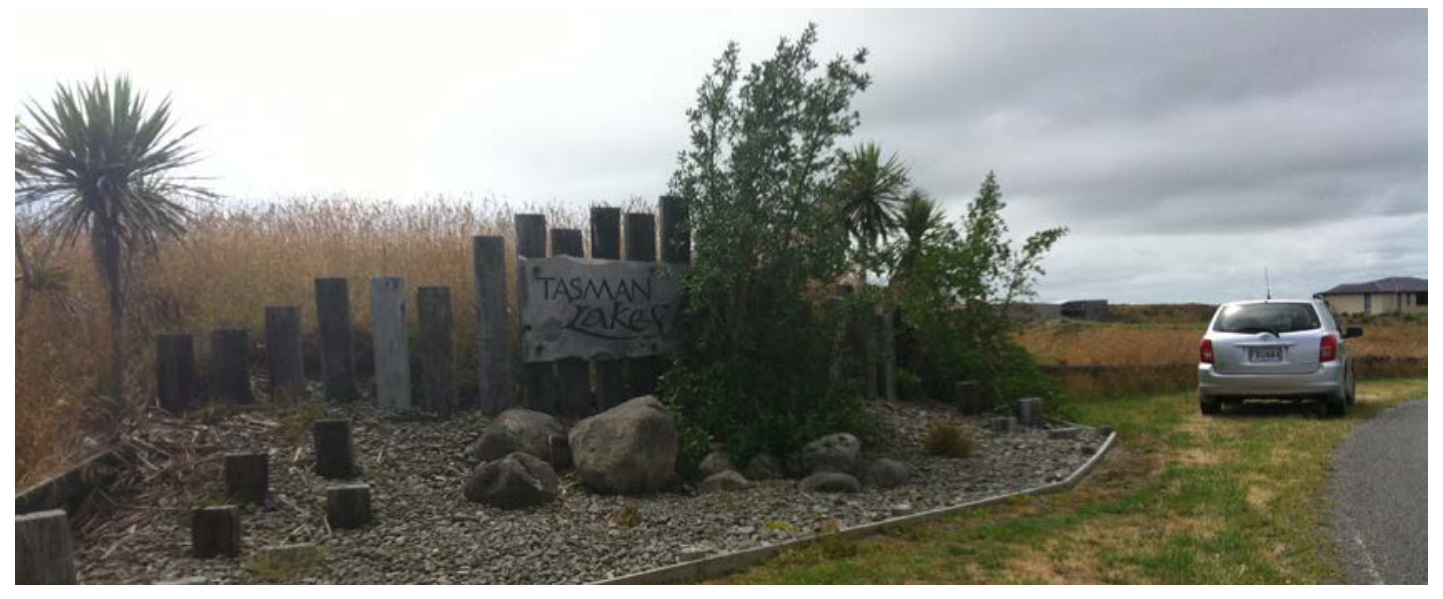

Fig. 36 Small scale design is limited to signage.

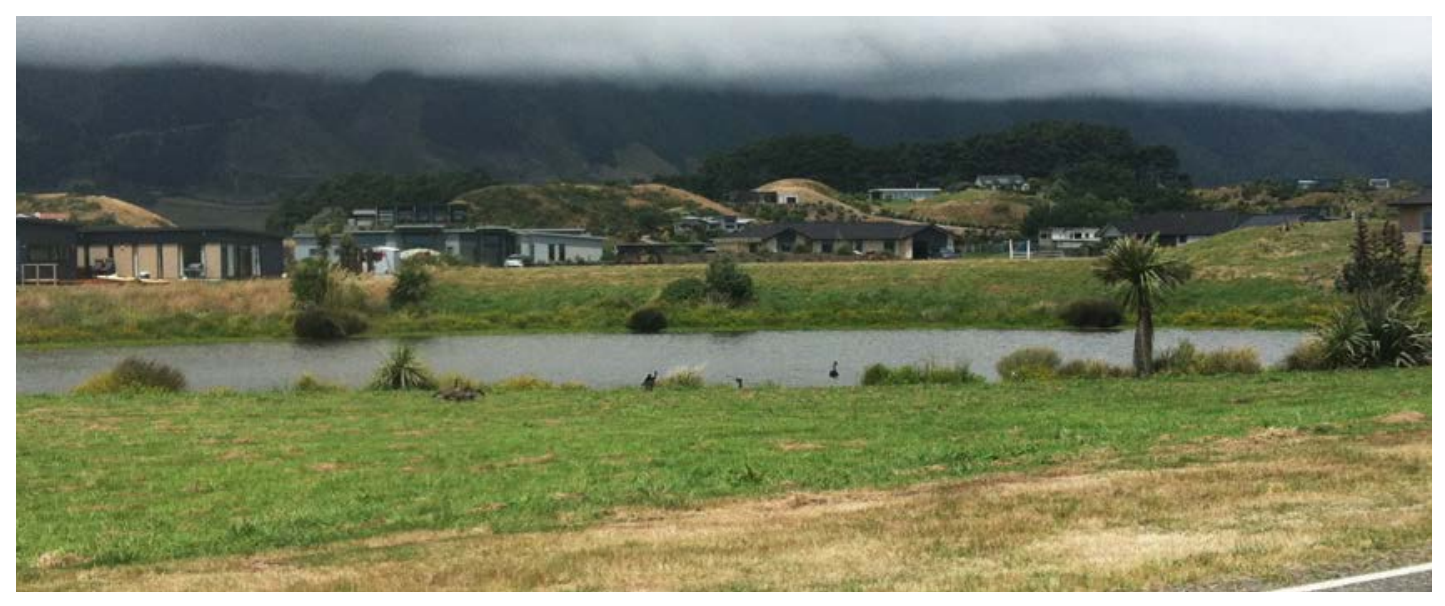

Fig. 37 The lakes are a missed opportunity to add ecological value and fulfil the potential of this landscape. 


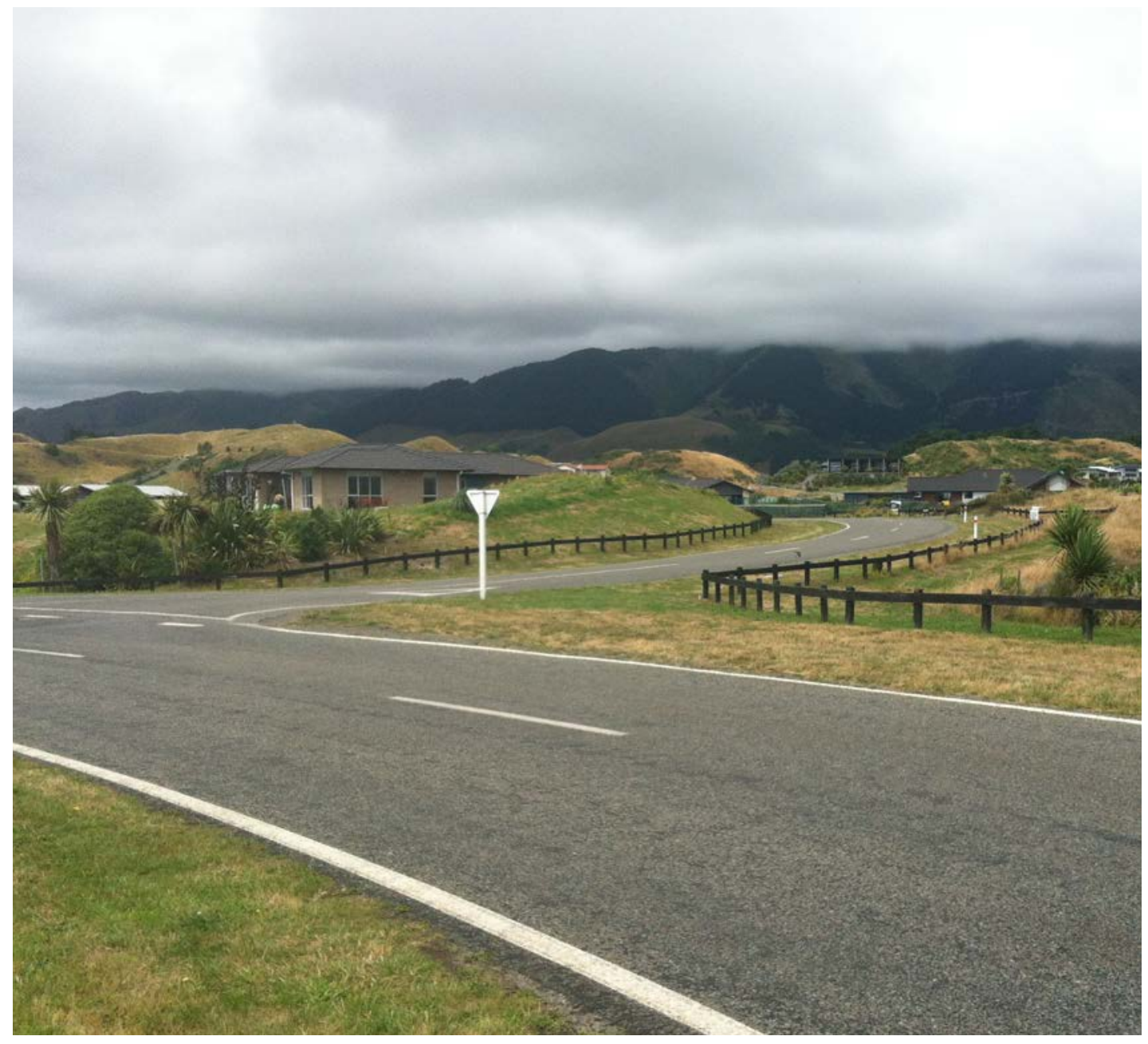

Fig. 38 The Tasman Lakes Settlement. 


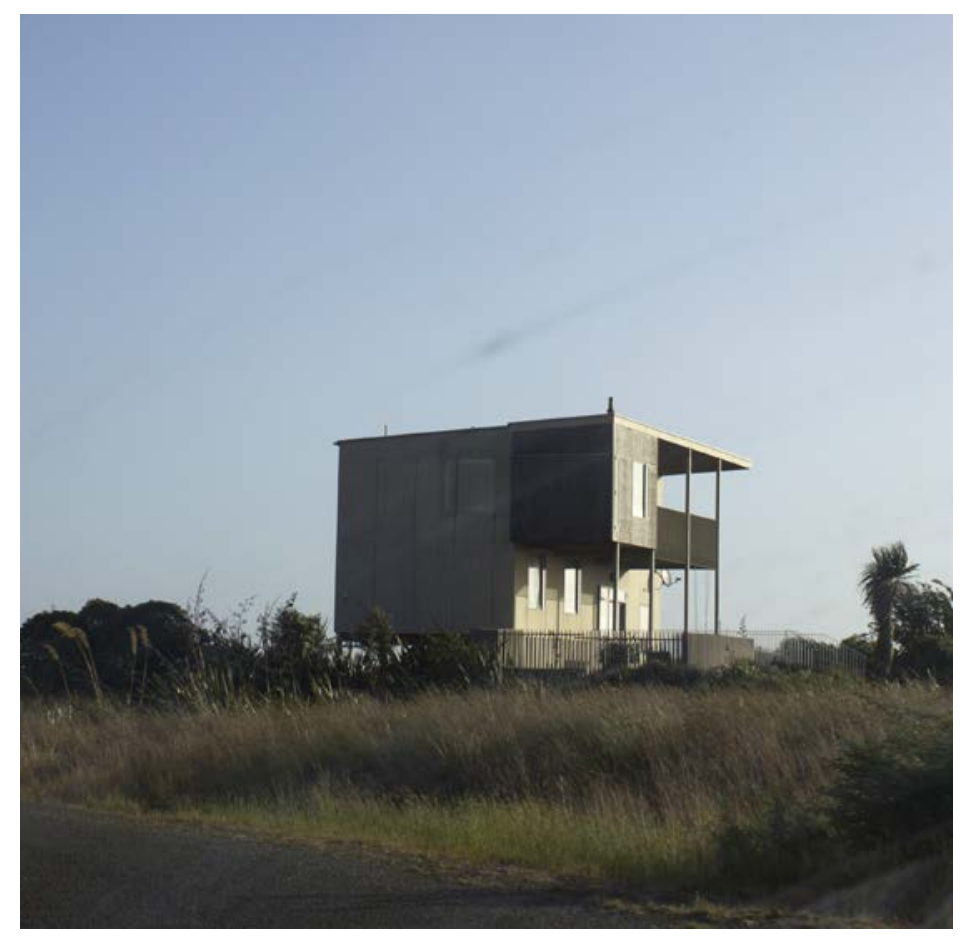

Fig. 39 Many of the beach houses and lifestyle blocks are situated on large, almost empty lots. 


\subsection{THE LIFESTYLE BLOCK \\ NEW ZEALAND AND COUNTRY LIVING}

Lifestyle blocks have become increasingly popular within New Zealand's rural landscape. The Real Estate Institution of New Zealand reports that the value of lifestyle properties sold has hit a new record high in 2015 at $\$ 6.026$ billion dollars (Stuff). The increasing number of lifestyle landowners is likely to have a significant impact on both land-use and land management. Policies and government agencies have typically targeted commercial farmers when promoting conservation and enhancement of the natural landscape. However, little attention is paid to engaging lifestyle landowners in such practices (Polyakov et al. 160). While policies focus on restricting farming practices, lifestyle blocks are able to neglect conservation values, despite having the potential to make a notable difference. 


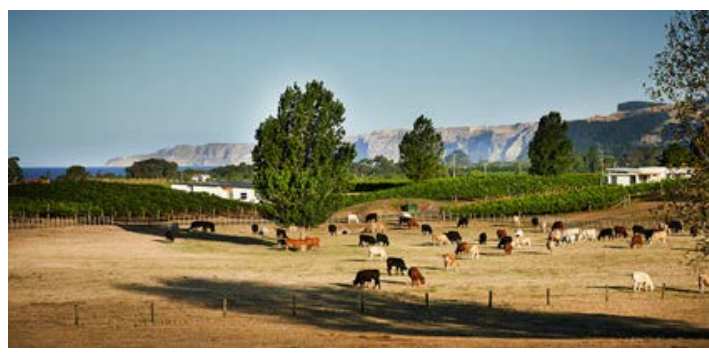

Fig. 40 Large areas are allocated for farmland.

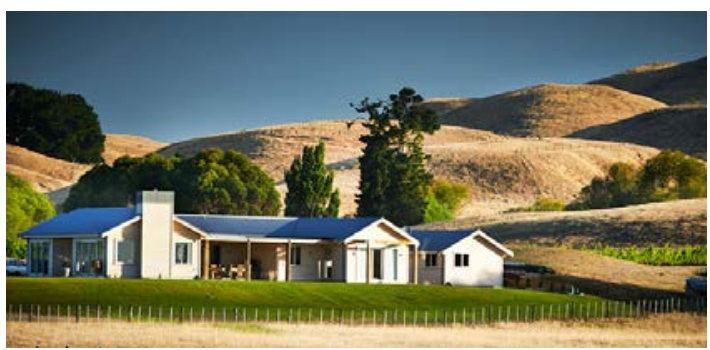

Fig. 41 Fences only block off pastoral areas, rather than outlining residential properties.

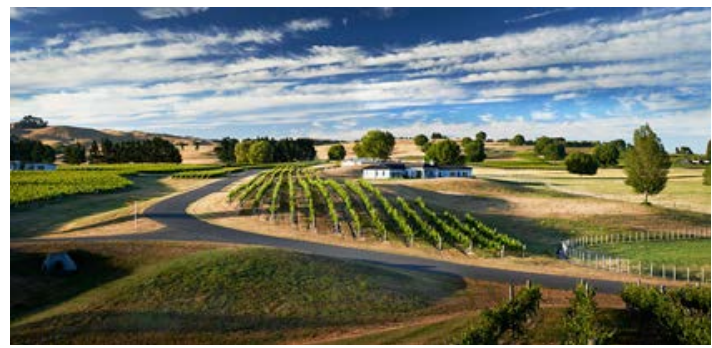

Fig. 42 Housing sits within the farmland.

\section{CASE STUDY}

\section{PARKHILL FARM, HAWKES BAY}

Parkhill Farm has been a key precedent in determining a new trend in lifestyle blocks and their ownership and management systems. It is a rural residential estate set within 72 hectares of pastoral farm and vineyards, with home sites ranging from $2500 \mathrm{~m}^{2}$ to $7000 \mathrm{~m}^{2}$. The subdivision is an example of a successful model integrating lifestyle blocks within a working farm.

The design acknowledges the need for a balance between productive land and residential, clustering housing together to maximise the land available for farming. This recognises that residents are vying for smaller plots within the rural environment, in order to have the lifestyle without typical high levels of maintenance. To achieve this, the farm and vineyard are maintained and managed by a private entity, but fully accessible to the residents. Residents pay an annual levy for the maintenance of roads, swales, common areas and the walking trails.

Parkhill Farm Ltd also formed the Parkhill Farm Design Committee to ensure a high standard of planning and design. Formed with representatives from the initial designers, the committee created a set of guidelines for both architecture and landscape in order to control design within the private properties. 
Residential Plots

Private Property

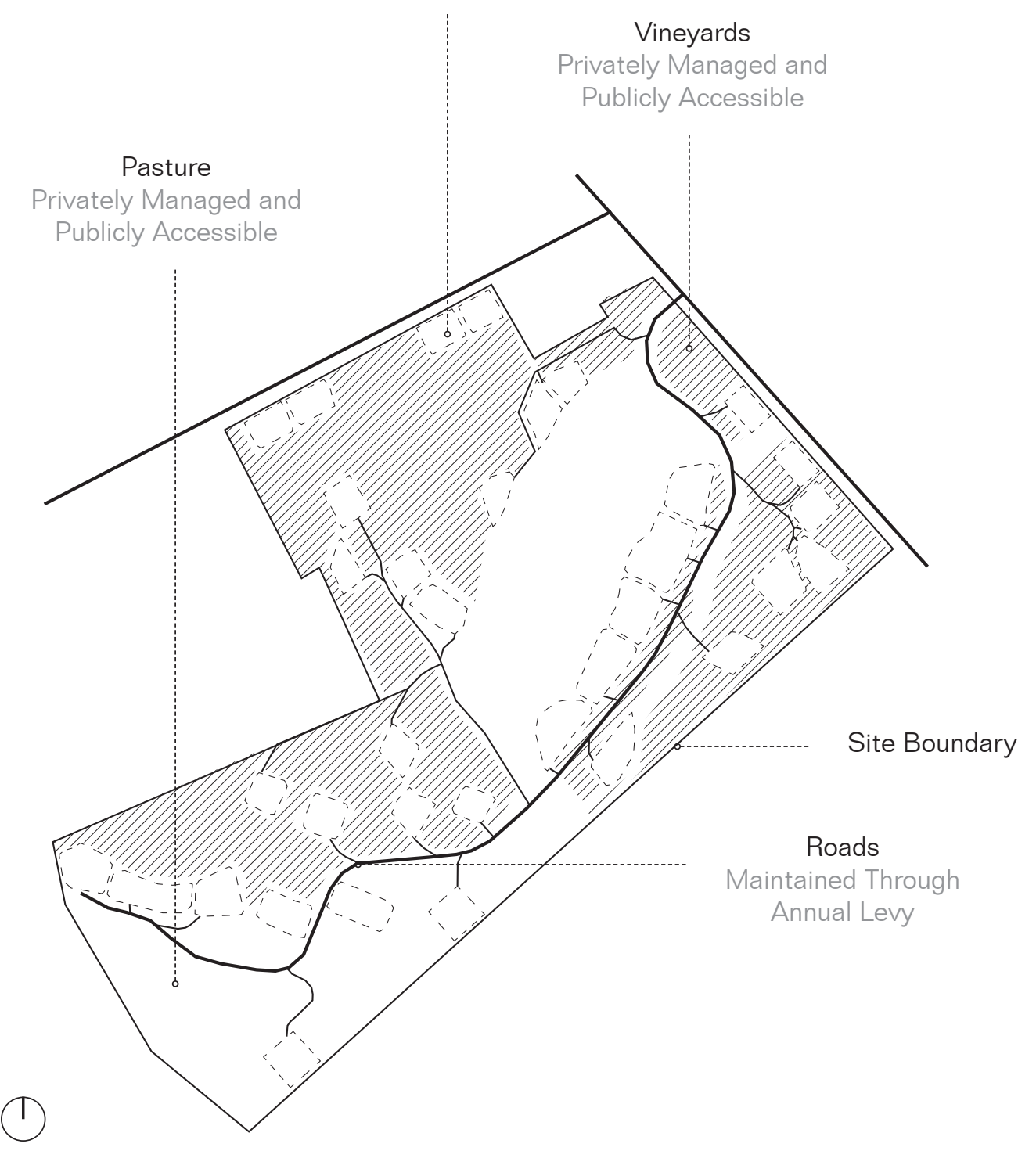

Fig. 43 Diagram of site plan and management of Parkhill Farm. 



\section{THE DESIGN}

Chapter Three

"Man's role historically has been destructive; today or tomorrow it can be totally, and for all life existent, irrevocably destructive"

lan McHarg - Man and the Environment 


\subsection{PROJECT OVERVIEW}

The project proposes a new residential development on the northern end of Peka Peka. It is partially situated on the site projected for the extension of the Tasman Lakes Development, that was rejected due to environmental concerns. It is prime real estate and fast-growing community of Peka Peka means there is a large amount of pressure for this coastal area to be developed. Waikanae has already spread in a similar manner, stretching along the coast and leaving the inland dunes for production.

However, this provides an opportunity for a development that is sympathetic to both the growing market and the landscape it sits within, unlike the slowly spreading suburbia of Waikanae. The swampy conditions of this coastal strip have too long been ignored, reducing the remnant wetlands to little more than backyard ponds.

This chapter is split into five sections (refer to fig. 44) which present the developed design. 


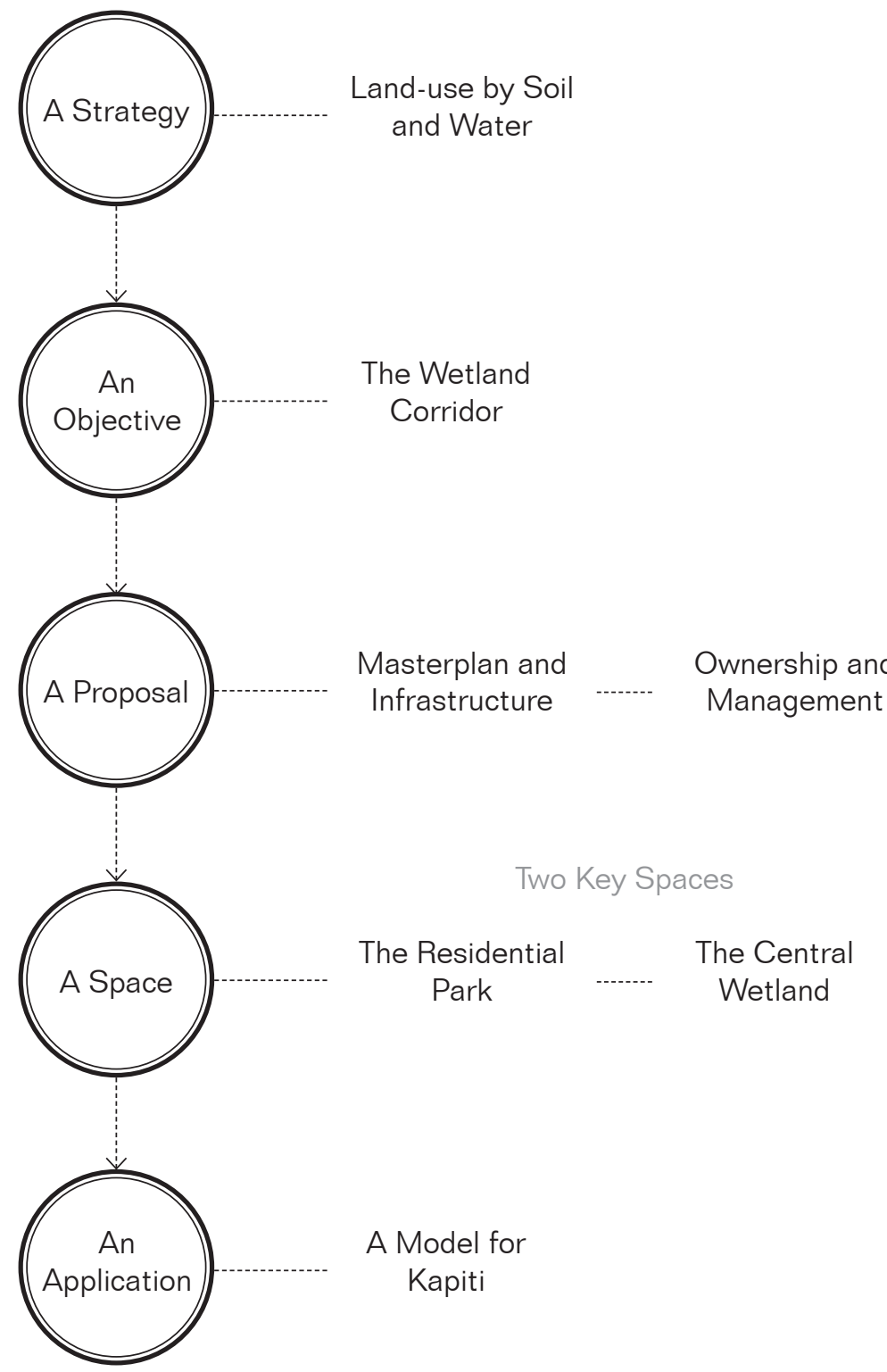

Fig. 44 Diagram of Chapter Structure. 


\subsection{A STRATEGY}

\section{DETERMINING LAND-USE BY SOIL AND WATER}

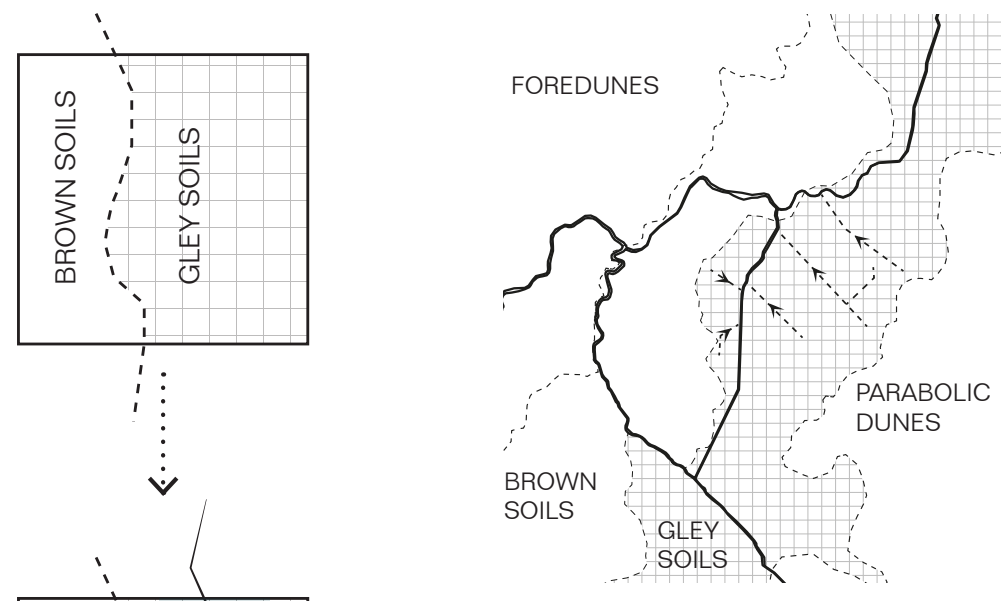

Fig. 46 Diagram of Site Conditions.
The first design move looks at determining land-use by the qualities of the land. Using soil and water to determine land-use minimises the input needed to optimise the land for a particular activity, for example, less groundworks or fertiliser. This strategy suggests to maximise use of the productive soils available and allocate less productive soils with regenerative bush and residential development.

There are two main soil types within the site, brown soils and

gley soils, and these are divided through the centre of the site. The peaty gley soils are highly productive for pasture and horticulture, but are required to be drained in order for this type of land-use to function successfully. Even though the site has an existing drain network, this is currently overflowing and flooding the pastoral land.

The dunes are also an important feature of the site. Development along the Kapiti Coast has typically ignored the importance of the foredunes in preventing coastal erosion and in sites where the foredunes have been preserved, it is imperative to protect them. The design proposes that no development will encroach onto the foredunes, using the both the foredunes and the parabolic dunes as limits of the site. 


\subsection{AN OBJECTIVE}

\section{ESTABLISHING A WETLAND CORRIDOR}

At a regional scale, the design works to restore and reconnect the remnant wetlands scattered across the coast. It acts as a model which can be applied to the rest of Kapiti Coast in order to create a wetland corridor that will run parallel to the coast, recreating the historic landscape in a new, modern context. This would include working with the existing drain network to establish new wetlands and vegetated swales. The corridor will help to increase biodiversity, propagate new bird habitats, reduce the effects of flooding and increase the quality of the groundwater.

It will also contrast to the current biodiversity proposal of the Kapiti

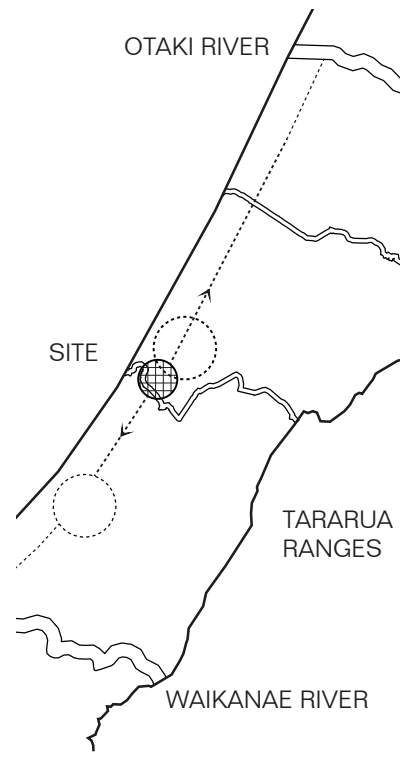

Fig. 47 Diagram of Ecological Corridors.
(1)
Coast District Council, which looks to strengthen the river and stream corridors. Working with the KCDC's proposal this will create a series of loops to create a cohesive biodiversity network along the coast.

It is proposed that this wetland corridor will also be established as a public right-of-way to introduce a recreational route from the two main rivers, Waikanae and Otaki. This will help to connect people back to this landscape and promote a new layer of tourism within the region.

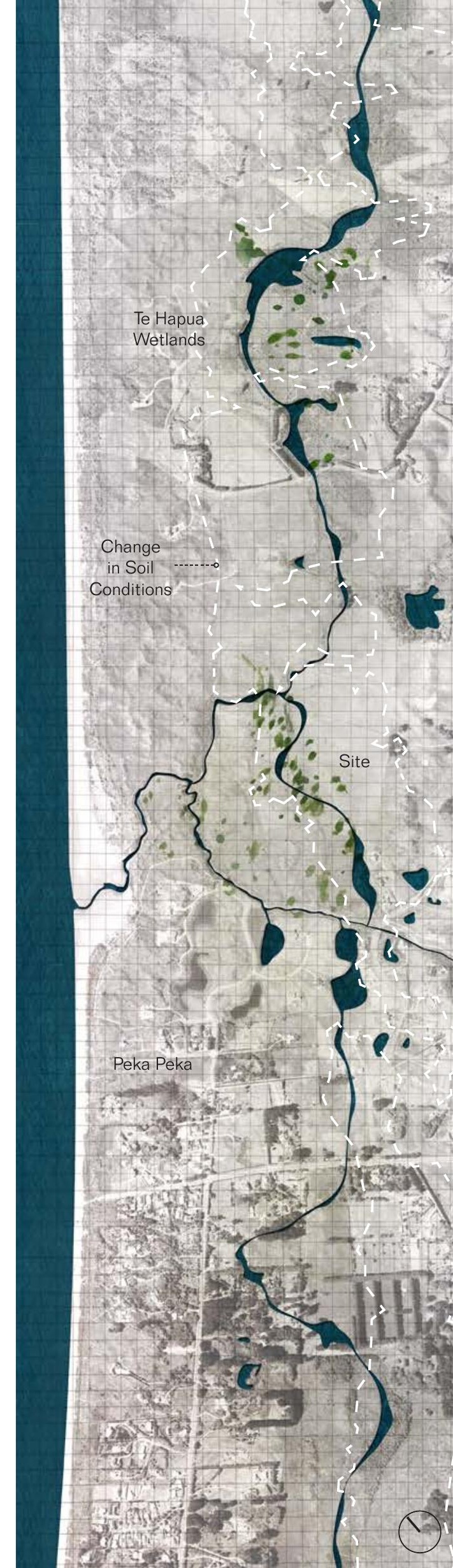




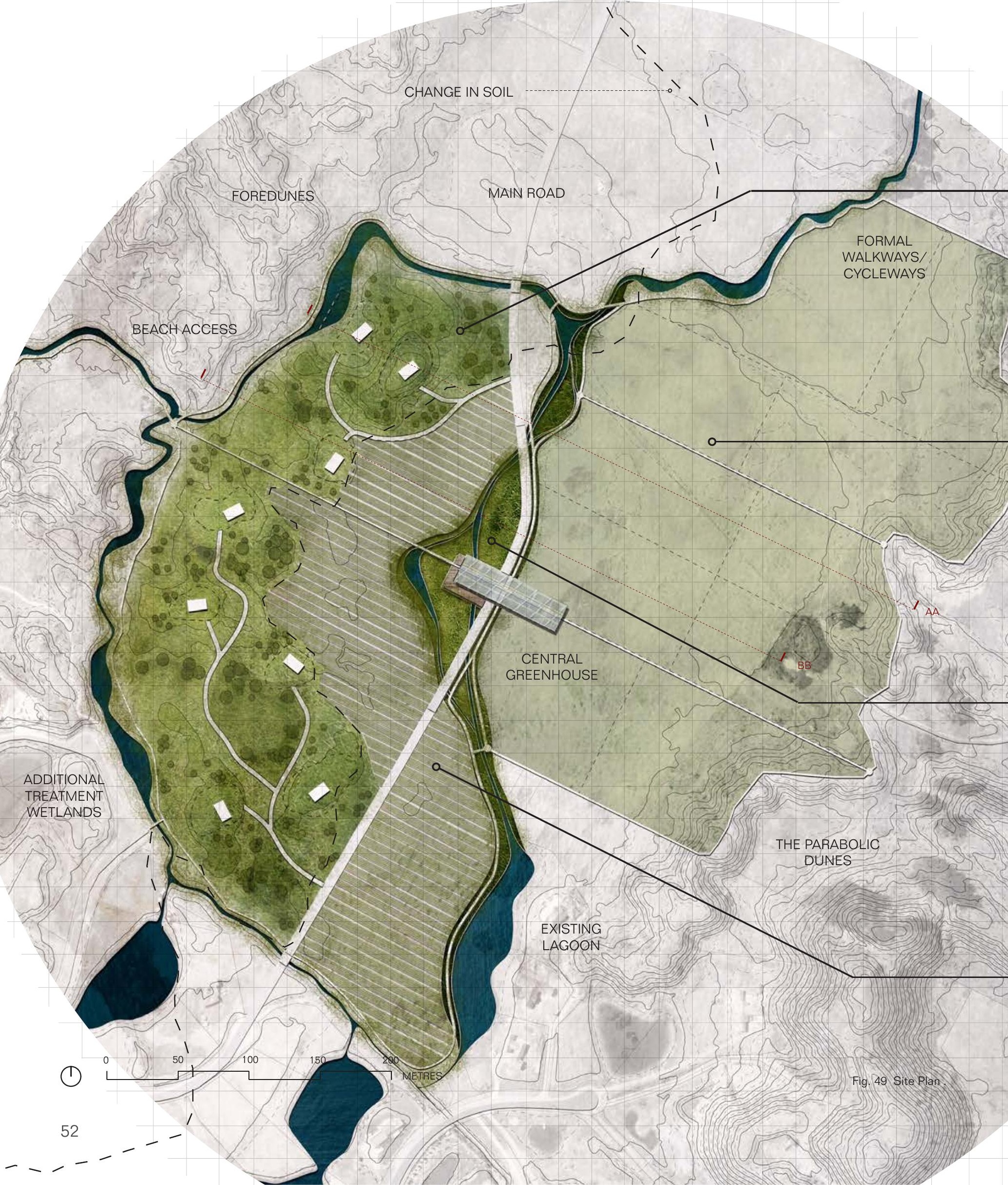




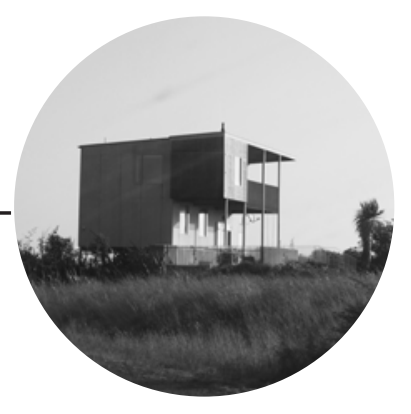

HOUSING AND REGENERATIVE BUSH

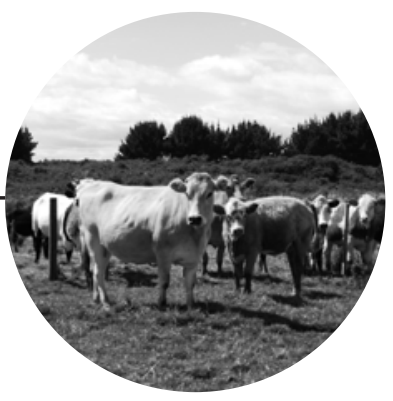

PASTURE

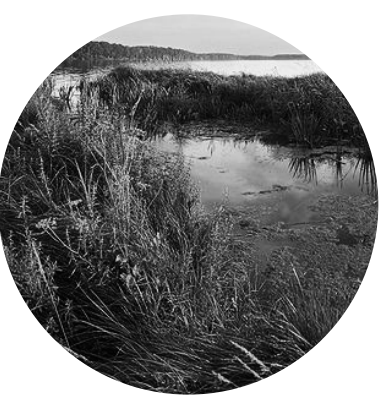

WETLANDS

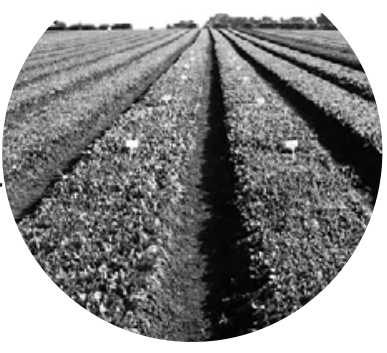

MARKET GARDENS

\subsection{A PROPOSAL \\ SITE PLAN}

Due to the soil conditions, the site is split into four key land-uses. Residential and regenerative bush is allocated to the brown soils, which are free-draining and less productive, whilst the productive land-uses, the pasture and market gardens, are allocated to the gley soils. The drain has been altered to incorporate a large overflow wetland, designed to increase the capacity of the drain during the flooding season. The pasture has been divided into ten paddocks at 1.3 hectares each to accommodate a rotational grazing system. As this is a more intensive method of livestock farming, the wetlands work to treat the run-off before it joins the stream. There is also a formal pathway network that runs throughout the site. 

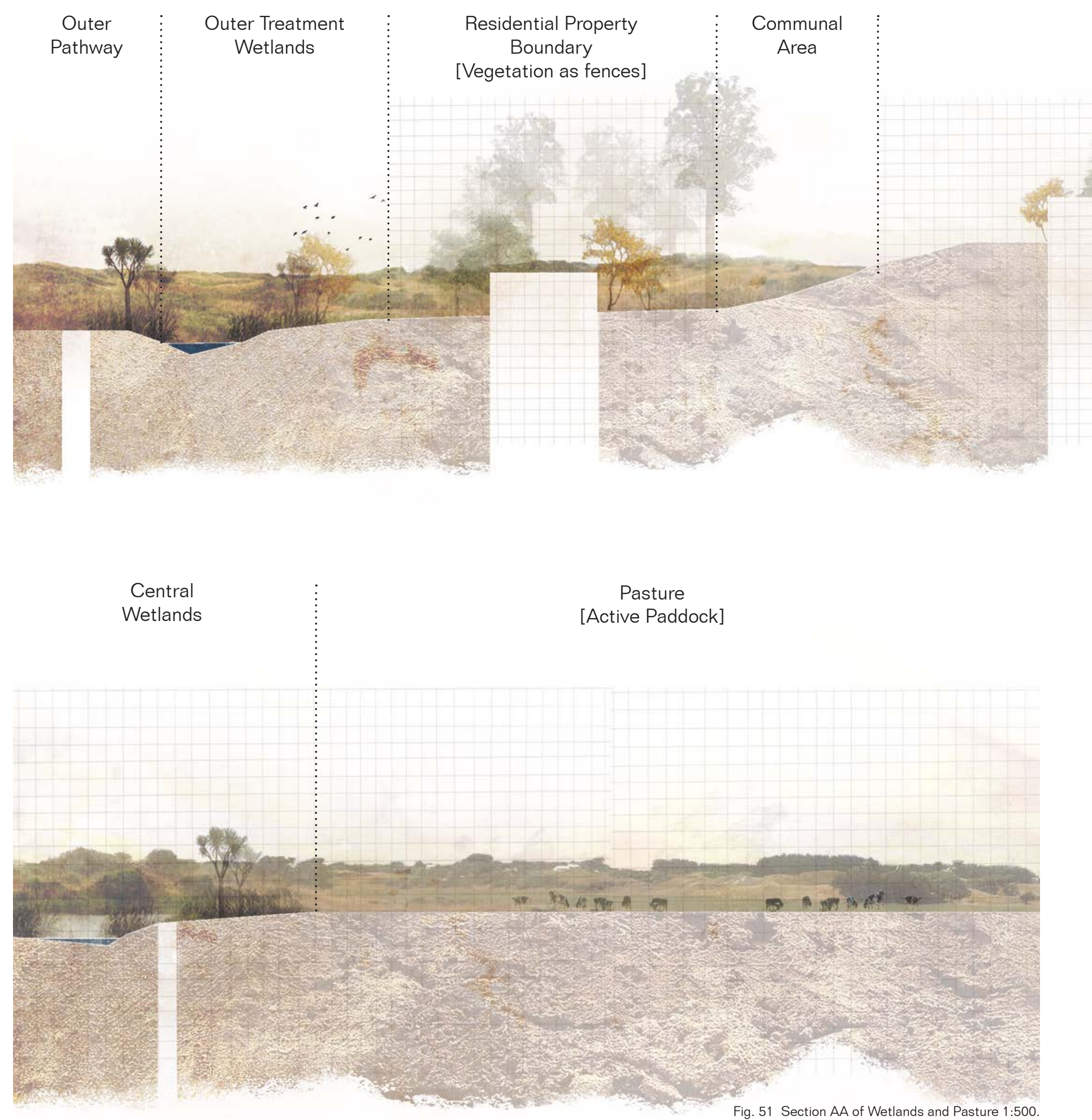


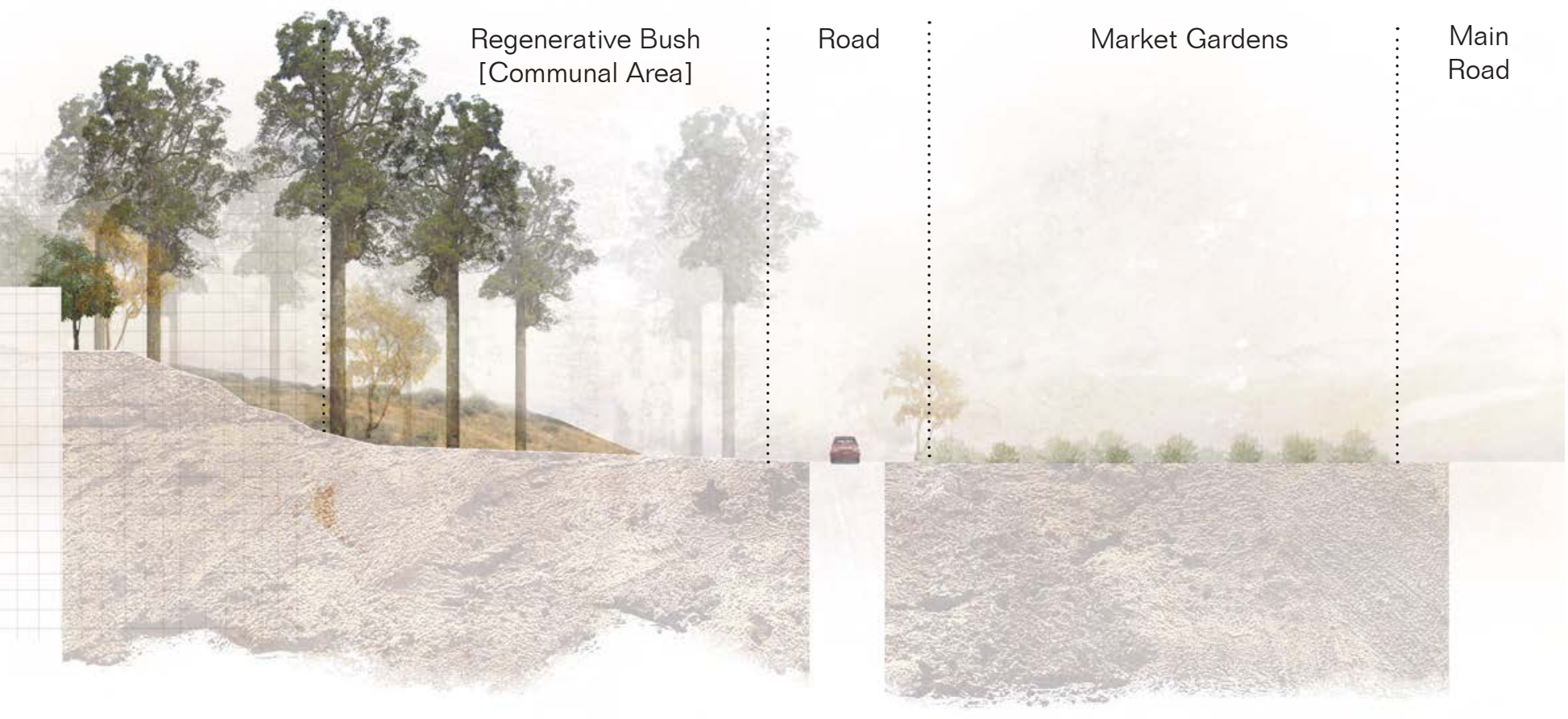

Fig. 50 Section AA of Residential Park and Market Gardens 1:500.

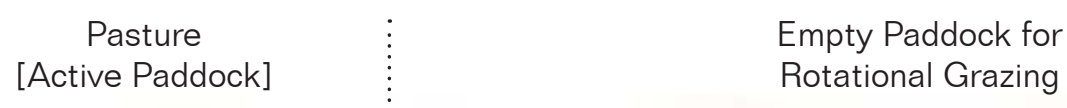

Rotational Grazing

Outer

Pathway

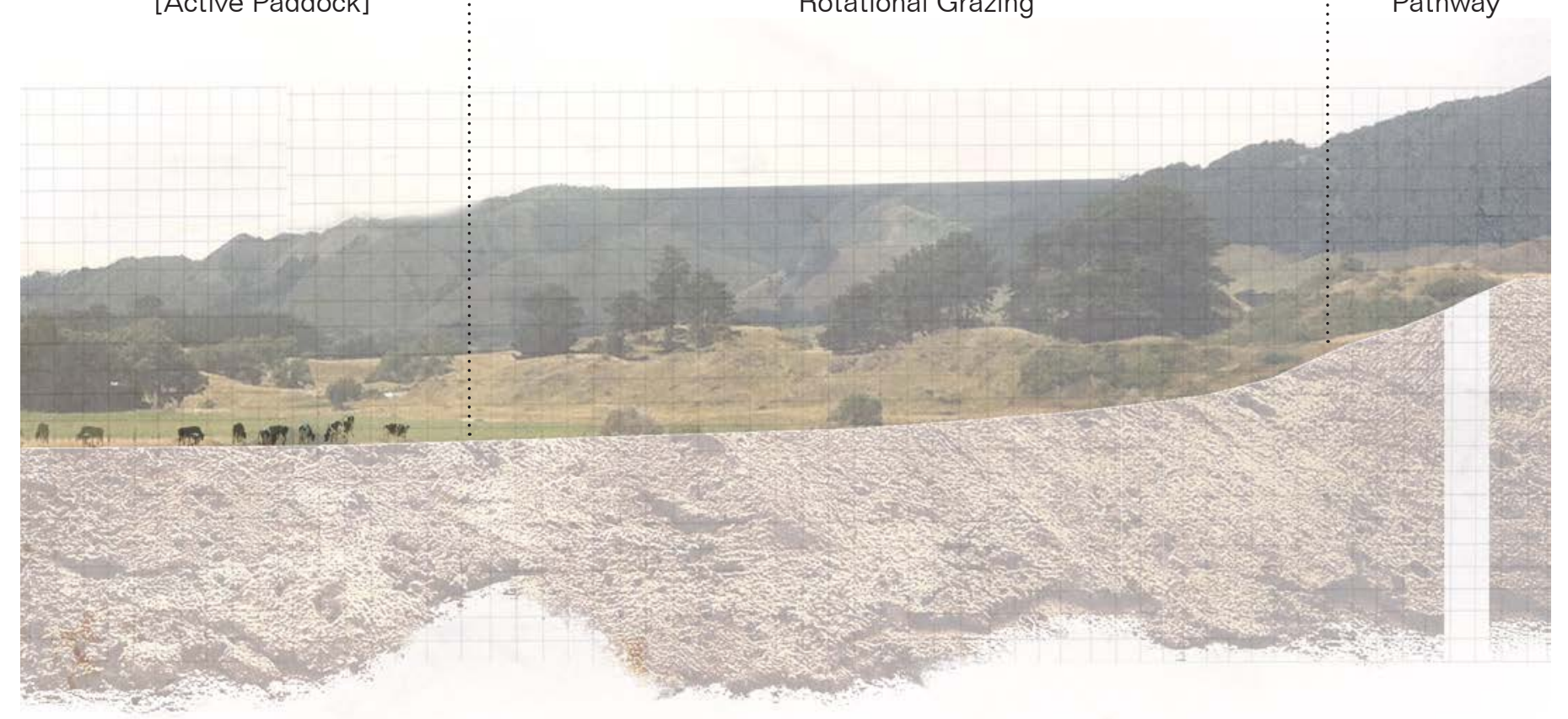

Fig. 52 Section AA of Pasture 1:500. 


\subsection{A PROPOSAL \\ RESIDENTIAL DEVELOPMENT = ECOLOGICAL DEVELOPMENT}

The value of ecology and biodiversity has always been difficult to gauge. Without a direct source of income, its value will always be underestimated. Relying on councils or a well-meaning community group to restore our landscape will not be enough to offset the damage that has been done. This is why it is imperative to integrate ecological systems into a residential setting, using the development of new lifestyle blocks as a tool to privately fund these investments in the landscape.

Within a residential setting, ecology can be used to enhance the value of land, providing dual benefits to both the environment and the residents. It increases amenity, provides recreation and promotes a healthier wellbeing. 
Escaping from the city is one of the primary reasons for residents to move to a rural environment and there are numerous studies that show the positive psychological and physiological effects of natural settings. Stephen Lau and Feng Yang discuss in The Journal of the Landscape Research Group that nature has undeniable restorative effects as natural settings meet the requirements for a restorative environment (56).

The incorporation of a working ecological system also helps to develop a sense of ownership over the land, therefore promoting a sense of responsibility towards it.

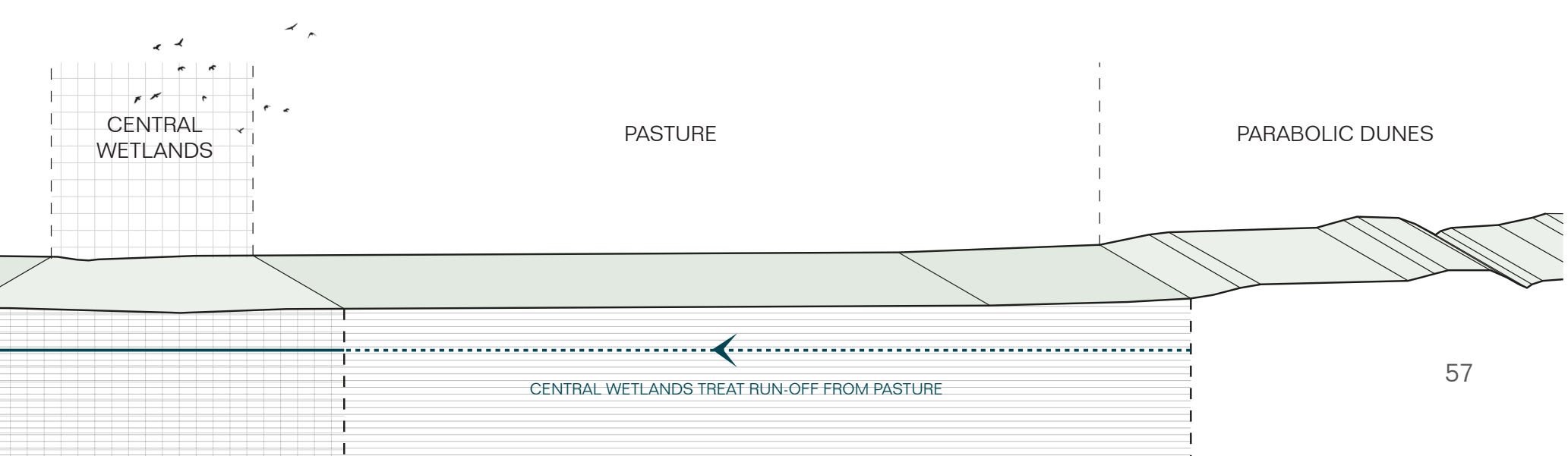




\subsection{A PROPOSAL}

\section{OWNERSHIP AND MANAGEMENT}

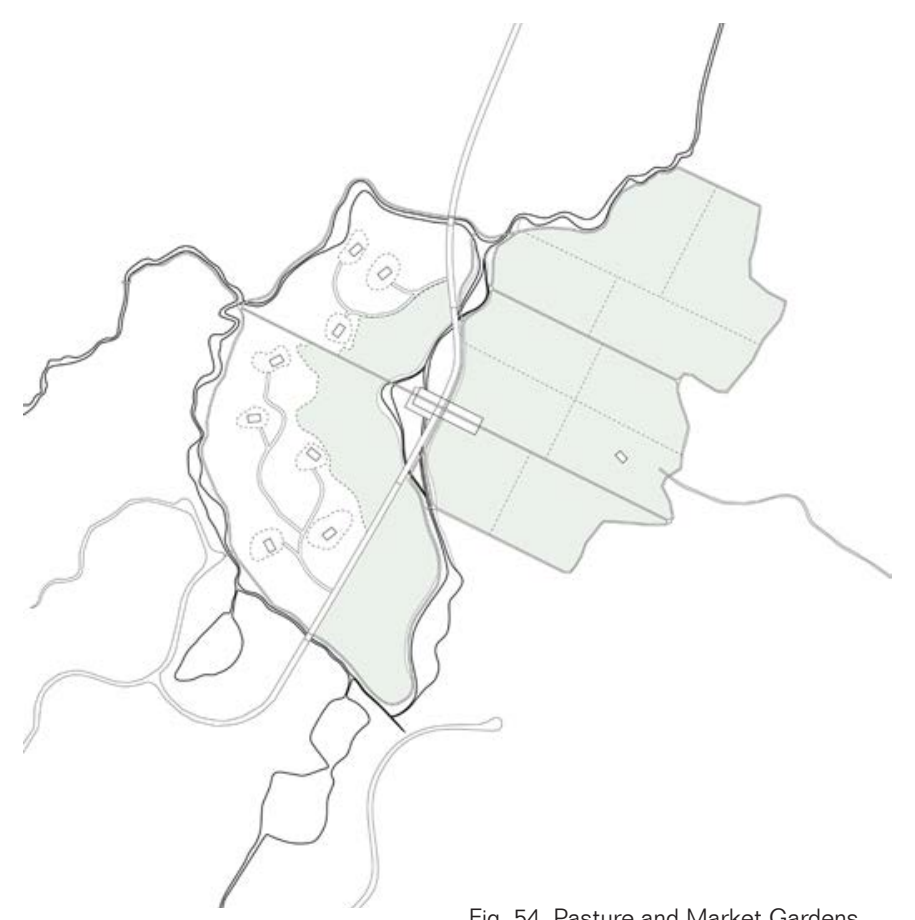

Fig. 54 Pasture and Market Gardens.

\section{PASTURE AND MARKET GARDENS}

Pasture and market gardens are leased to a private entity for management and maintenance. This reduces the residents responsibility for productive land and ensures it is used to its full potential.

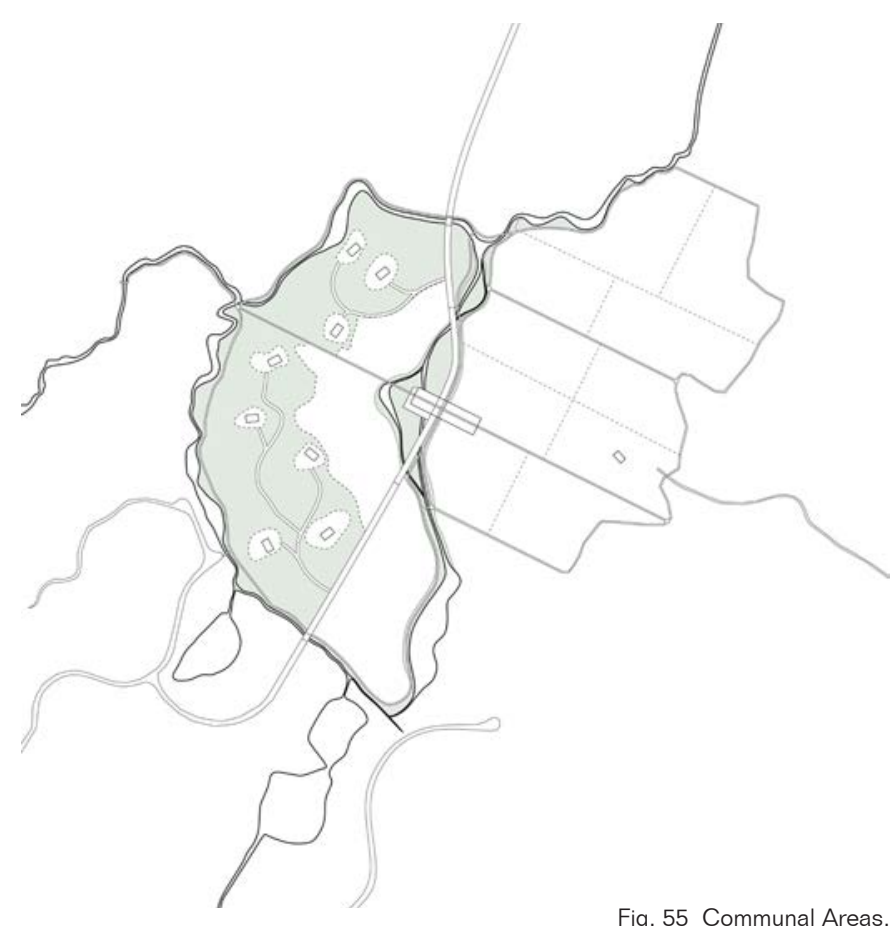

COMMUNAL AREAS

The majority of the leftover land is designated as communal areas for the residents use. The residents pay an annual levy for the maintenance of these communal areas. 


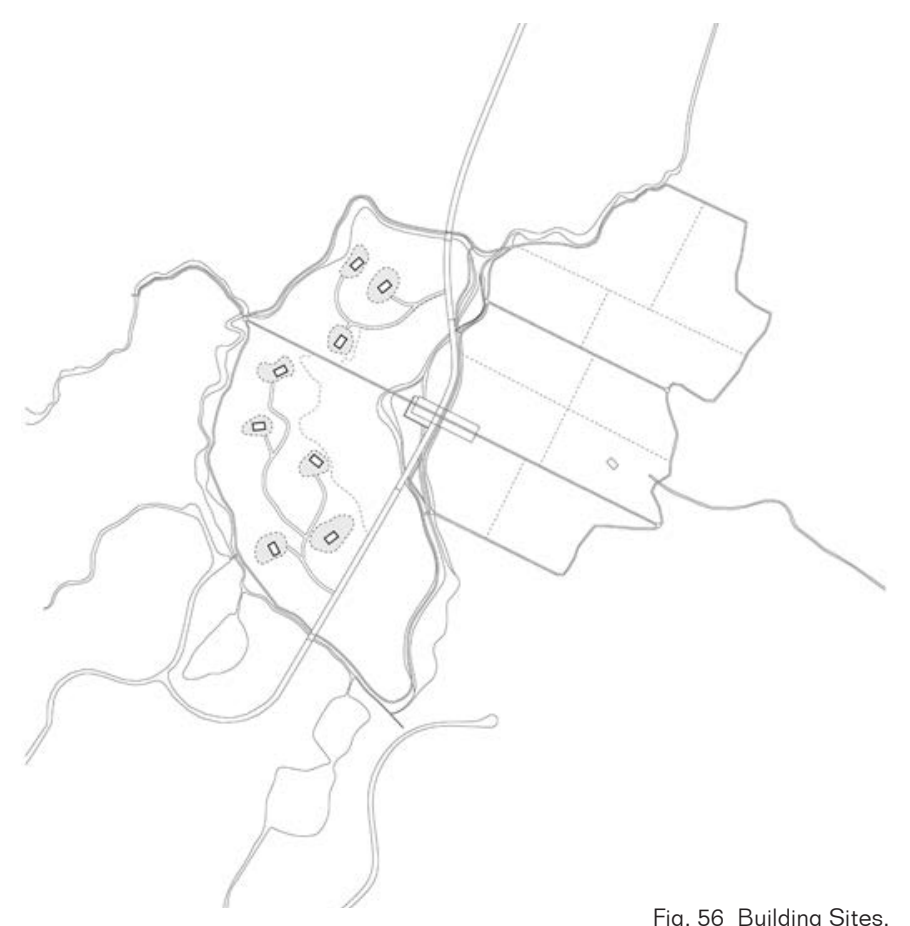

BUILDING SITES

Individual plots ranging from a quarter of an acre to half an acre are available for building and private use. The extents of these plots are determined by the topography.

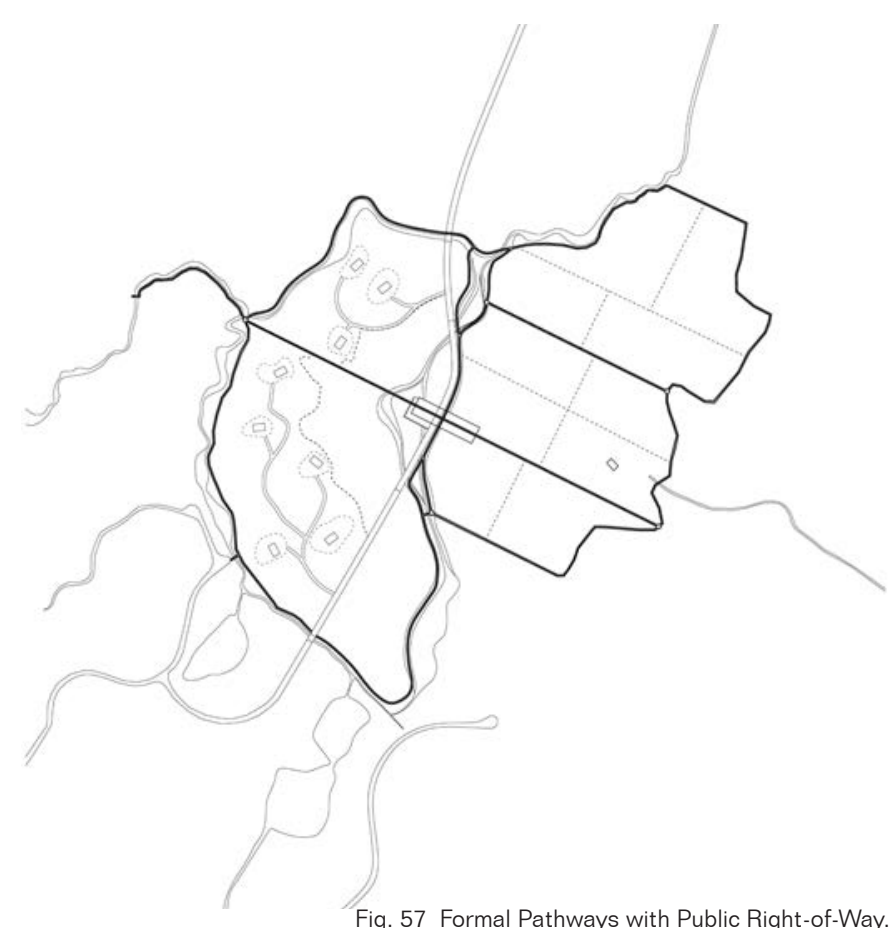

PUBLIC RIGHT-OF-WAY

All formal pathways are designated as public right-of-way for recreational use. This includes a walkway to the top of the dunes and beach access, as well as the central pathway through the wetlands. 


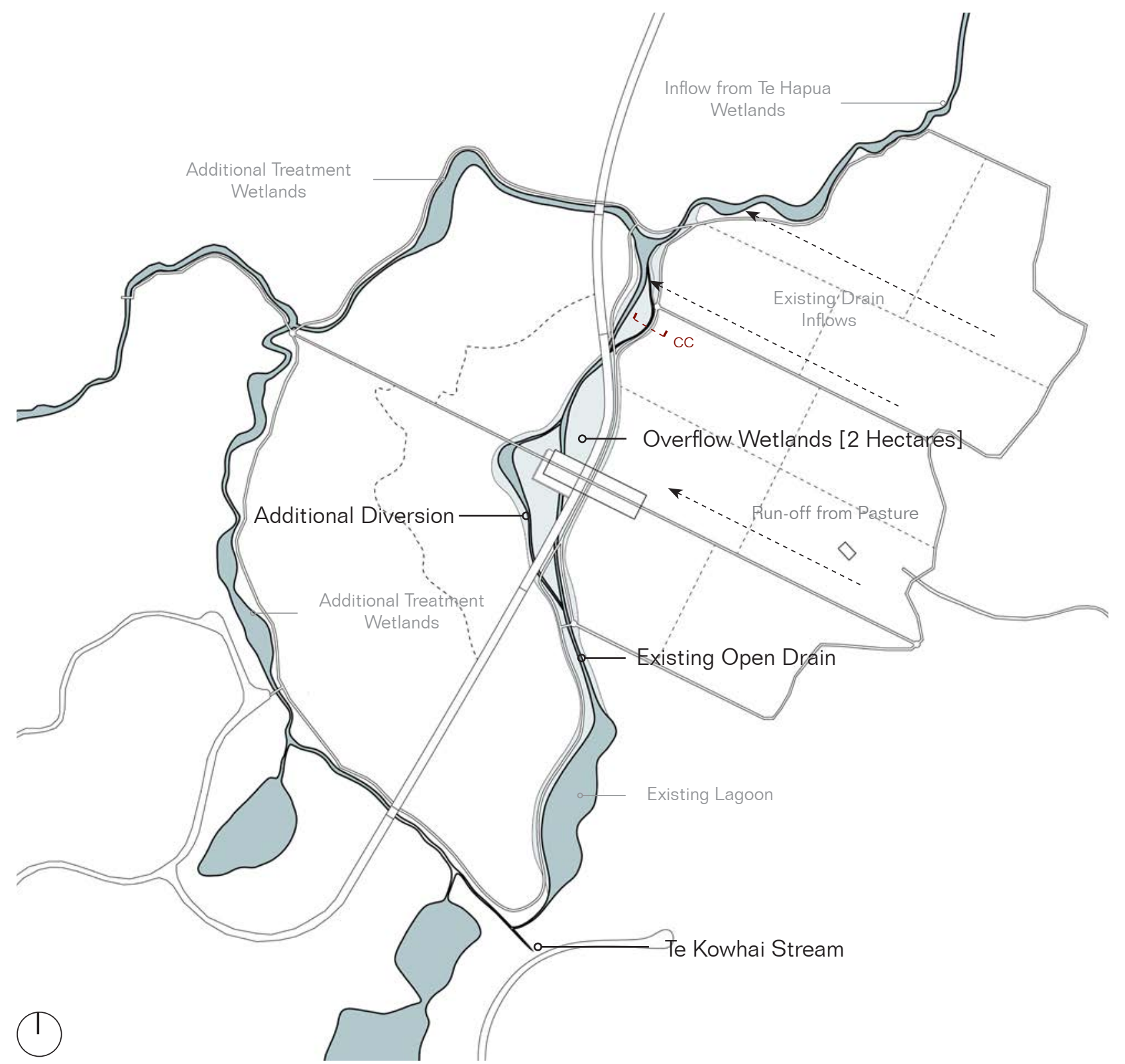

Fig. 58 Diagram of Wetland System. 


\subsection{A PROPOSAL}

\section{THE WETLAND SYSTEM}

There are two main changes to the existing stream and drain system; the addition of wetlands along the stream and the alteration of the central drain to accommodate for a larger flooding capacity. The additional wetlands along the stream work to treat run-off from sites upstream, while the overflow wetlands in the central system work to treat run-off from the site itself.

Within the central system, the existing drain is proposed to be expanded into a large wetland system which consists of an additional diversion and large amounts of harakeke planting. The harakeke works to treat run-off from the adjoining pasture and provide means for future production, as it is a traditional source of fibre.

The overflow wetlands would remain dry for the majority of the year, but provide a large area to flood during the wet season. This allows the pasture to function efficiently in the winter, even with the peaty soils.

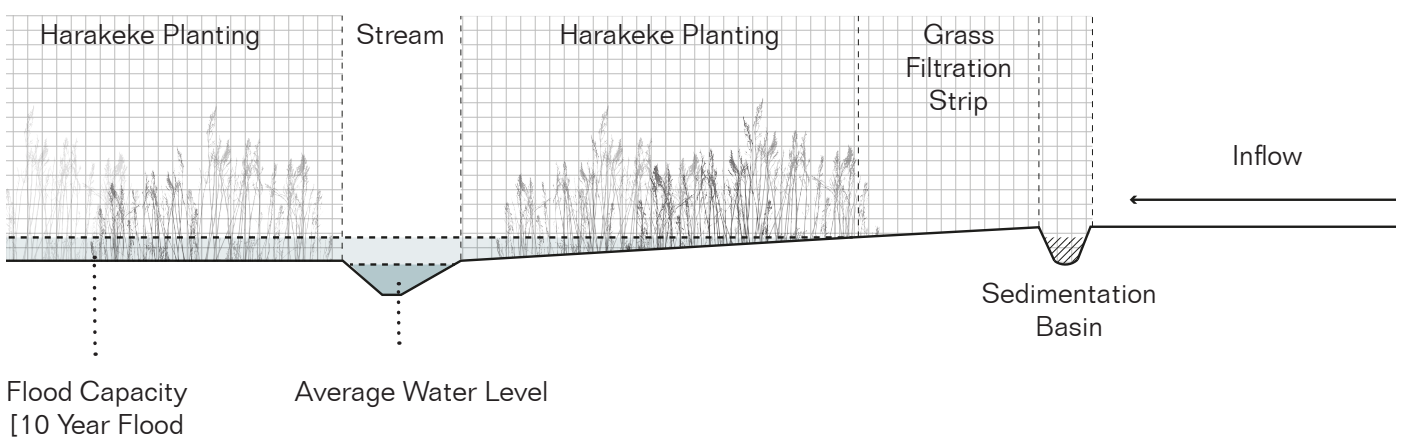

Fig. 59 Section CC of Central Treatment System for Agriculture Run-off. 


$$
\equiv
$$




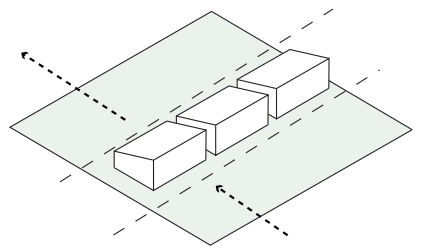

Clustered development causes a break in the corridor

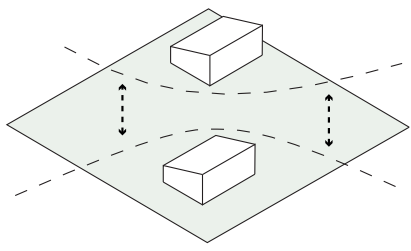

Higher densities create a larger edge effect

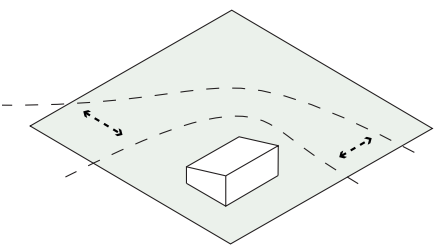

Singular placement of housing minimises the edge effect

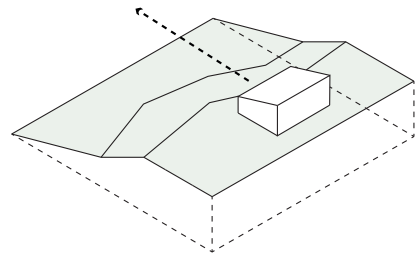

Placing houses predominately on raised areas to avoid 'wet feet' and maximise views to the ocean

\subsection{A PROPOSAL}

\section{HOUSING AND THE TOPOGRAPHY}

There were two key considerations for the placement of housing, adhering to the topography and minimising the edge effect. As the regenerative bush within the residential park is proposed as a genuine working habitat, these two factors were a crucial part of these design decisions. The majority of the houses are placed on raised areas of the site, overlooking the subtle depressions in the topography and maximising views towards other features of the site.

Fig. 61 Testing the Housing Placement. 


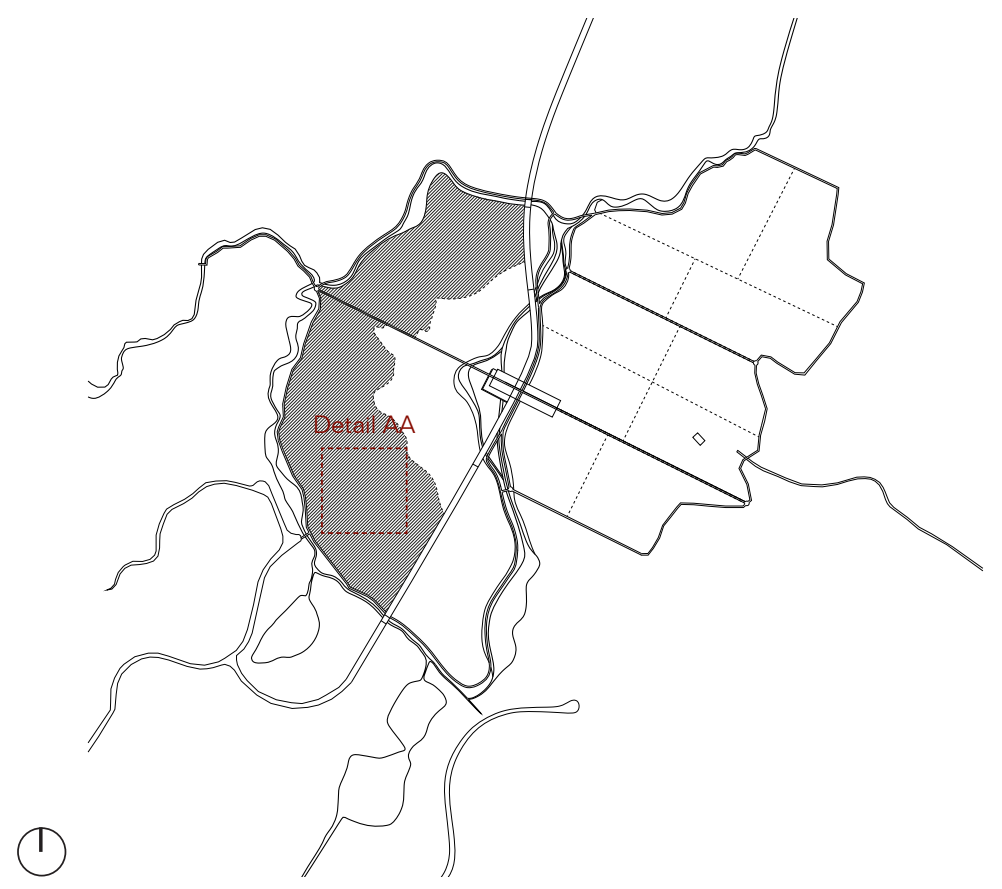

Fig. 62 Location of the residential park area.

\subsection{A SPACE}

\section{THE RESIDENTIAL PARK}

The residential park is a mixture of communal and private space, defined by the heavy regenerative bush and the glimpses of housing between. It focuses on the restoration of the past swamp forest, which largely featured kahikatea, a large slender tree which used to dominate wetlands and swampy areas. This area would propose a strict set of environmental guidelines, restricting the types of planting which could feature in both the communal and private land. This is becoming increasing common within New Zealand residential developments in order to ensure the planting of natives within the site. 


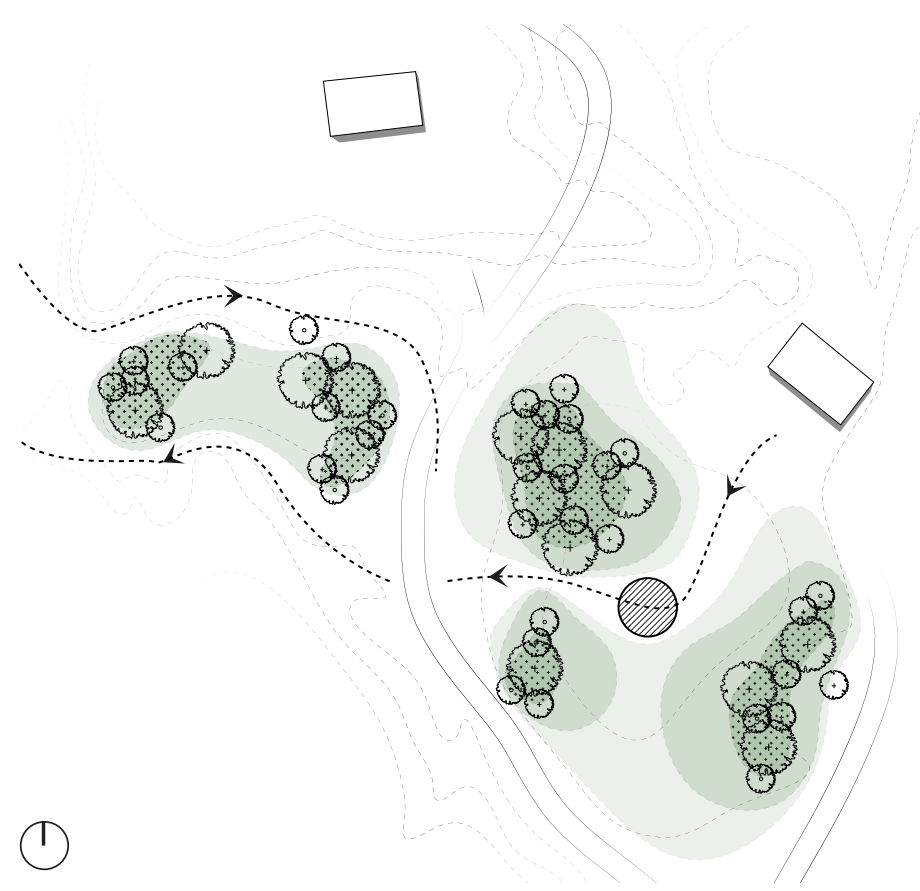

Fig. 63 Detail AA diagrams how planting adapts to the resident's use over time.

\section{A PLANTING STRATEGY}

As establishing a swamp forest would take a significant amount of time, a strategy is proposed to take advantage of this process. The strategy looks at initially planting in small groves throughout the site, leaving the residents with large amounts of open space. These groves are left to expand and seed organically throughout the site, eventually joining to create larger patches of vegetation. Areas with high levels of activity limit the growth of vegetation and areas enjoyed by the residents can be maintained to create a matrix of pathways and open space that is defined by the community. 
Groves are established with sturdier species

to protect the kahikatea in early stages

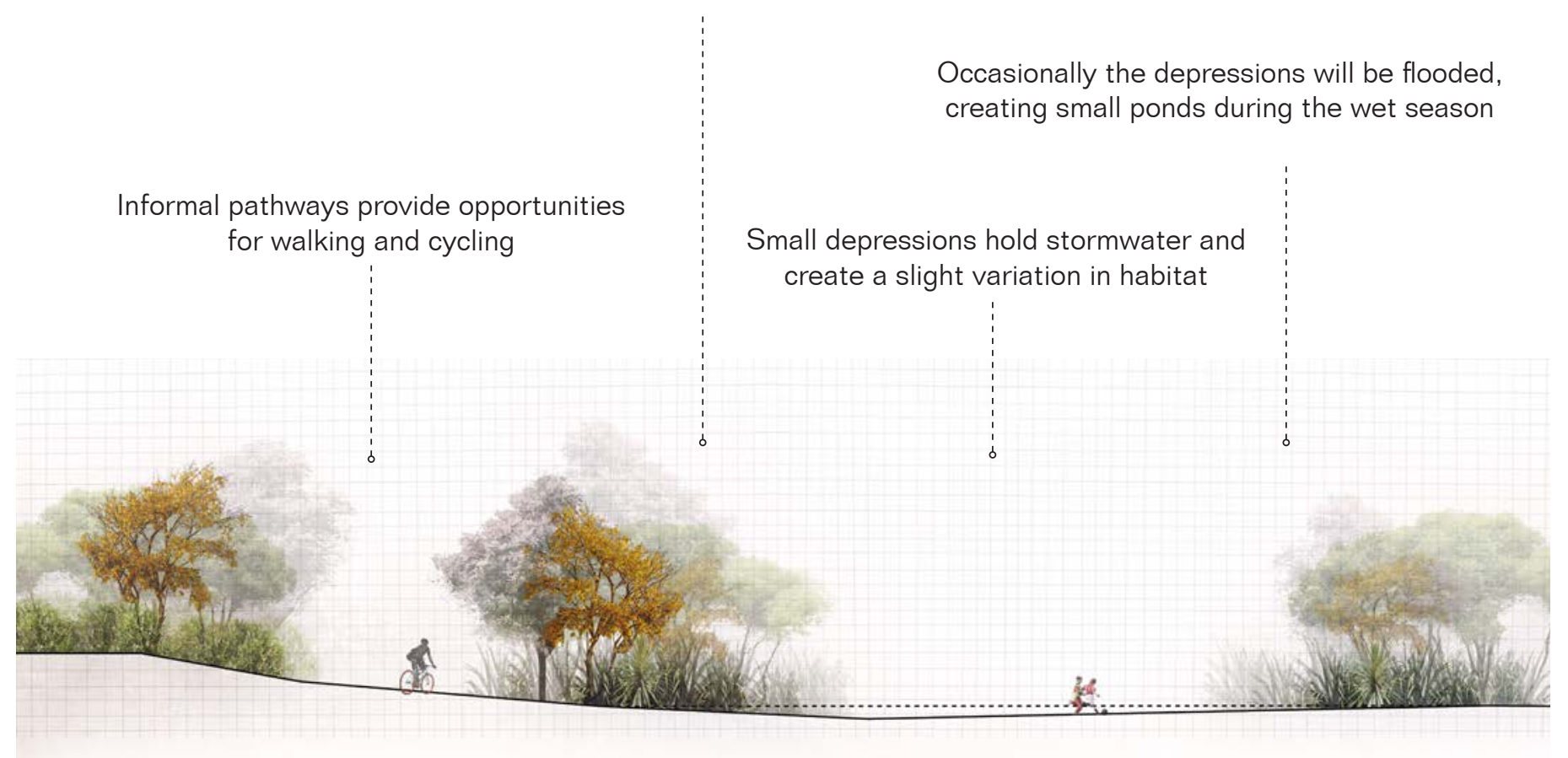

Establishing Groves of Planting

Fig. 64 Section of Planting with Initial Structure. 
The nature of the site will change gradually over time, attracting more birds and establishing a small forest on site

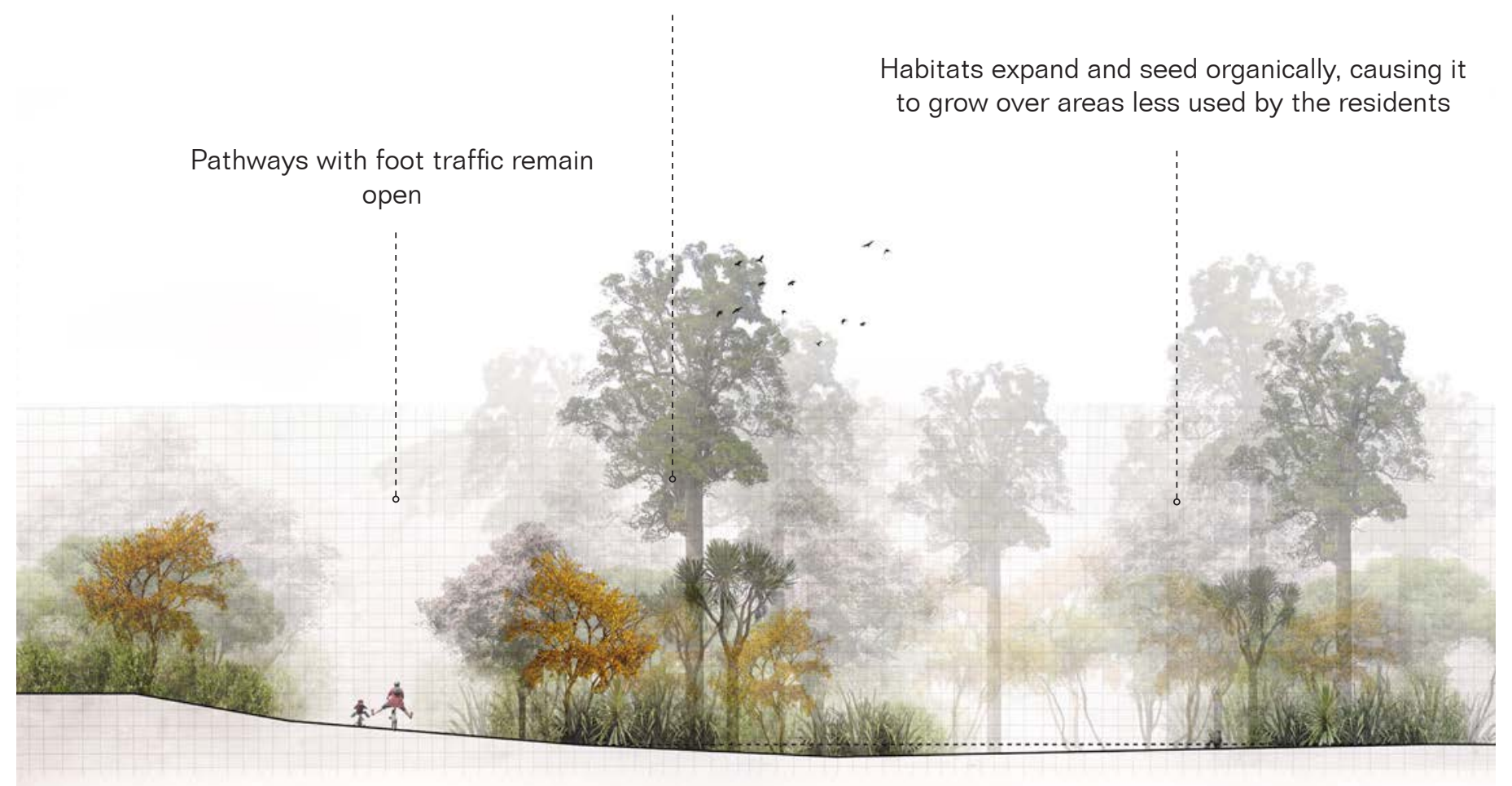

Established Planting at Maturity [25 Years +]

Fig. 65 Section of Planting with Matured Structure. 


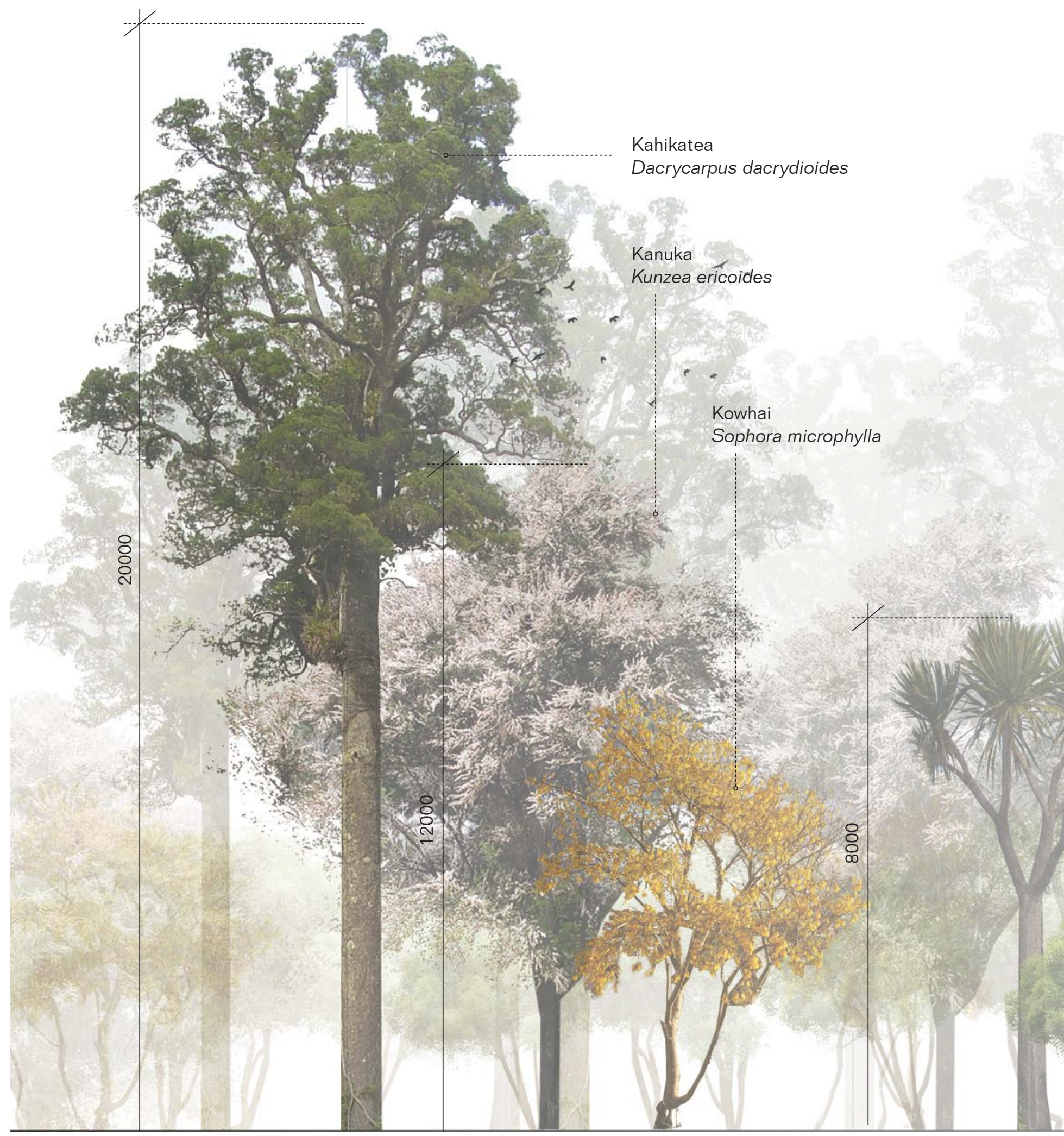




\section{KEY TREE SPECIES}

Figure 66 illustrates the physical qualities of the key tree species present within the design. Myoporum laetum and Kunzea ericoides were chosen primarily for their ability to establish quickly and resist salt winds, making them a suitable choice for succession. This will allow less hardy trees such as the Dacrycarpus dacrydioides to be nurtured in its early stages. Trees such as Cordyline australis and Sophora microphylla are common and well known New Zealand trees, evoking a sense of home and familiarity.

Cabbage Tree

Cordyline australis 


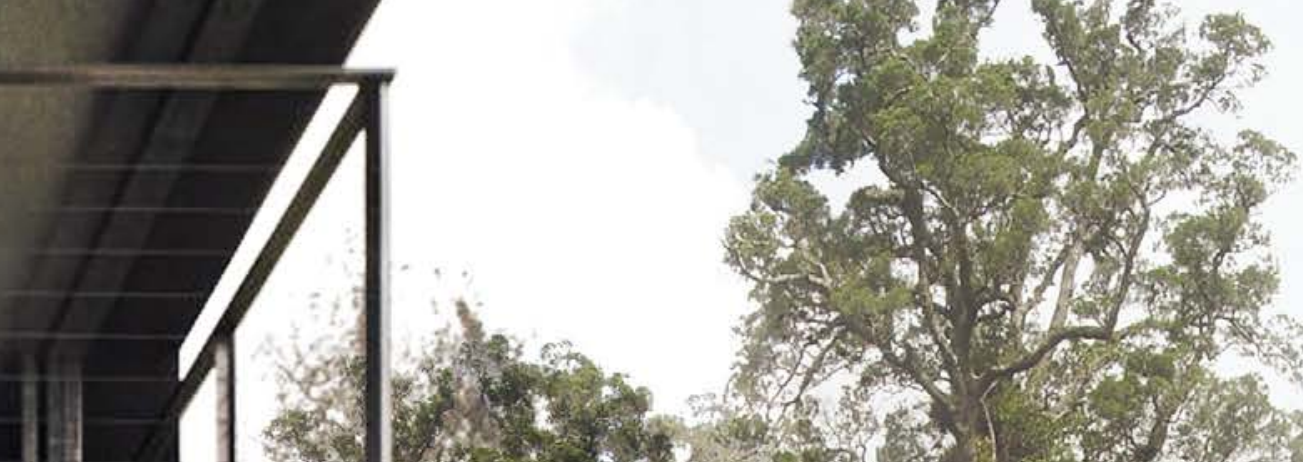




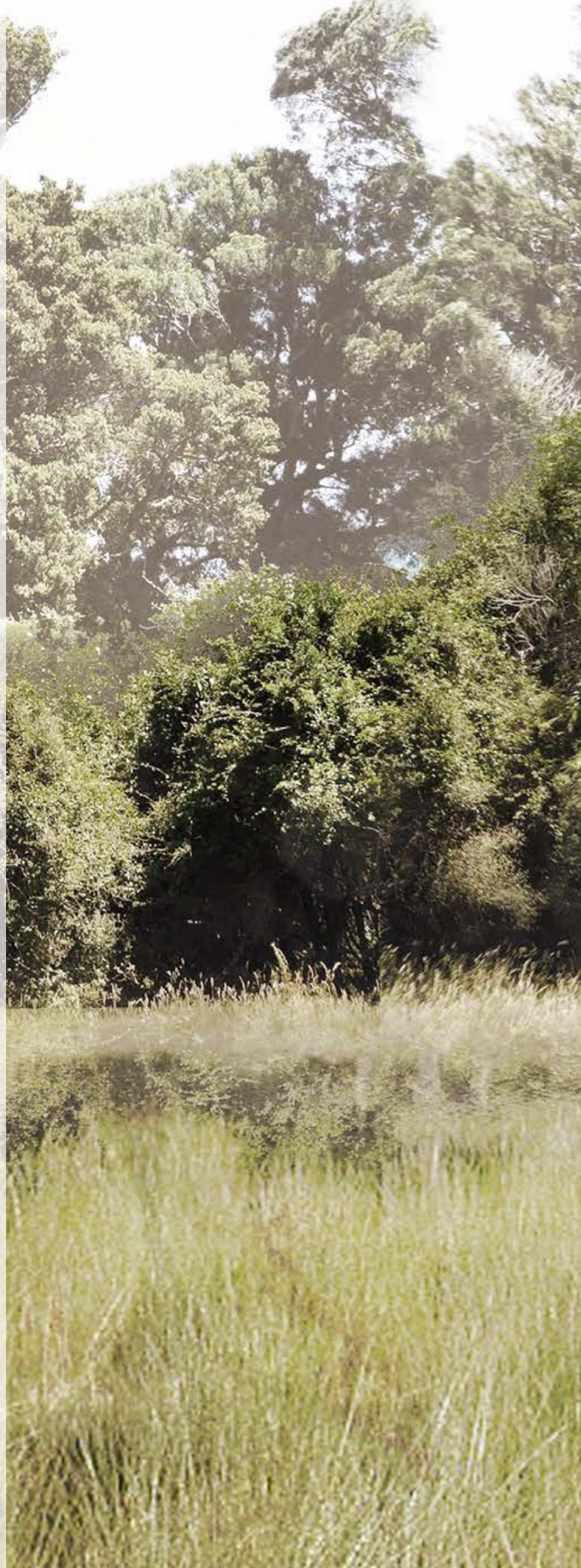




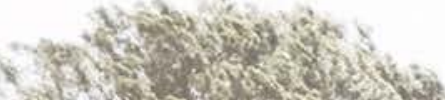

10.

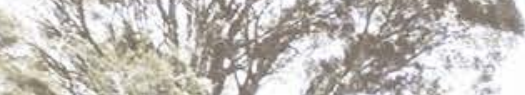

S. 7 ,

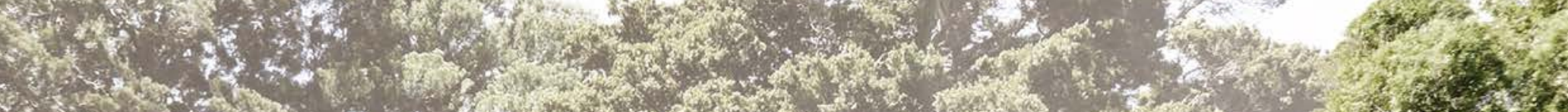

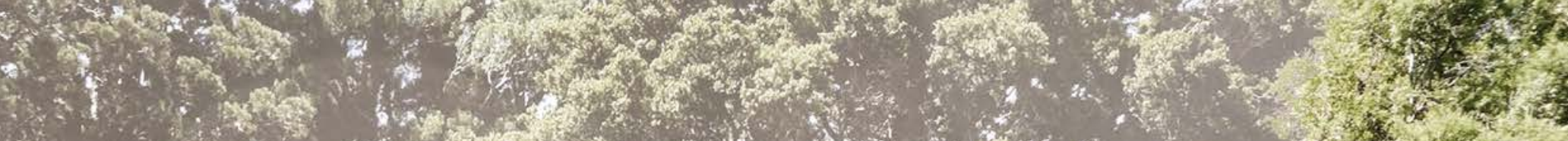
(2) cring $3+2+2+3$ .i.

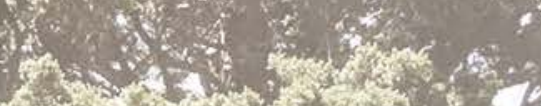

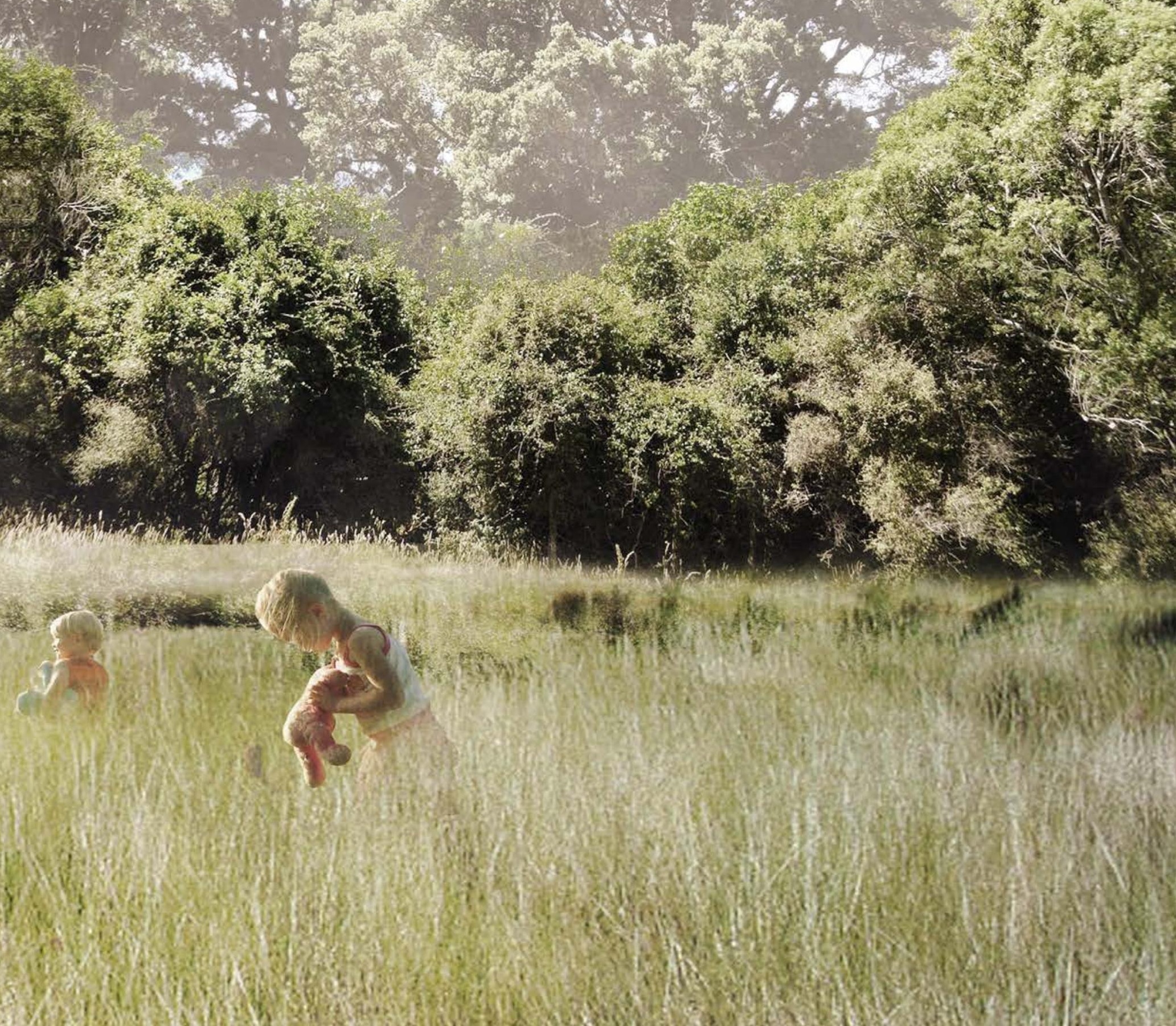




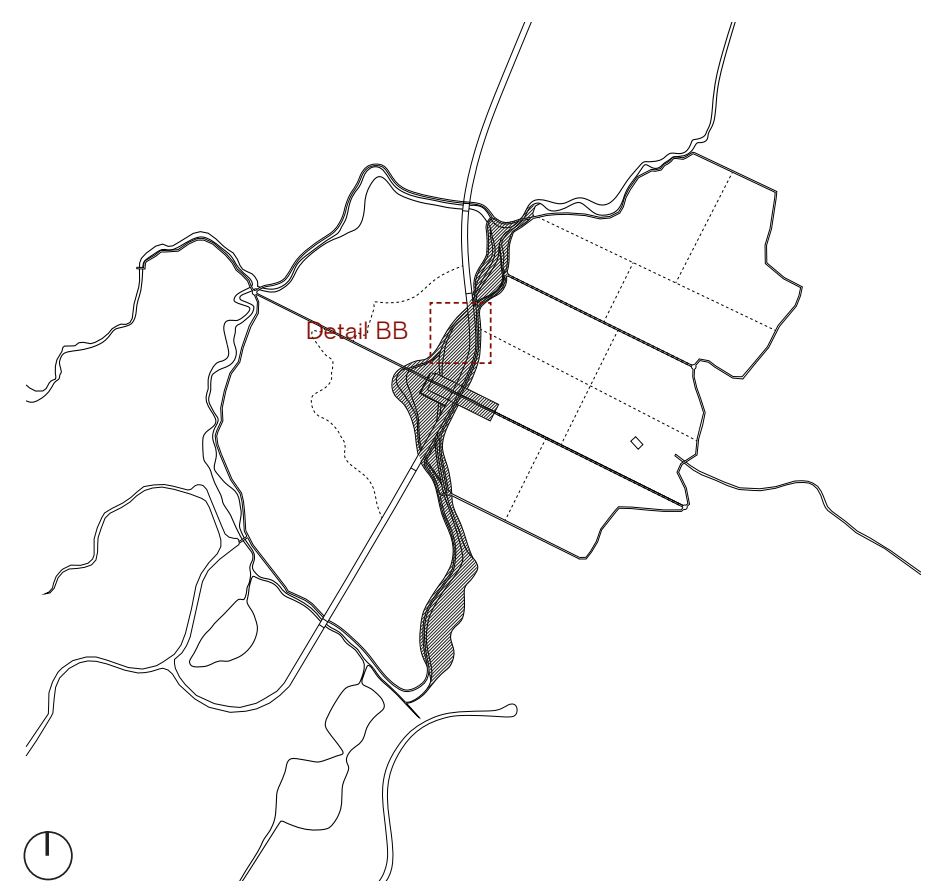

Fig. 69 Location of the central wetland system.

\subsection{A SPACE}

\section{THE CENTRAL WETLAND}

While the wetland's primary function deals with the control and treatment of water, the corresponding pathways and adjoining open space are an important recreational space within the design. These areas are designated as a public right-of-way, making the space the only area on site which is fully accessible to all visitors. Two pathways run parallel down either side of the drain, weaving in and out of the wetland, along with the main road. A greenhouse is also proposed on the edge of the wetland as an extension of the market gardens. This greenhouse is envisioned as a meeting place, connecting the outer community, the farmers and the residents, as well as a centre to purchase local produce. 


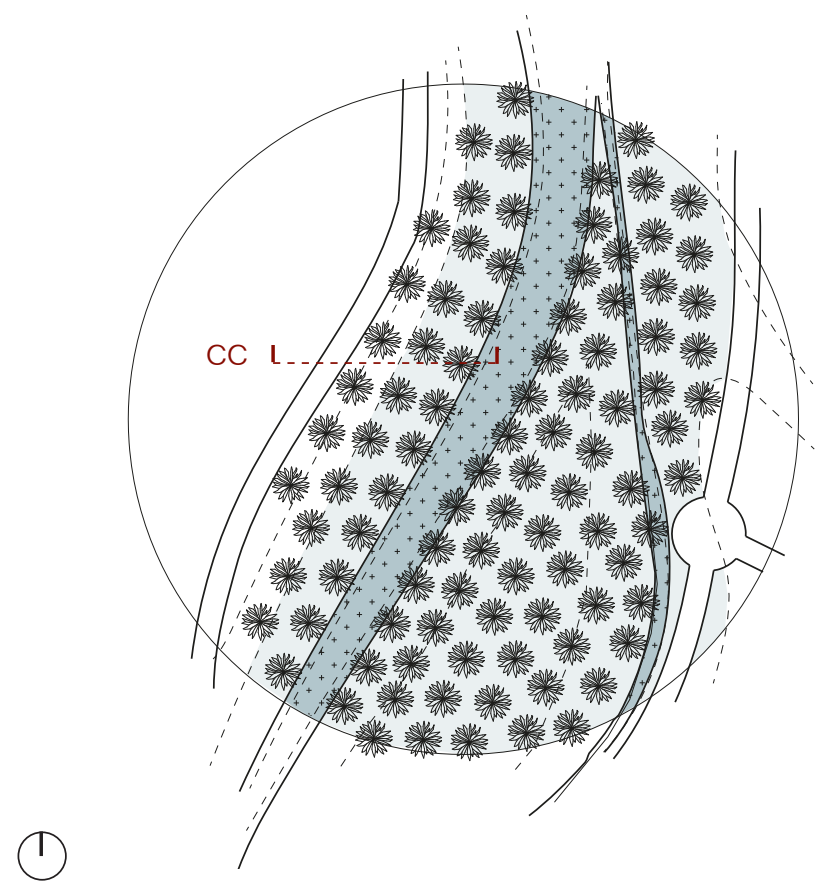

Fig. 70 Detail BB shows a zoomed plan of wetlands 1:800.

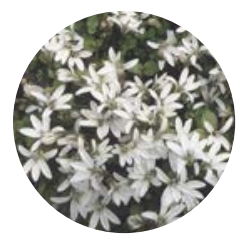

Fig. 71 Pratia angulata.

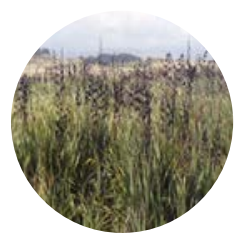

Fig. 72 Phormium tenax.

\section{A PLANTING STRATEGY}

Two key species are proposed for the central wetland, Phormium tenax (harakeke) and Pratia angulata. The lack of diversity is due to the robust nature of both species and the potential income harakeke can bring as a possible source of fibre. The harakeke is placed with $2-4 m$ spacings to allow for harvest.

Pratia angulata is a groundcover with the ability to bloom underwater, producing pale, white flowers even during the rainy seasons. 
Boardwalk opens up along the pathway and allows visitors to interact with the wetland. This move also allows harakeke farmers to access and move more freely within the wetland without being restrained to the designated rows of planting

The boardwalk is designed to encourage interaction with the plants, allowing them to permeate through small gaps. The rails are titled slightly outwards allow users to

\section{walk is designed to encoura
s, allowing them to permeate
rails are titled slightly outwarc
lean into the space}

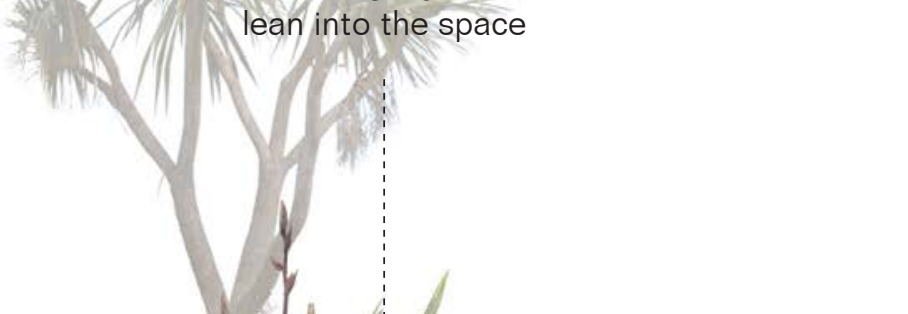




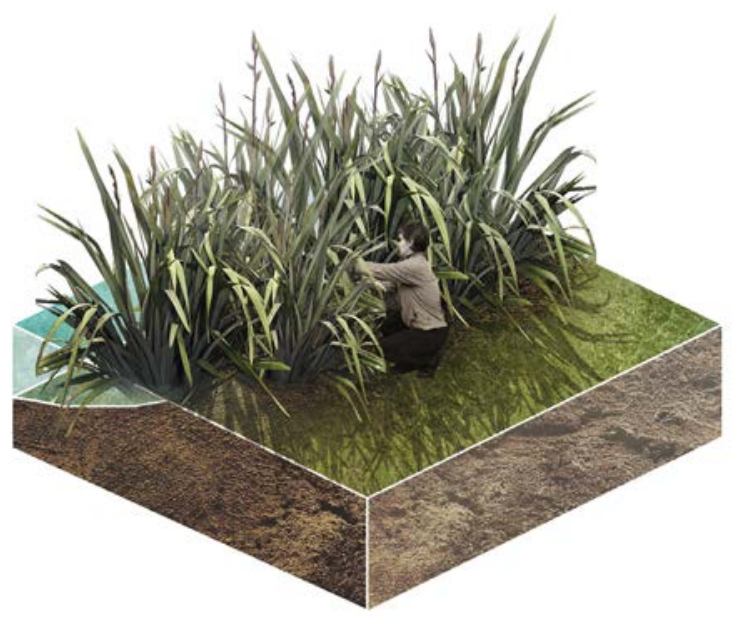

Fig. 74 Harakeke is traditionally farmed by hand, making it a labour intensive practice.

\section{HARAKEKE FARMING PROSPECTS}

Harakeke is an ancient and iconic New Zealand species. Fundamentally the large plantation within the design is established for environmental purposes, but it also provides secondary opportunities for harvest. Small blocks such as these can readily supply smaller niche markets; however, these blocks can also serve as a stepping stones for larger commercial plantations. Harakeke is primarily farmed for its fibre, which is a native alternative to linen, but its oils and gels can be found in a range of niche products in both culinary and cosmetic industries. The 'green strippings', a by-product of fibre processing, has been recorded as an excellent fertilizer and can be used as supplementary food source for cattle (McGruddy, 55). 

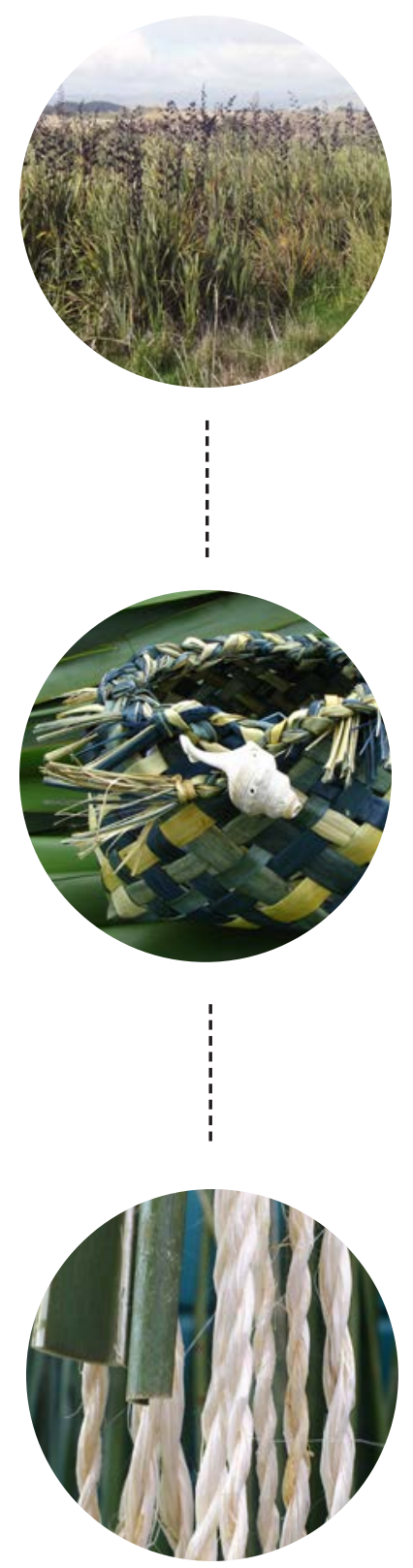

Fig. 75 (top) Harakeke plantation.

Fig. 76 (middle) Woven harakeke baskets. Fig. 77 (bottom) Harakeke fibre.
Within Maori culture, flax is seen as a metaphor for family bonds and human relationships. The plant represents the whanau (family), with the rito (shoot) as the child, protected by the outer leaves representing the awhi rito (parents) and the tupuna (grandparents and ancestors).

Traditionally there are many uses for harakeke. All parts of the plant found use; nectar to sweeten drinks, gum to ease pain and heal wounds, and leaves for weaving baskets and containers. The fibre was woven into a wide range of items, including fishing traps and footwear.

Processing is the most crucial factor in establishing a viable commercial market for harakeke. Presently harakeke exists within a niche market, focused on local and environmental values. However, there is a growing interest in researching processing methods. The result of this research could create a new industry for New Zealand which is environmentally friendly and culturally significant (McGruddy, 10). 


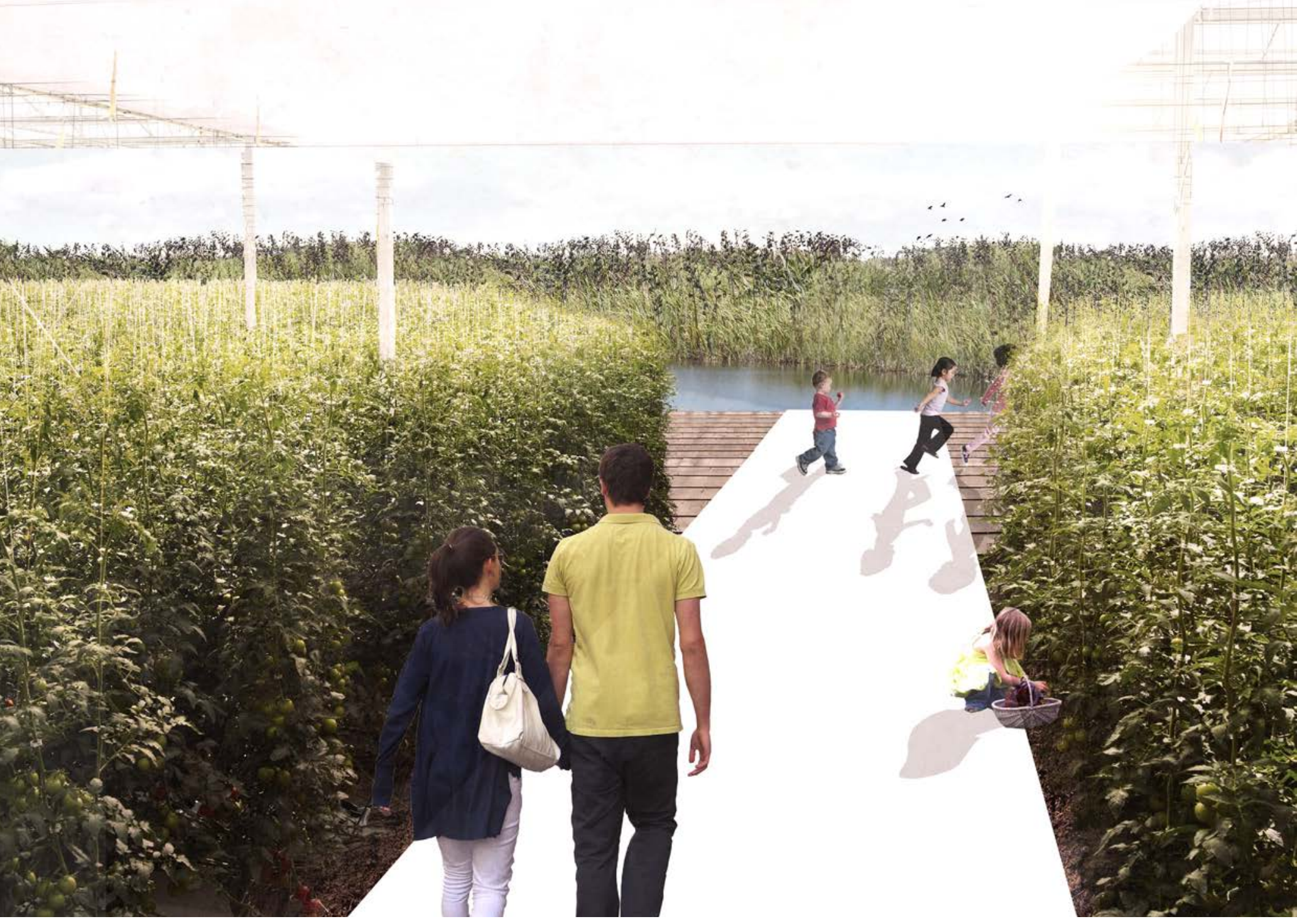

Fig. 78 The greenhouse, located on the edge of the central wetlands, is publicly accessible, opening up on the wetlands and joining with the pathway network. 


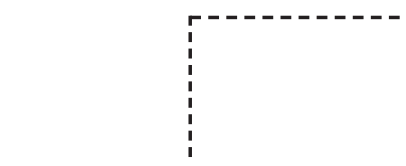

Treatment of Pastoral Run-off

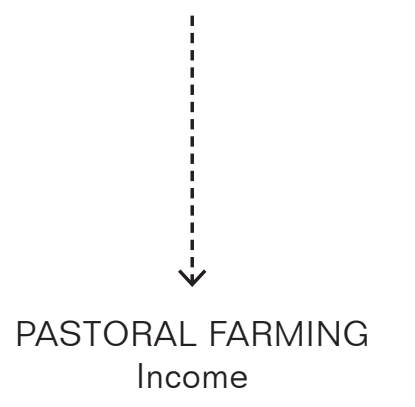

CENTRAL WETLAND SYSTEM

Floodwater Management

Potential for other uses e.g. water harvesting

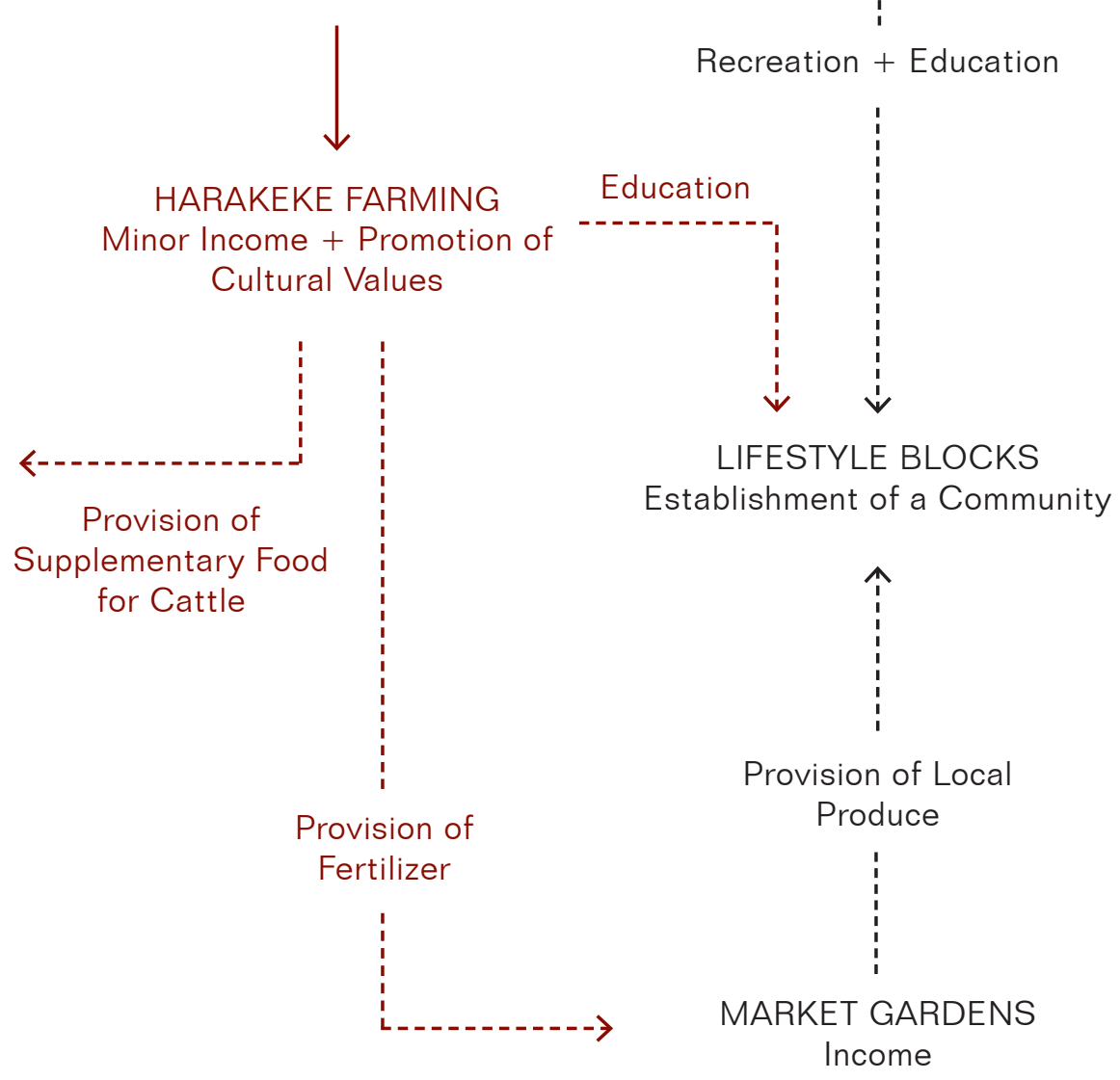

Fig. 79 Diagram of additional benefits to the proposed system with harakeke farming.

The addition of harakeke farming adds another layer of production to the proposed system, with only the addition cost of labour. The floodwater management system is already proposed to optimise the pastoral land and the planting and harvesting of harakeke adds a secondary benefit without disrupting the system. 


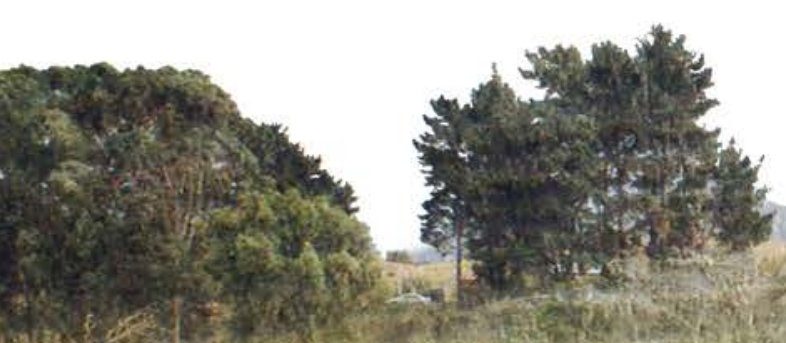

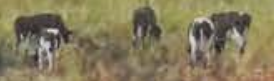

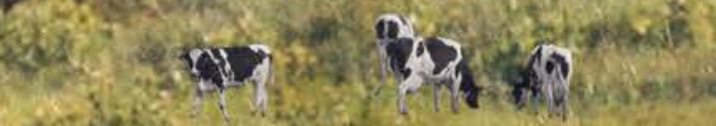

$$
\begin{aligned}
& \text { 4x: } 2: 2
\end{aligned}
$$

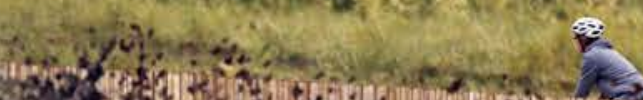

(5) 2 in 43. 35.

\section{5)} ind
A. $x-4,20,40$

(1) 2.

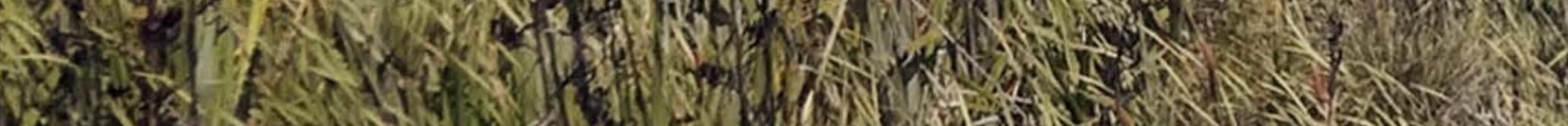
H

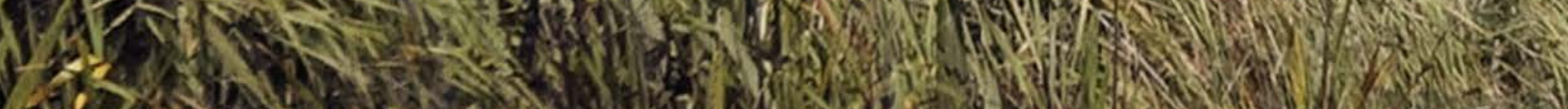
W 3 4) $47+1$

\section{(N) in}

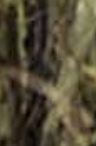




\section{ag a 7}

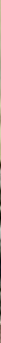

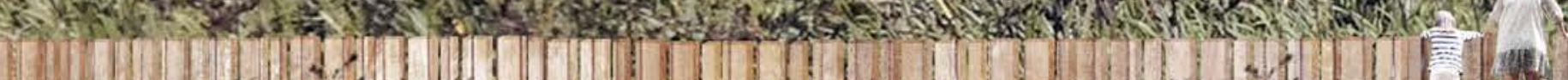

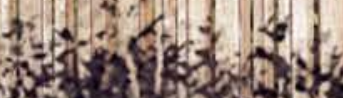

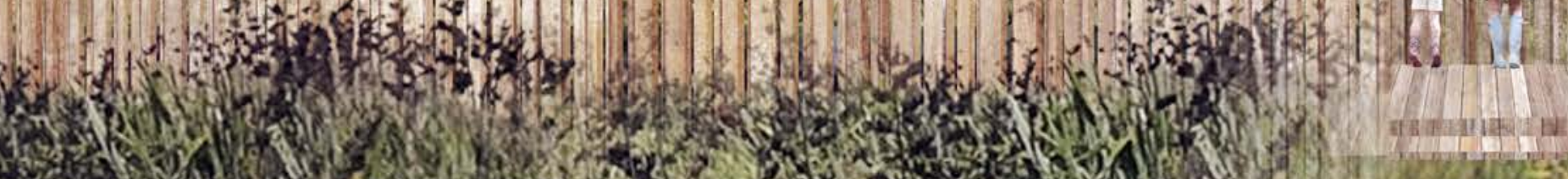

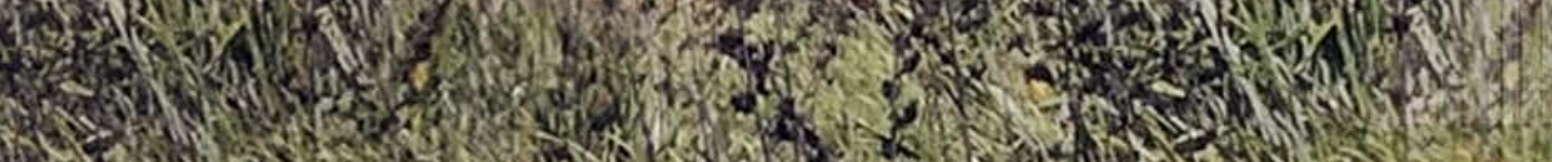

(15)

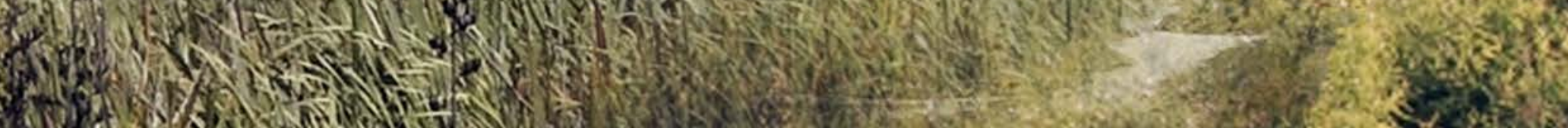

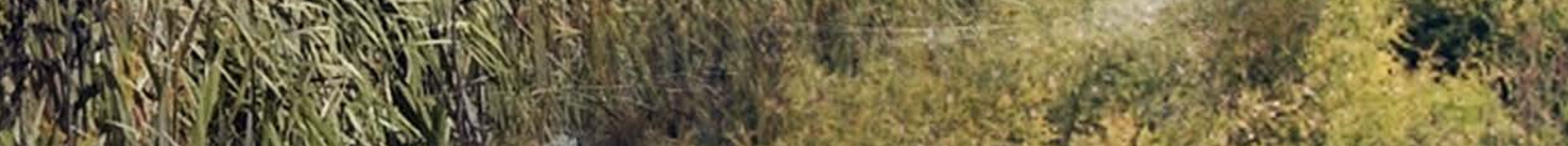
2.1.

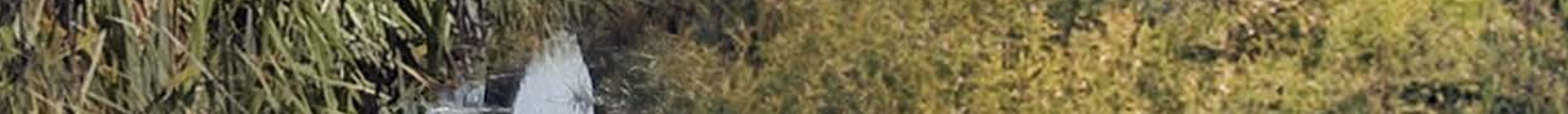
H.

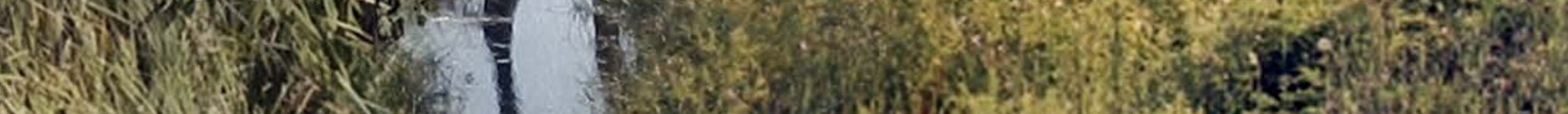
4.2.

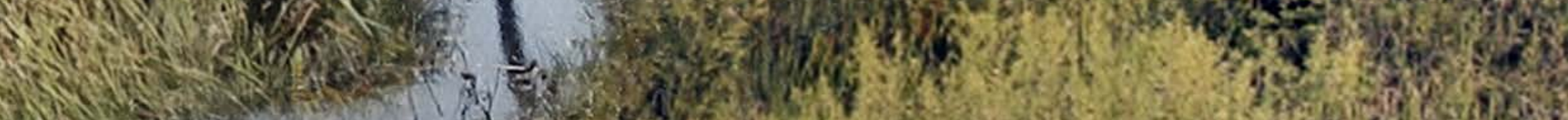

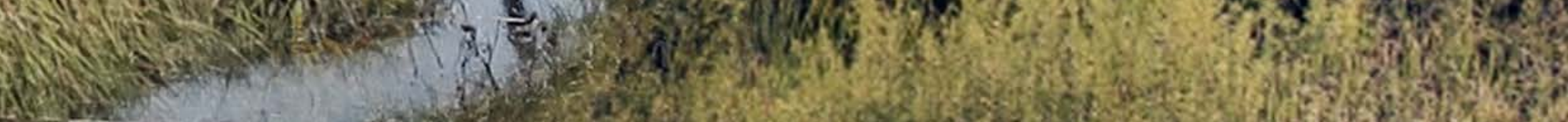

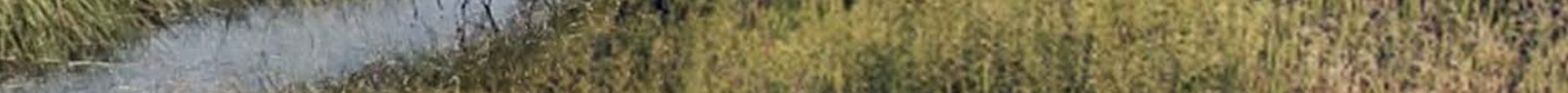

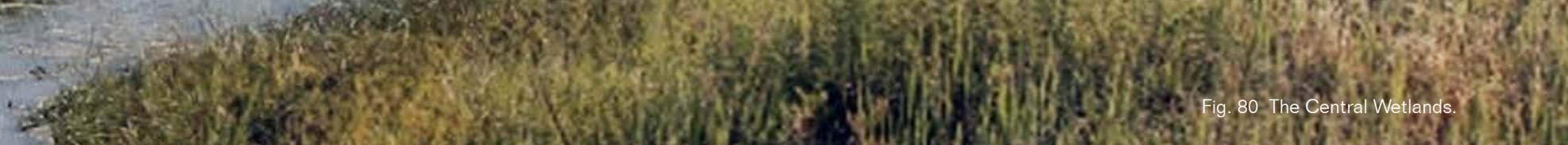
if 


\section{2}

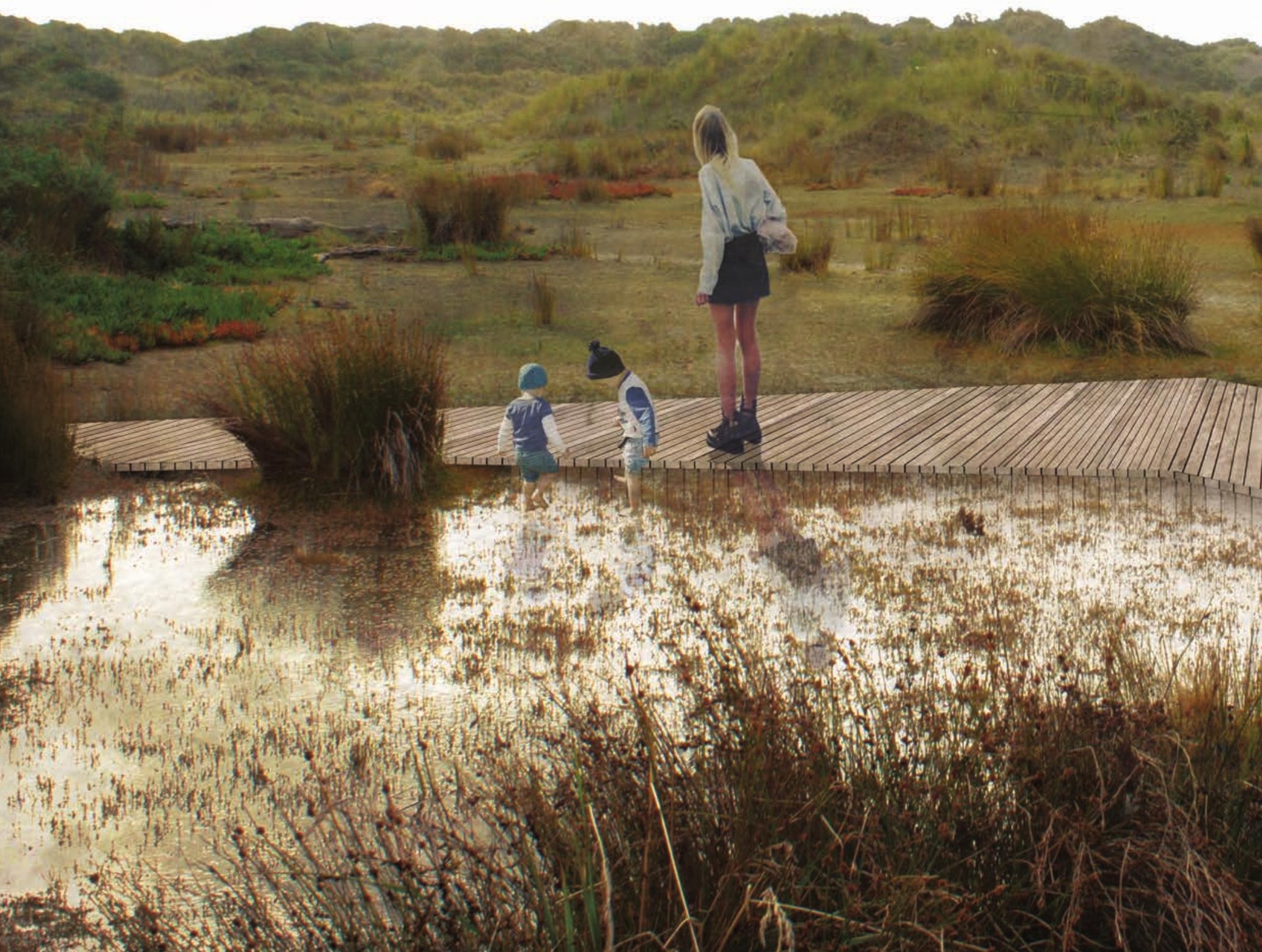




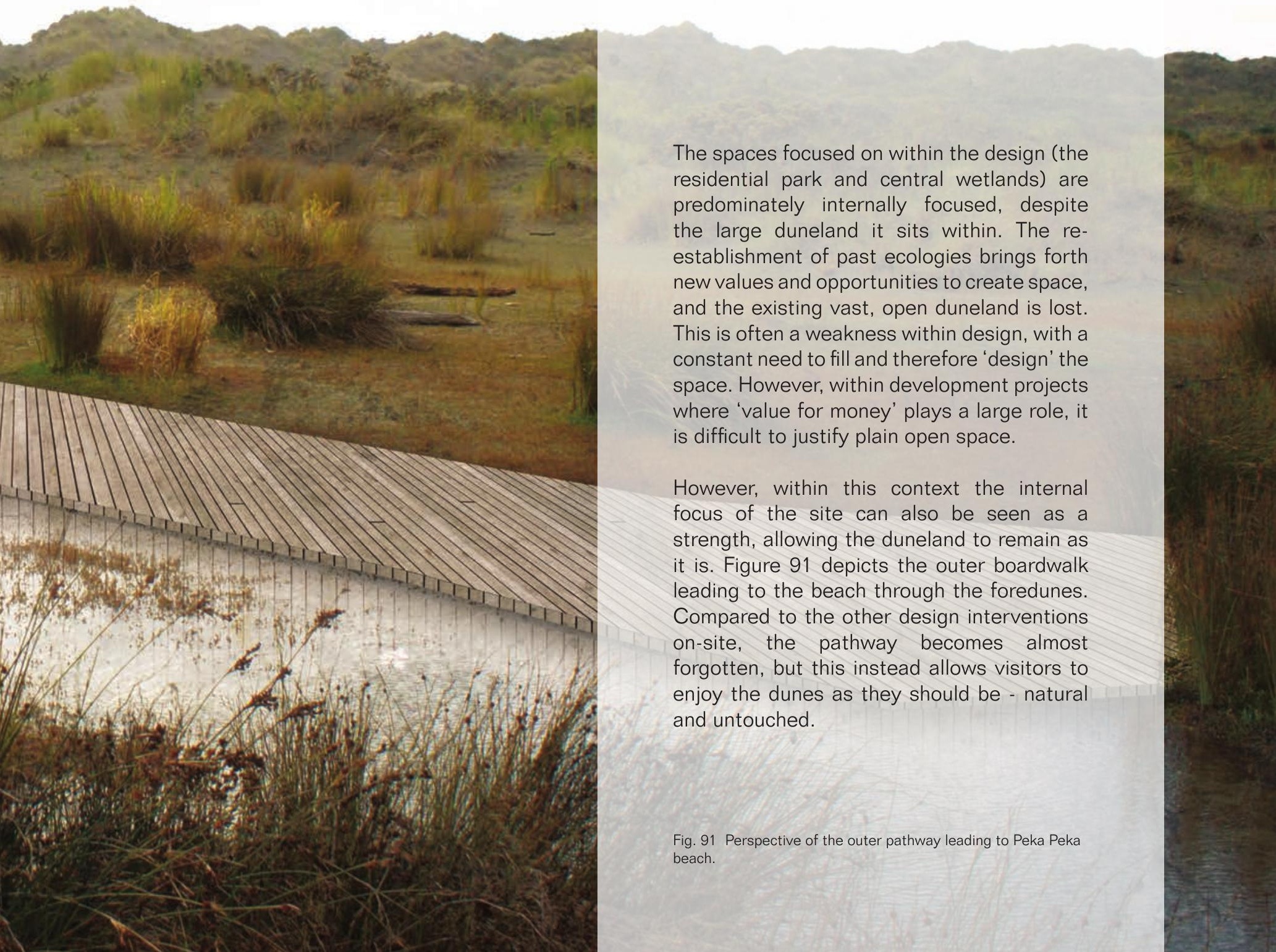


The public right-of-way proposed in the design will create a recreational route from river to river, with smaller loops connecting to the existing roads

Model applied to rural areas along the coast where land is in high demand

OTAKI RIVER

Initial establishment expands the wetland habitat of the Te Hapua Wetlands

Site proposed as a model for the dunelands of Kapiti

The low density of the lifestyle blocks allows the community centres to increase in density

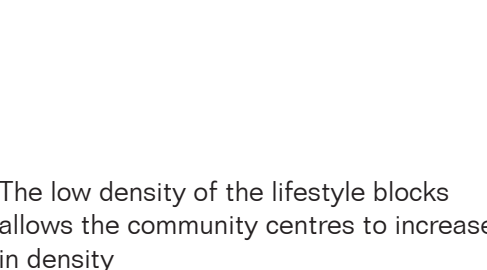




\subsection{AN APPLICATION}

\section{A MODEL FOR KAPITI}

Using the strategies outlined within the design, the site is proposed as a model that can be applied to other rural areas along the strip of flat land between the foredunes and the parabolic dunes. Evidently the community changes along the coast, but key land issues such as the remnant wetlands and the degradation of the foredunes frequent this strip. At its core, this model encourages the diversification of landuse and expresses the importance of green infrastructure to solve the problems caused by the heavy modification of our landscape.

The ownership model and the introduction of the lifestyle blocks therefore becomes means to an end, to satisfy development pressures and fund a large-scale ecological project through private money. While the proposed design can function without its application at a regional scale, the model suggests an opportunity to integrate a working habitat into the everyday rural landscape. Even without the coherence of the strip, applying the model to parts of the duneland will help to strengthen the biodiversity of Kapiti as a whole.

Fig. 92 (left) Diagram of possible application to the Kapiti Coast. 


\title{
A DISCUSSION
}

\author{
Chapter Four
}

"In an environment which has living structure each of us tends, more easily, to become alive

Peter Block - Community: The Structure of Belonging 


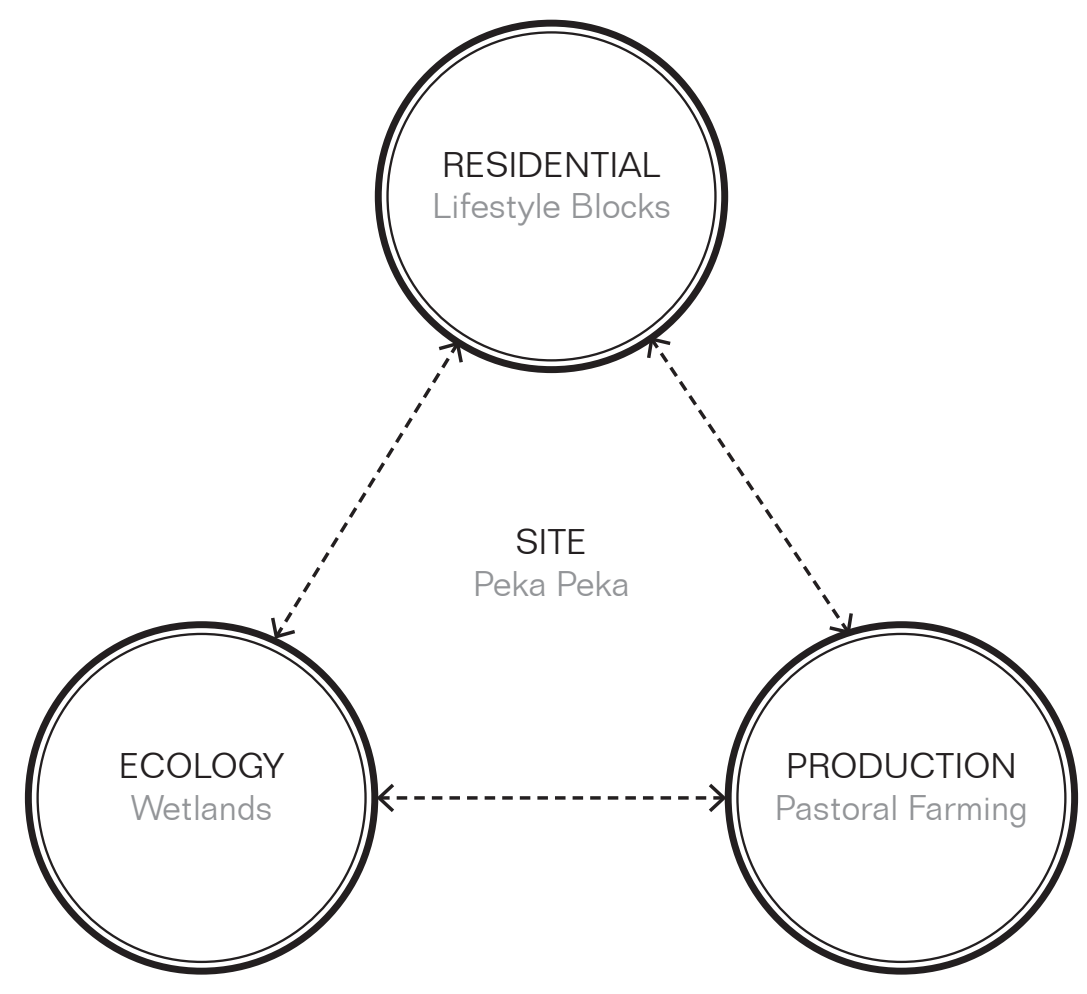

Fig. 93 The three primary land-uses that occur within the design work together to create a holistic system. 


\subsection{INTRODUCTION \\ THE INTEGRATION OF LAND-USE}

This thesis aims to utilise the integration of land-use types to suggest new strategies for residential development within the rural environment. The role of landscape architecture seeks to fulfil the potential of this integration by examining the spatial qualities and the interrelationships of people, economy and the land. The three primary land-use types, ecology, production and residential, each provide a set of specific demands that are reoccurring throughout Kapiti and New Zealand's rural landscape. However, the integration of land-use allows these separate problems to be solved together, creating a holistic system that is more diverse and therefore more resilient.

Through the process of design development a number of principles have been reached that could be used to aid the design process within future residential development in rural environments. This chapter will discuss these outcomes in relation to three key topics; rural subdivision, scale and the creation of a system. It will also review the case studies and design exploration which led to these outcomes. 


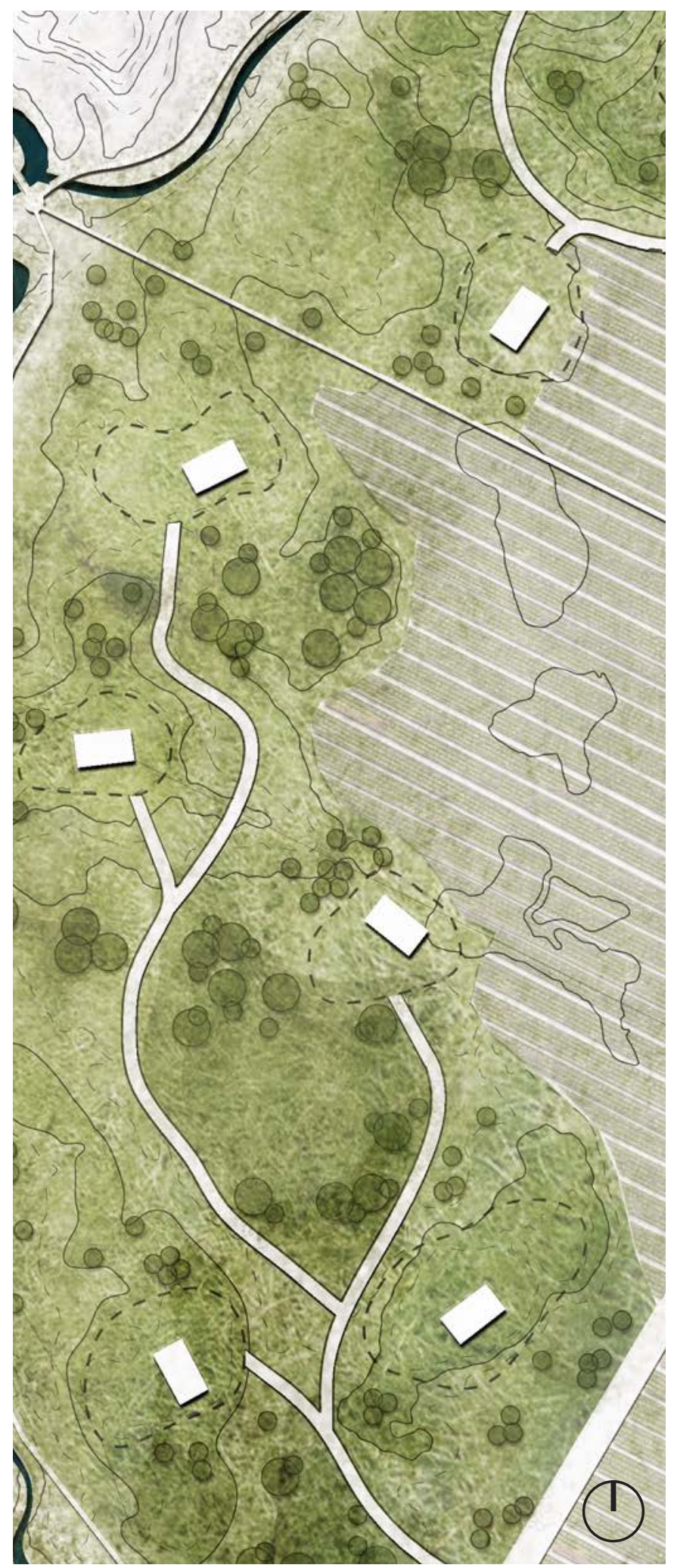




\subsection{LIFESTYLE}

\section{AN ALTERNATIVE APPROACH TO SUBDIVISION}

Kapiti Coast's commuter culture provides a key opportunity for the diversification and integration of land-use. Production has always been a part of lifestyle blocks, with the large plots of land serving as personal, private farms, but the incorporation and acknowledgement of an ecological system is a more recent, if sometimes tokenistic, addition. However, its low maintenance nature makes it highly compatible with the commuter lifestyle. The cost of ecology, therefore, becomes the largest problem to overcome.

Reconnecting residents to nature within their everyday lifestyle is an important part of changing the way we invest in ecology. The design starts to acknowledge this through its spatial arrangement, creating a relationship to the natural features of the site through the placement of housing. Working with the topography, the dunes, the wetlands and the regenerative bush become a part of the resident's backyard with shared responsibility and ownership. The care of the landscape directly correlates to the value of the property, forcing the residents to take charge of their ecological systems.

The design also installs a series of public pathways throughout the site. This ensures the development does not become similar to a gated community and creates a connection to the wider community. These pathways are designated away from the residential area to ensure privacy, but run through the site none the less. Better accessibility to our landscape will encourage interaction with our ecological systems and help to demonstrate the possibilities of rural subdivision.

Fig. 94 (Opposite) Detail Plan of Residential Park 1:2000. 


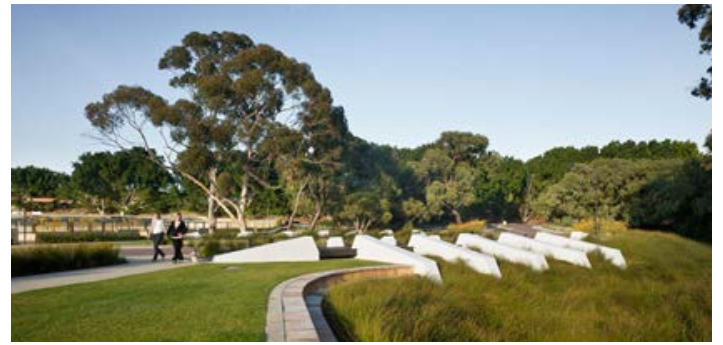

Fig. 95 Lakeway Redevelopment.

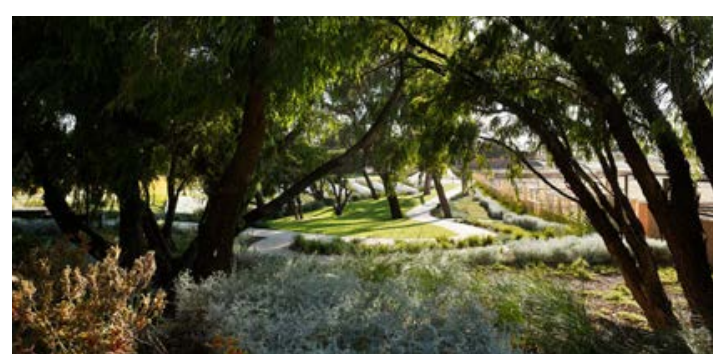

Fig. 96 Lakeway Redevelopment.

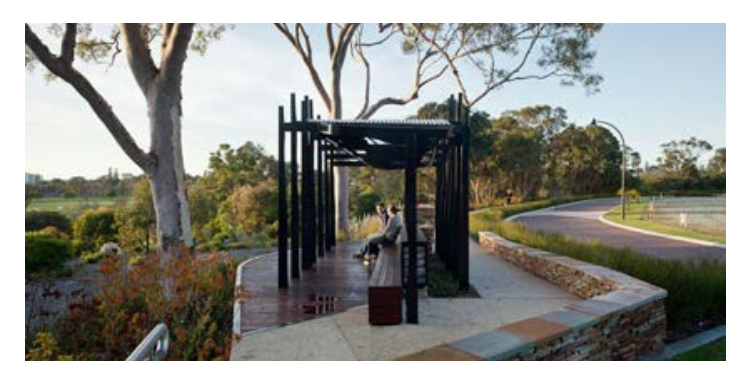

Fig. 97 Lakeway Redevelopment.

\section{CASE STUDY \\ LAKEWAY REDEVELOPMENT, PERTH}

Designed by Hassell, Lakeway is a residential development in the coastal suburb of Swanbourne. It is redeveloped from an old drive-in theatre and sits upon a wooded dunal escarpment. The design sets aside a third of the site for bush regeneration and creates a parkland which serves the adjoining school and residential area.

Although within a different context, the development is a key example of combining residential with ecology. The designer's intention works to establish a strong sense of place through the values symbolised by place. This is done through expressing the community's desire to preserve and enhance the existing remnant bushland.

Like the proposed design, the location is a key element in the attractiveness of the development, but the connection with the historic landscape is undeniably a catalyst in engaging the wider community. This is enforced by the design of the space, using details to connect visitors to the natural environment (fig. 98, 99). 
Vegetation creates a buffer between pedestrians and the road and treats stormwater run-off

The width of the pathway allows visitors to walk together while still creating a sense of intimacy

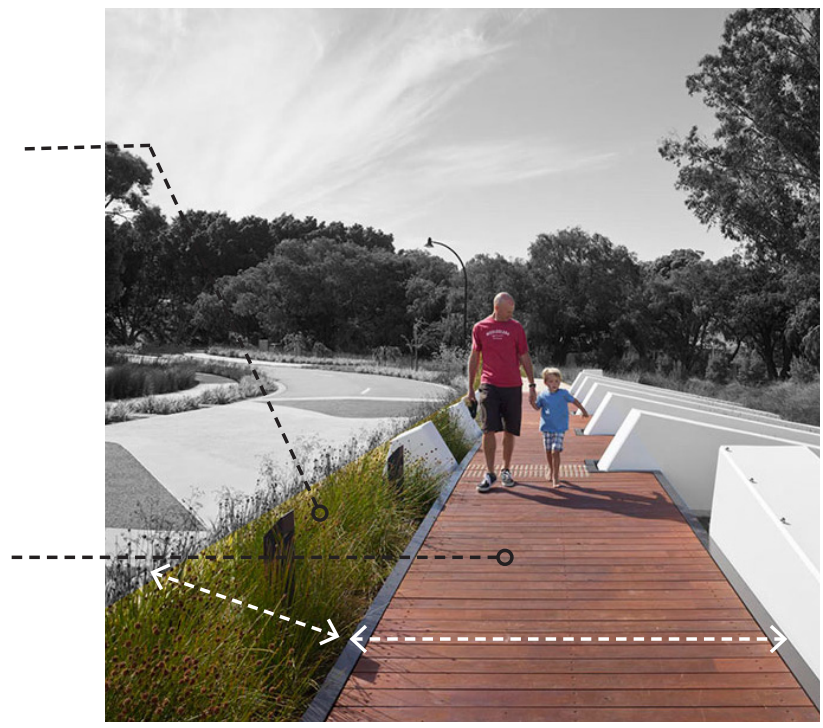

Fig. 98 Lakeway Redevelopment

The gentle slope of the plinth allows visitors to get closer to the wetland

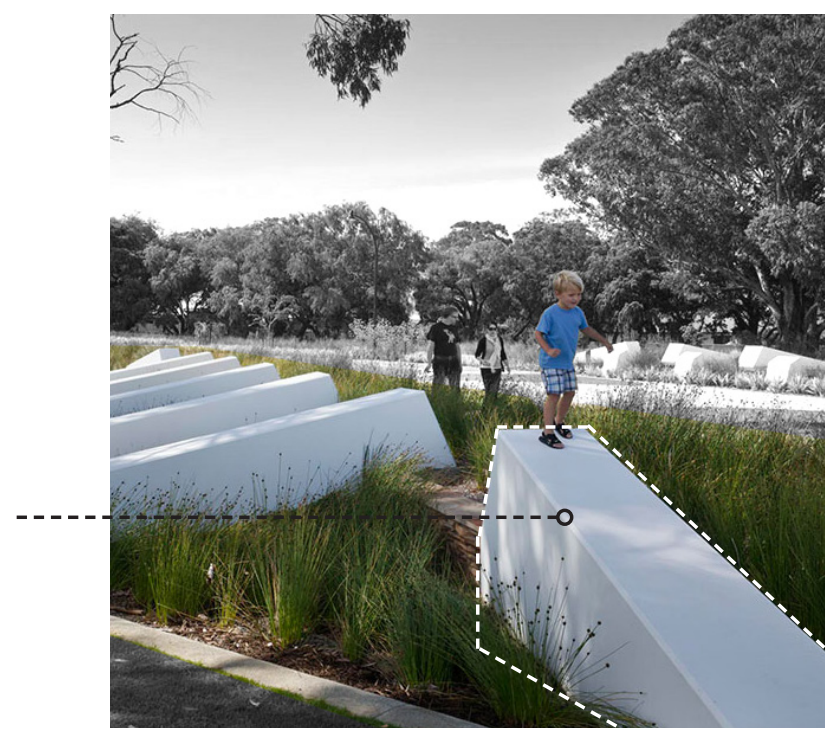

Fig. 99 Lakeway Redevelopment. 

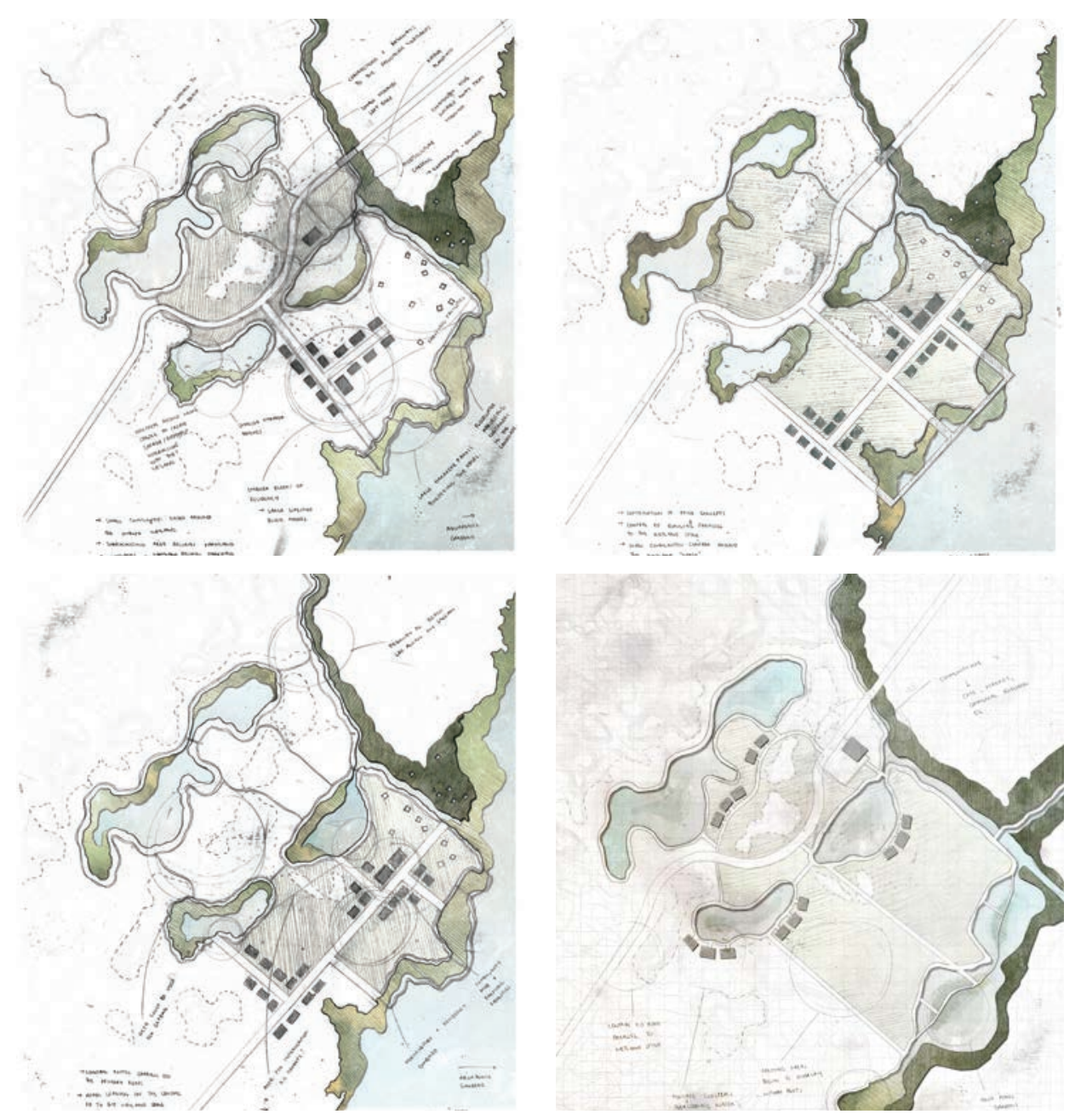

Fig. 100 Some early iterations exploring the arrangement of the site. These iterations initially proposed a seeding plan with the area around the lakes as a hub. 


\subsection{LIFESTYLE \\ CAN DESIGN BUILD COMMUNITIES?}

Within design it is difficult to measure how much of an impact a space has on building a community. A sense of connection or belonging often depends on much more than the space and it could be argued that the type of people that inhabit the space is the most important factor. However, it cannot be disputed that space is a contributing factor. Peter Block, author of Community: The Structure of Belonging, writes that "we need large community spaces that have those qualities of great communal intimacy" (151). This means that even if designers cannot control the type of interaction that happens within the community, it is still imperative to provide spaces that promote communal activities.

The initial design tests were focused around the idea of a street (refer to figure 100), a mutual, shared area where people could meet. However, within a rural environment the street holds less power. With less people and fewer destinations in walking distance, it is less likely these interactions would occur. This prompted a shift in the spatial arrangement, to focus towards natural features and create spaces in which people could gather in. It became less about the private properties and more about the communal spaces, the spaces designers should be focused on. 

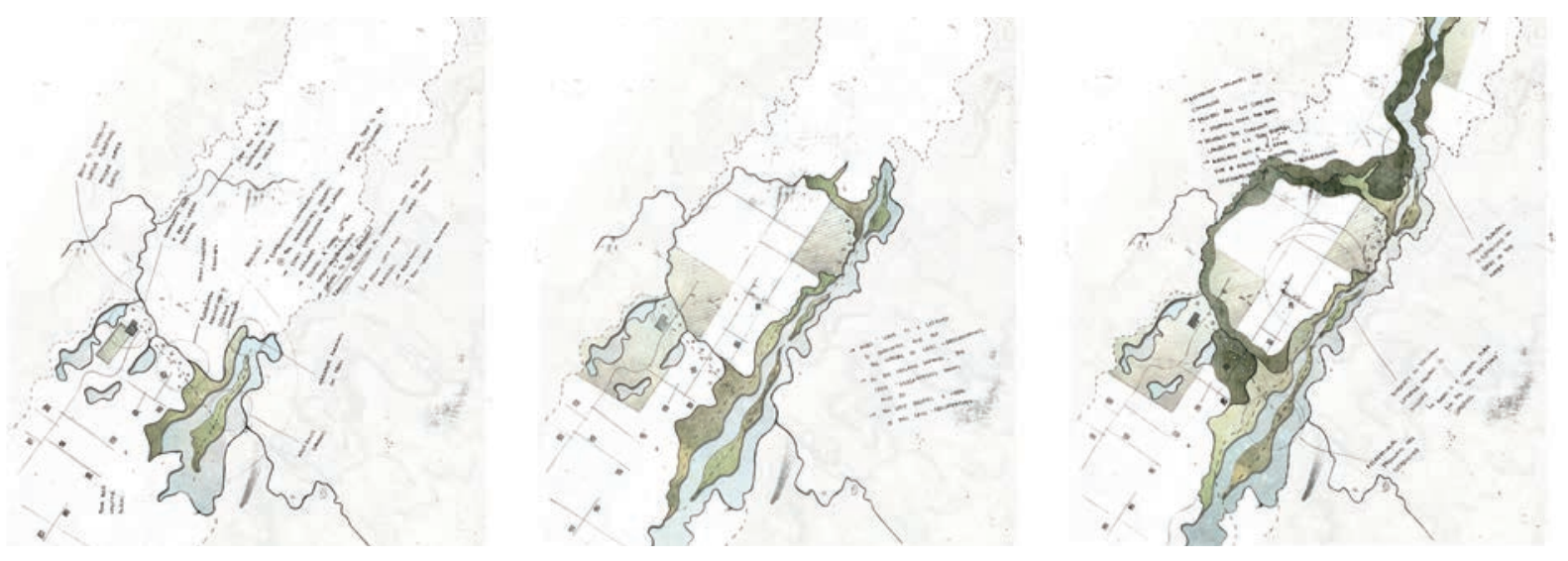

Fig. 101 Conceptual diagram of a proposed seeding scheme. 


\subsection{LIFESTYLE \\ SEED, SCHEME OR BOTH?}

The implementation of the project as a seed or a scheme is a key consideration in the success of the project as a development. A seeding project works to pinpoint the key problem and use it as a catalyst to further inspire other projects, while a scheme usually works to resolve a number of problems at once. The initial design iterations explored a seeding approach, adapting the site to become a part of a farming hub to draw interest in the area and diversify the farming practices. However, while a more traditional approach, the impact and scale of implementing a scheme was a key factor in creating funding for the ecological development. Therefore it is important to look at design from both perspectives, considering the immediate and future impacts of implementation. 


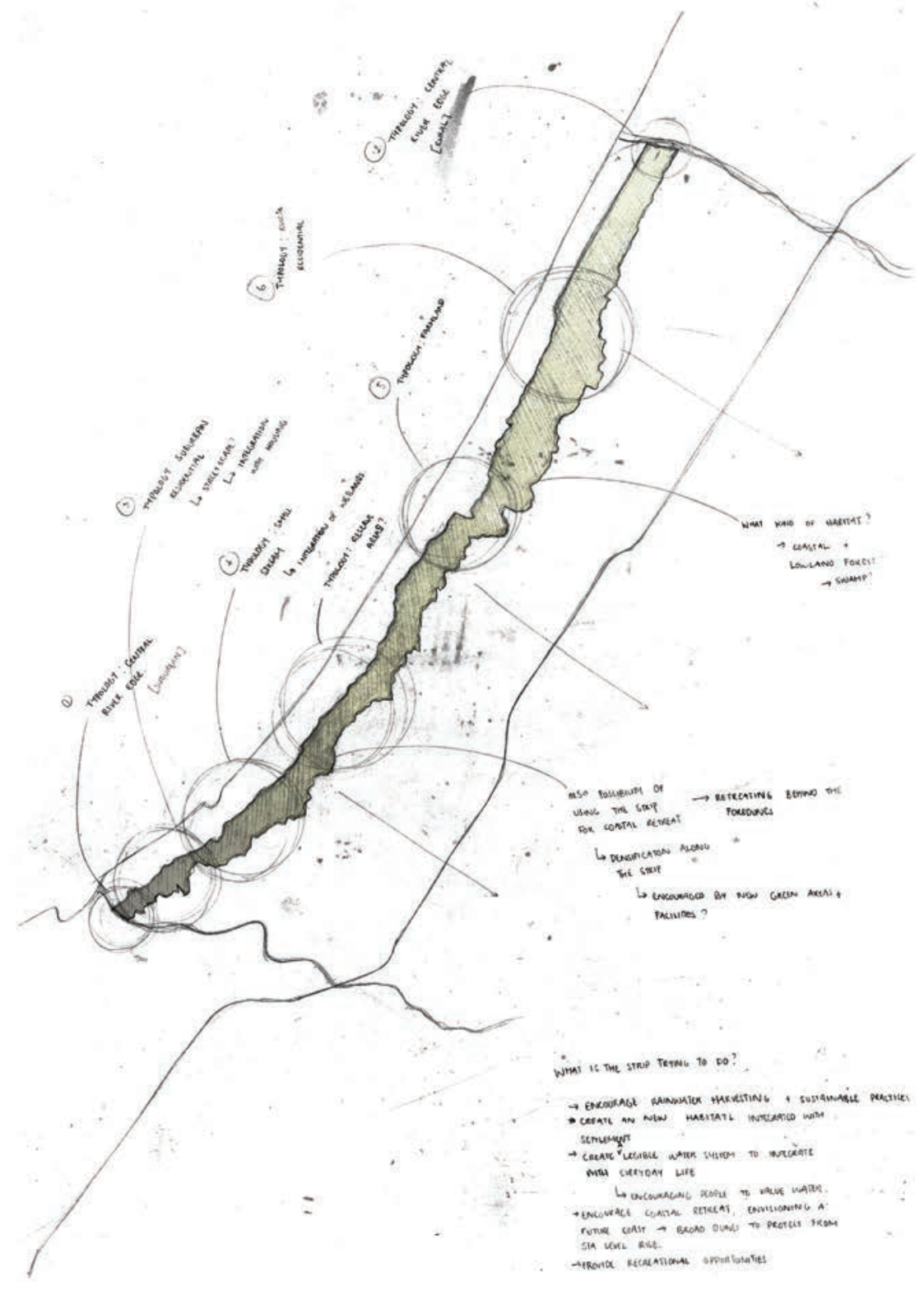

Fig. 102 Sketch of the initial hunch depicted an ecological corridor that ran from the two main rivers within the lee of the dunes. 


\subsection{SCALE \\ SUBDIVIDING AT A RANGE OF SCALES}

An important aspect of integrating multiple land-uses is the consideration of the design at a range of scales. Subdivision too often focuses on the scale of the masterplan, losing the potential to connect meaningfully to both the wider context and its residents. Lifestyle blocks rely heavily on location as a selling point, but miss the opportunity to have an impact on our already degraded landscape. The Tasman Lakes development is an example of this, using the beauty of the lakes to attract residents with little restoration or consideration as to how these lakes could benefit the residents and the community in a way that isn't simply visual.

A connection to the wider landscape was a key driver for the design. A connection to the dunes, the ranges and the remnants of the swamp were always on the forefront of the design process and these in turn, drove many of the design considerations at the smaller scale. An example of this was the design of the wetland boardwalk. Details such as the slight tilt of the balustrade and the small gaps to allow the harakeke to grow through, all relate to getting visitors closer to nature. People are the most powerful advocates for the land and these small design considerations help to build a more intimate relationship, therefore fostering a greater sense of ownership and responsibility. 


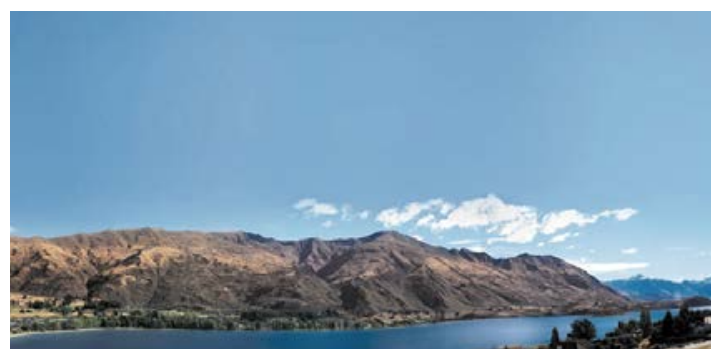

Fig. 103 Promotional Image of Hillend Station.

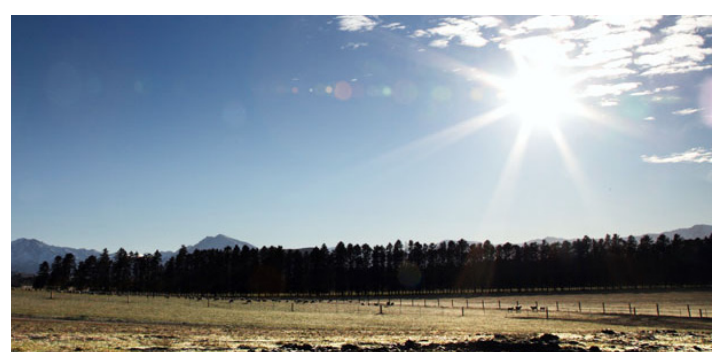

Fig. 104 Promotional Image of Hillend Station.

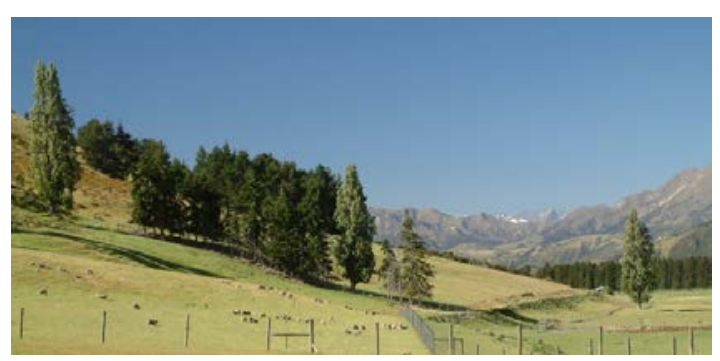

Fig. 105 Promotional Image of Hillend Station.

\section{CASE STUDY \\ HILLEND STATION, WANAKA}

Hillend Station is a new residential development five minutes out of Wanaka, a small town in the South Island of New Zealand. It boasts an outstanding landscape, overlooking Lake Wanaka, with the whole station acting as the resident's backyard. The station is a fully functional farm with 6000 stock units of sheep, cattle and deer. Residents are welcome to visit the farm workshops and see the farmers at work.

Similar to Parkhill Farm, the communal areas are managed by a Resident's Association and funded by a communal levy. However, unlike Parkhill, the annual work plans of the farming operation are also reviewed by the Resident's Association to ensure best work practices, giving residents some input into the productive side of their home. Hillend also imposes a series of design guidelines to ensure preservation of the site's character.

From a design perspective, Hillend is a good example of considering the development from a range of scales. The landscape is the site's greatest asset and this has been acknowledged through a range of design decisions that operate right down to the resident's backyard. 


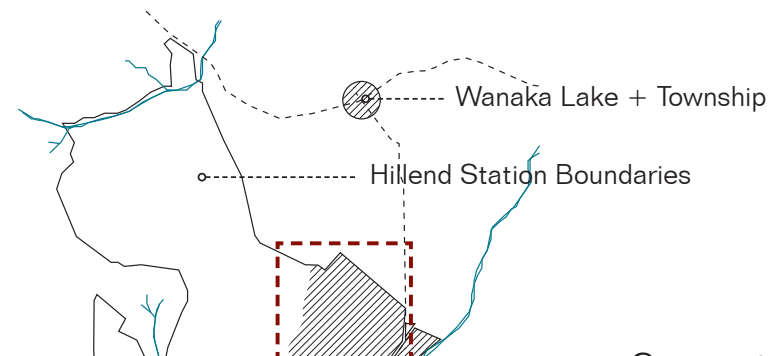

Connection to Wanaka Township and

Regional Scale

Lake + Protection of the Ranges

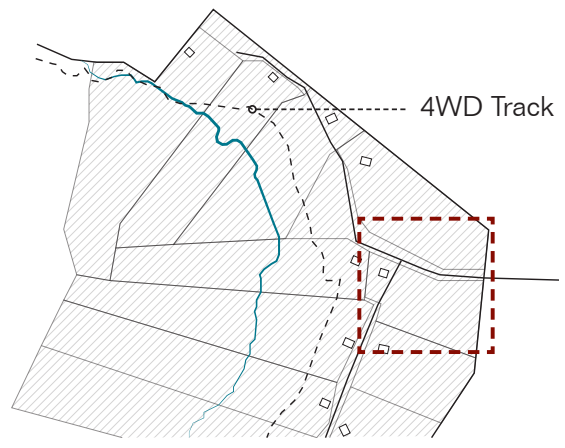

\section{Site Scale}

Connection and Preservation of

Waterways + Communal Access

Routes through Private Property

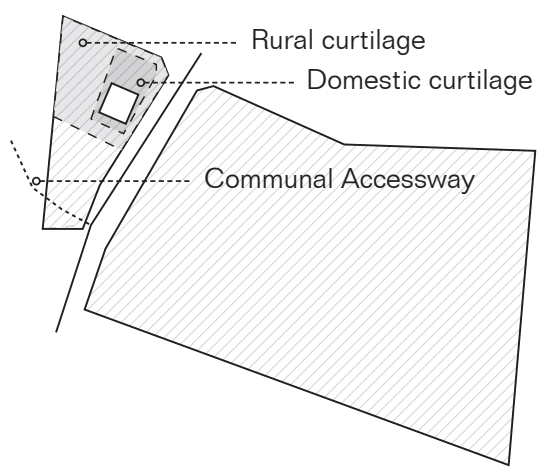

Residential Scale

Control of Buildable Area on Property

+ Environmental Guidelines

Fig. 106 Diagram illustrating design decisions at a three scales. 

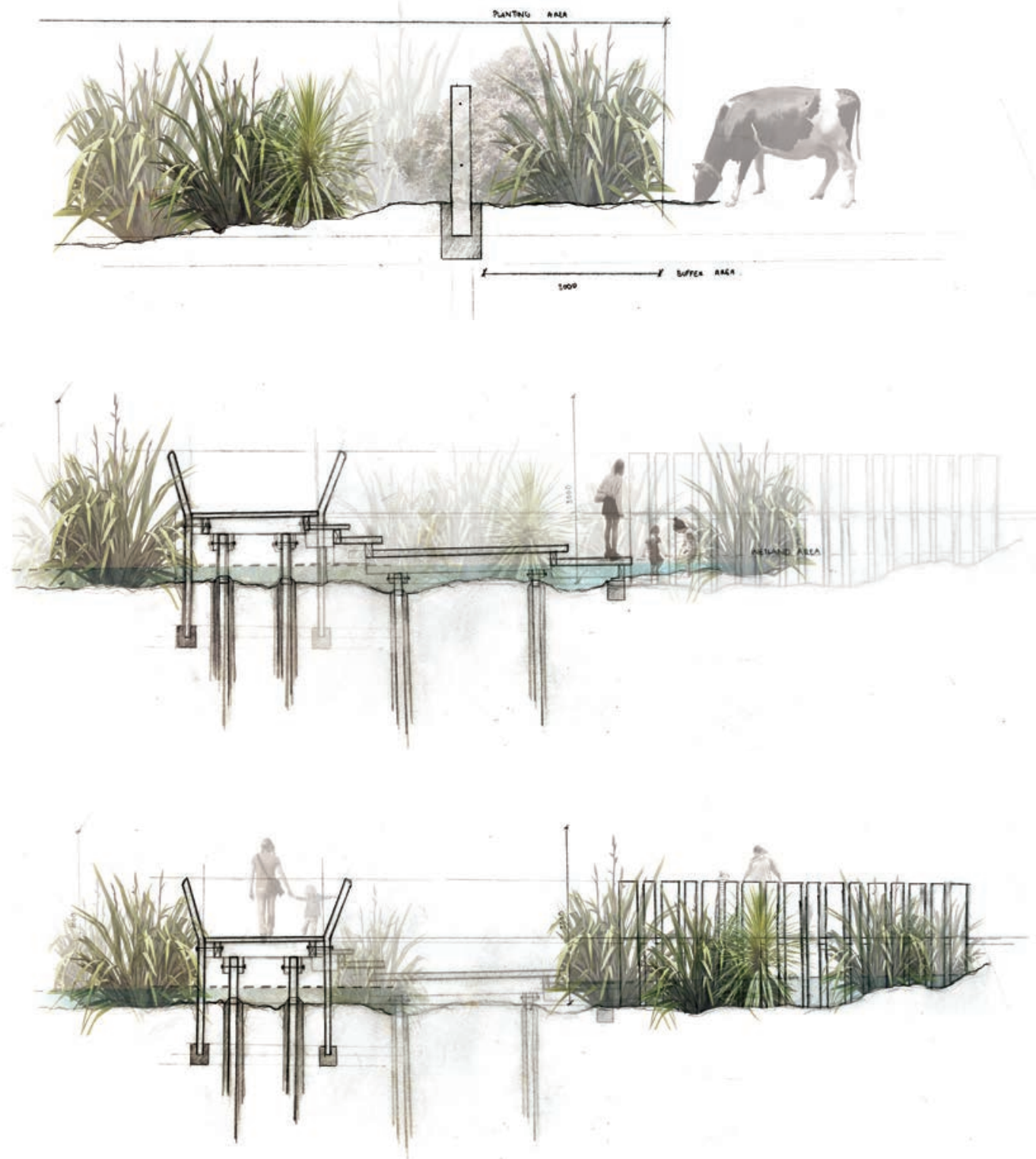

Fig. 107 Exploration of small scale details work to ensure a level of synergy between the primary land-uses. 


\subsection{SCALE \\ DESIGNING THROUGH SECTIONS}

Sections were a key tool in testing the design at a range of scales. The integration of land-use resulted in a number of edge types where two or more land-uses would meet. These edges are a key factor in the spatial arrangement of the design and were explored even in the smallest of details. As land-use and landscape planning is too often done through plans and sections provide an opportunity to connect with the human scale.

Design tests considered larger details such as how the housing might relate to the wetlands (fig. 109) as well as small details such as how the fence might be hidden within the harakeke to create a seamless transition while protecting the waterway (fig. 107). 


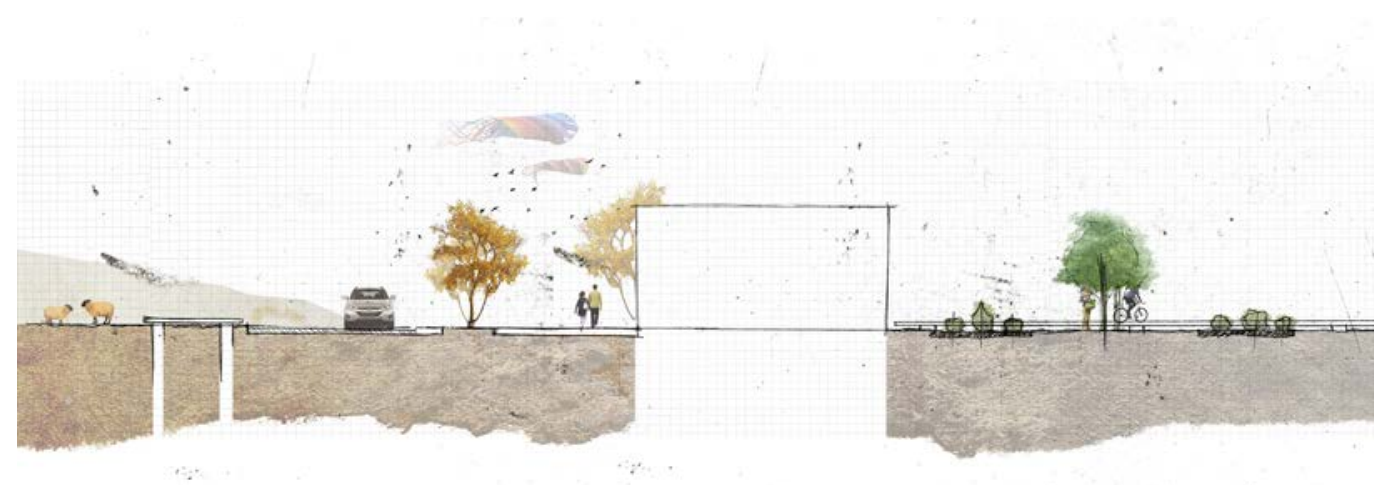

Fig. 108 Section explored a community centre with community gardens within the residential estate.

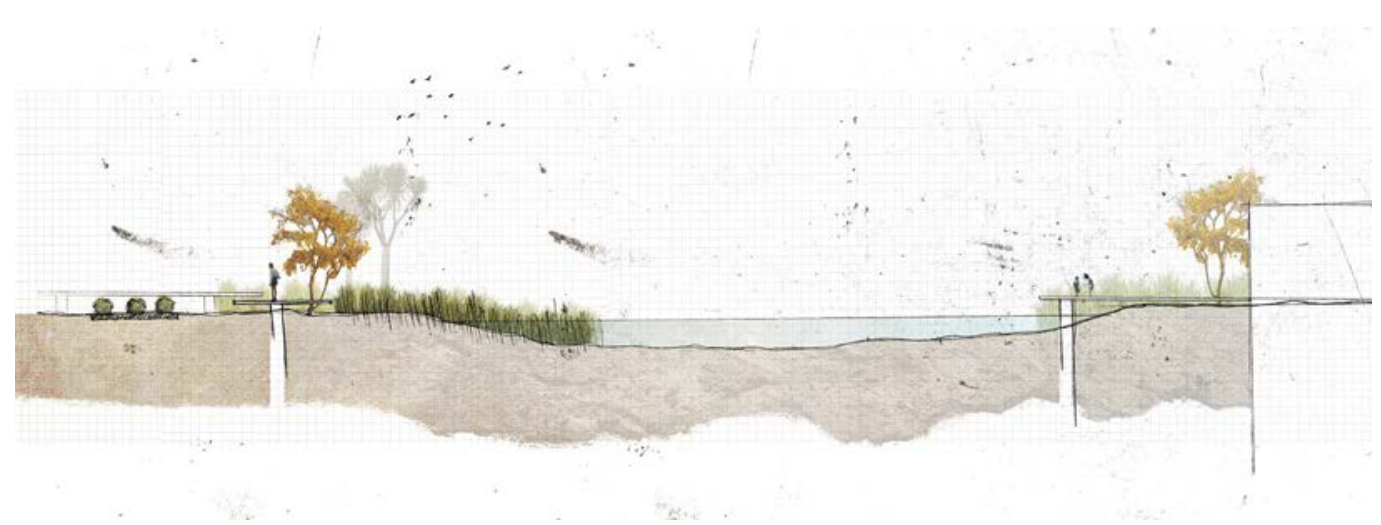

Fig. 109 Exploration of the wetland edge and housing.

Sections shifted the focus towards the ground conditions and allowed testing for a number of alternative arrangements in relation to land-use. The design primarily uses soil and water to create a framework in which land-use can be placed, however, this is meaningless without knowing 


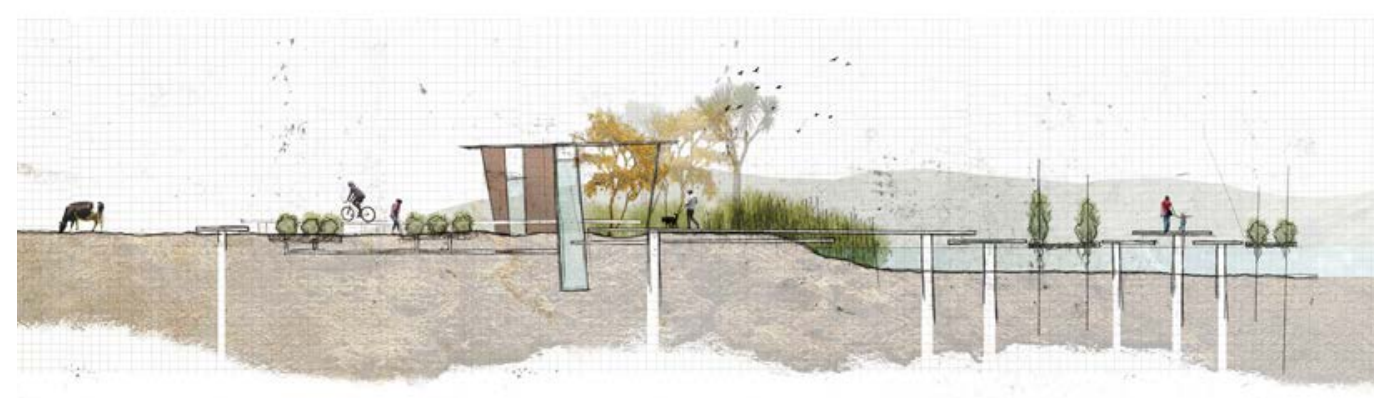

Fig. 110 Section explored uses for wetlands other than harakeke farming.

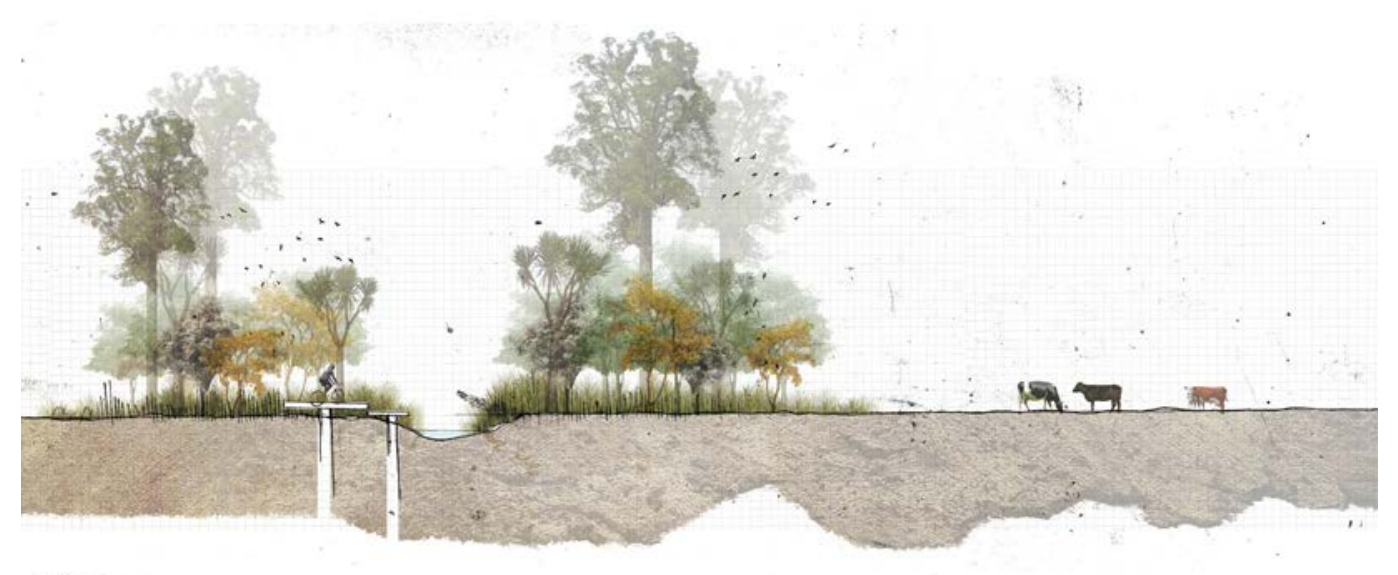

Fig. 111 Exploration of vegetation buffers to separate pathways without fences.

the implications on the ground. A number of alternative land-uses were considered, including aquaponics (fig. 110) and a community garden (fig. 108), but these were determined to be not viable within the limitations of the site and context. 



\subsection{SYSTEM}

\section{CREATING A WORKING LANDSCAPE}

One of the key requirements for successful integration is to create a working landscape. Too often rural land gets locked up in private residential properties which focus too much on visuals, resulting in little or no ecological or productive value. The design examines rural subdivision as an opportunity to access large amounts of connected land and use this potential to create a system within the site. The proposed ownership system, adapted from recent precedents in New Zealand, plays a large part in allowing this to happen. This particular system acknowledges the commuter culture within the Kapiti Coast, which is more prevalent in beach settlements such as Peka Peka, and uses their desire for large, but low maintenance properties to integrate ecosystem services into their backyard. Under private management, the residents can enjoy the benefits of the landscape without having to care for it personally.

The design also looks at creating a working landscape in the simplest of terms, by determining what within the landscape was not working. Using natural processes to optimise the drainage system allows the adjacent livestock farm to increase its stocking rate while improving the state of the land. The new wetlands allow for a larger flooding capacity and a new water treatment system, as well as providing a new habitat for wetland species and the possibility of future fibre production with the establishment of a harakeke patch. This, however, means there is a smaller amount of land that can be used for production, which is the usual argument against installing ecosystem services. The proposed ownership and management system helps to combat this, by taking away the responsibility of managing the wetlands, yet allowing the farmers to benefit from these ecosystem services.

A realistic balance between ecology and production therefore becomes possible by looking at the working landscape. Ecology should be an aid to production within a working landscape, not a substitute. 


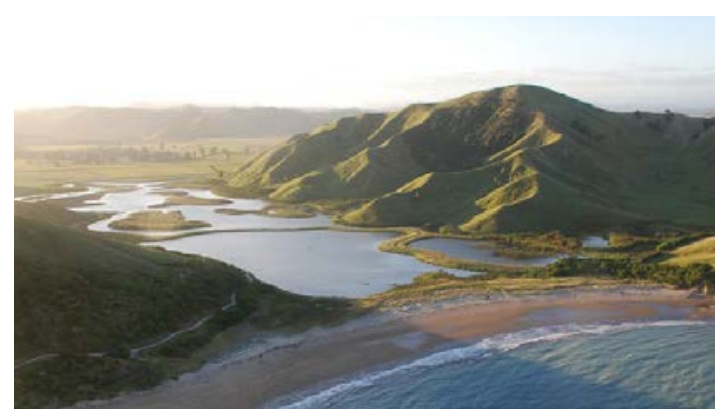

Fig. 113 Orongo freshwater and saltwater wetlands.

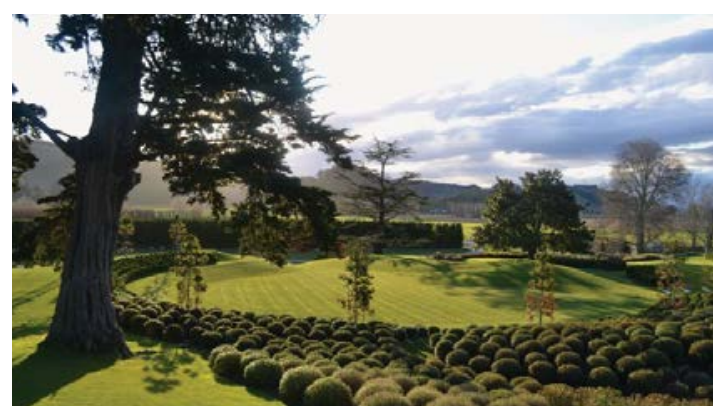

Fig. 114 Outer gardens of the Orongo Station.

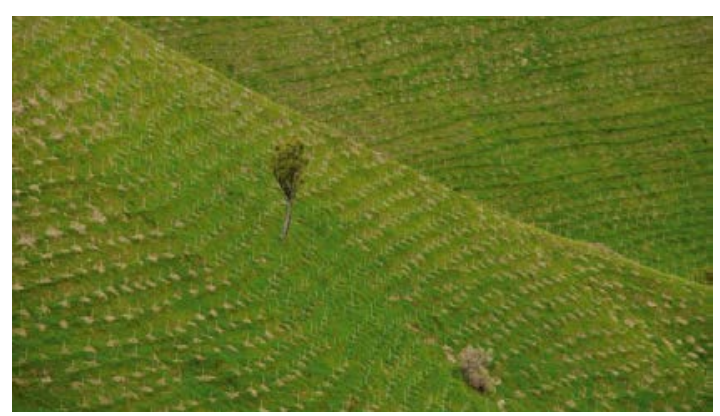

Fig. 115 Beginning of the reforestation efforts.

\section{CASE STUDY}

\section{ORONGO STATION, NEW ZEALAND}

Orongo Station is an ambitious, decade long project that has become a prime example of the successful integration of ecology and production. Designed by Nelson Bryd Woltz, the project focused on the restoration of a 3000 acre sheep farm to undo 100 years of ecological damage. Over 500,000 trees have been planted for reforestation and over 75 acres of freshwater and saltwater wetlands have been restored and constructed, all while increasing the economic viability of the farming operations.

The main feature of the site is the bold, curving wetland, designed with scientific data to create a fully functioning wetland that is clearly constructed rather than naturally formed. This serves as a way to expand the range and diversity of the wildlife habitat.

Grazing sheep and livestock was tough prior to the project, due to the brutal salt spray and erosion on the exposed slopes, and the reforestation has helped to stabilise and protect the landscape. The farming has further expanded to include horticulture, namely the citrus fields on the flats, working to diversify the land further.

Although not a residential development, Orongo Station is the definition of a working landscape and was a key influence in how these types of systems could be achieved. 


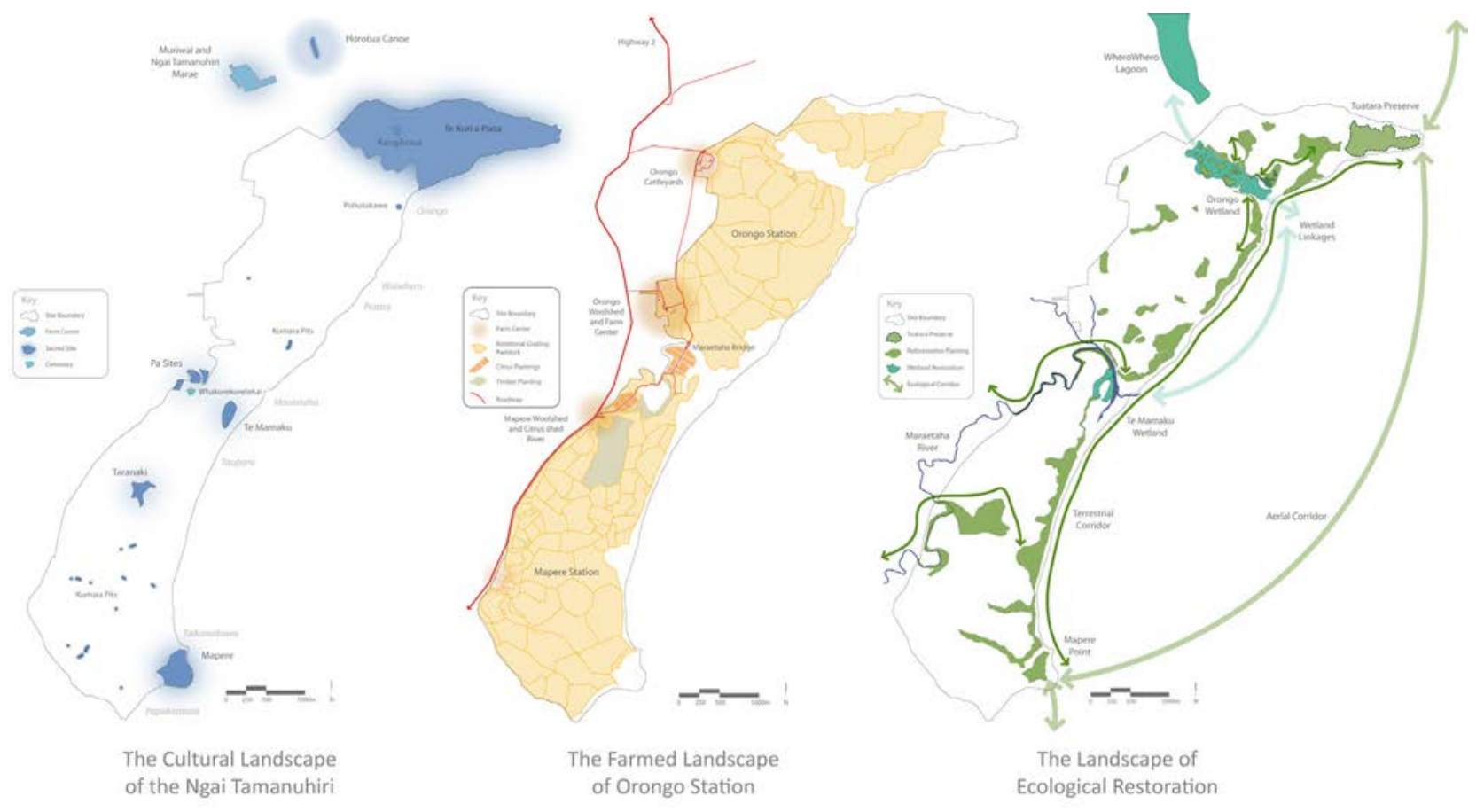

Fig. 116 The masterplan considers the cultural, productive and ecological aspects of the project simultaneously. 


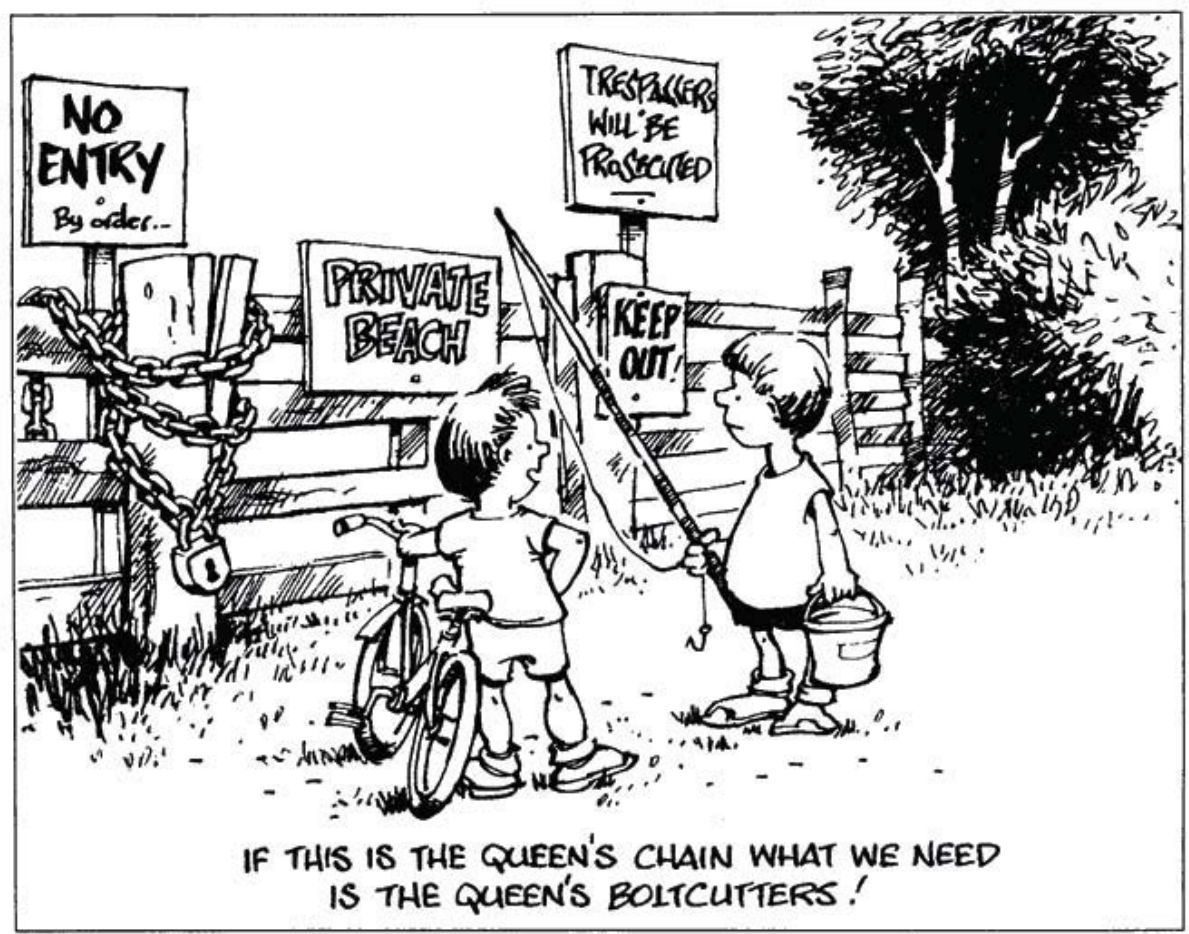

Fig. 117 Garrick Termain's cartoon in 1990 points out that $30 \%$ of the nation's coast is not publicly accessible, despite the notion of the Queen's Chain. 


\subsection{SYSTEM \\ THE QUEEN'S CHAIN}

The Queen's Chain is a term used to describe the strips of land next to the foreshore, rivers and lakes that are publicly owned. These spaces were initially set aside for ease of access, but are increasingly being used for conservation as well. The design proposes a version of this, designating pathways as public right-of-way and allowing a semblance of public access to an otherwise private site. By proposing this, it argues that wetlands are equally as important as rivers and lakes and should have similar levels of accessibility and preservation. It is a relatively controlled form of public access, restricted to pathways and confined areas, but it begins to suggest the possibilities of an open landscape. 


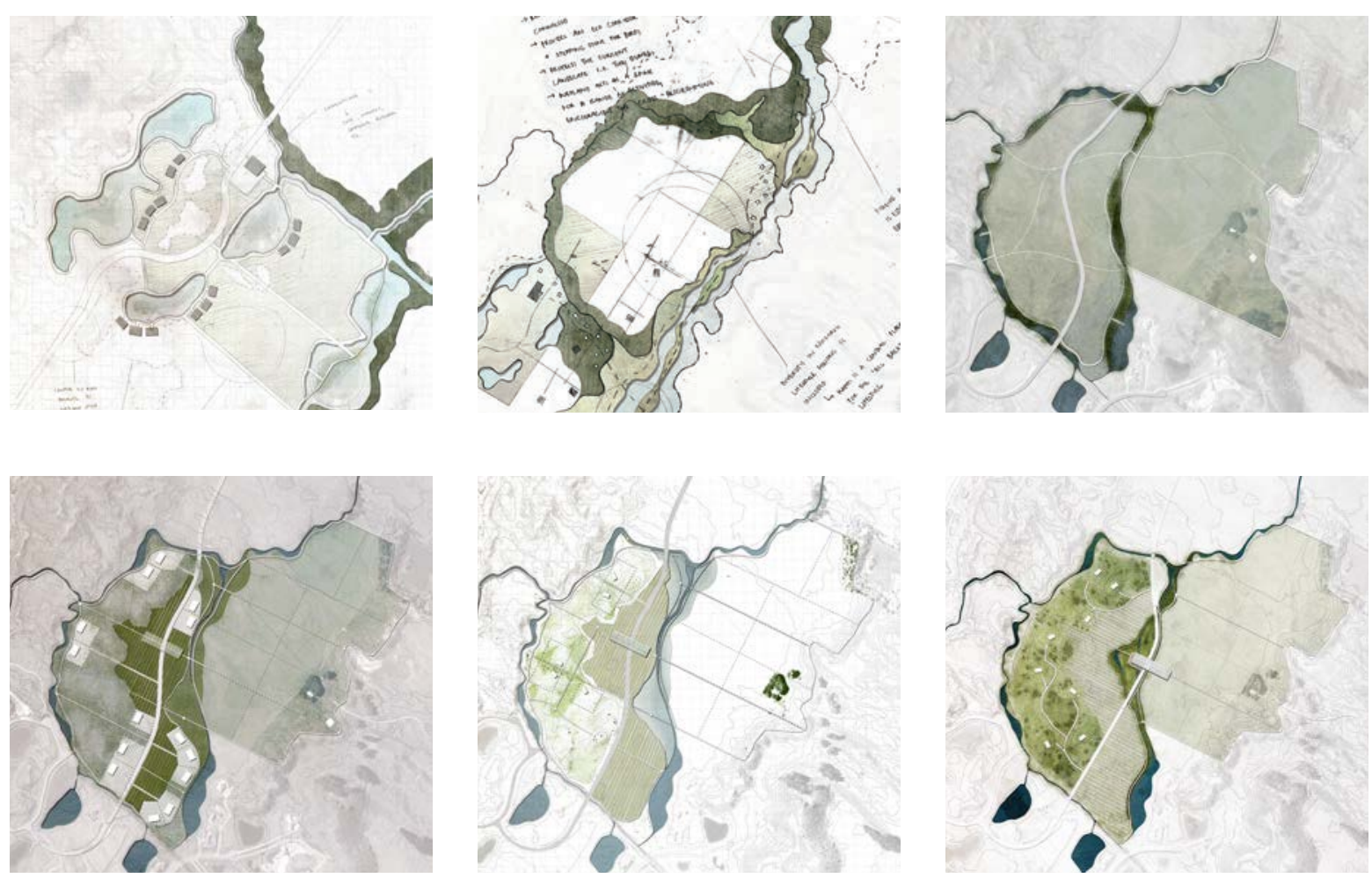

Fig. 119 Design chronology. 


\title{
CONCLUSION
}

\author{
Chapter Five
}

"The loss of biodiversity has progressed to the point that protection of natural areas is no longer an adequate response to protecting the sustainable long-term future of indigenous biodiversity and ecological resilience."

Kapiti Coast District Council - Proposed Kapiti Coast District Plan [2012] 
Land-use tension is a common problem within New Zealand's rural landscape. With the increasing number of lifestyle landowners, the management and design of lifestyle blocks will have a significant impact on land-use within the rural environment. Traditional methods of landuse planning have too long seen a disconnection between planning documents and their actual outcomes. This thesis aims to confront this disconnection by suggesting a new strategies for designing ruralresidential subdivision. These strategies are centred on the integration of land-use, using mutual benefits to produce a level of synergy within the rural landscape.

The design explores a site-specific strategy in dealing with land-use, using soil and water to determine the potential of landscape before determining its use. This provides a guideline which, in combination with the current needs of the region and its community, can determine an appropriate combination of land-uses. Understanding the site on ground level, therefore, becomes a key design tool in which traditional land-use planning lacks.

This strategy is supported by a new management and ownership system, largely based on two key New Zealand precedents; Parkhill Farm in the Hawkes Bay and Hillend in Wanaka. This system capitalises on the demand for coastal land and the commuter culture of Kapiti to use the majority of the site for ecology and production. It also allows for ecological systems, which have no income or discernible value, to become an integral part of the property. It, therefore, becomes the role of design to create a space that convinces potential buyers that this is a viable investment.

Rural subdivisions tend to focus largely on the design of the masterplan, neglecting the qualities of the space and the landscape that ironically are a key selling point for lifestyle blocks. The design primarily focuses on the communal spaces instead of the private property, considering how both the public and the residents can be encouraged to interact with 
the natural environment. The proposed communal spaces are not heavily designed, with few formal pathways or structures. The design instead works to build an ecological and productive foundation that will ultimately be shaped by the community that resides within it, encouraging a sense of ownership and responsibility over the land.

Fundamentally, the design acts as a model for future rural-residential development within the Kapiti Coast. Although it focuses primarily on the coastal strip between the dunes, the basic design principles can be easily applied to other development projects. It also expresses the importance of the Queen's Chain as a tool to care for our waterways. Furthermore, implementation in the focus area could potentially lead to a partial restoration of the Great Swamp, the initial inspiration for the project, within a modern environment. The swampy wetlands were once an integral part of Kapiti's landscape and could become an important part of it once more.

The district plan is inadequate as a tool for land-use planning, its abstract nature fails to acknowledge ground conditions and results in poor implementation. This, however, can be addressed through the design process. Key design tools include the use of sections to connect with the human scale, the creation of a working landscape and a constant exploration at a variety of scales in order to consider both the community and the wider region.

The demand for lifestyle blocks is not going to cease and design has the potential to turn these investments into something that is much more than fancy houses on rural land. The role of the everyday landscape is too often underestimated in design and a good design has the power to change and shape the way it evolves. This will not only benefit ecology, production and the residents, but ultimately create a resilient landscape. 


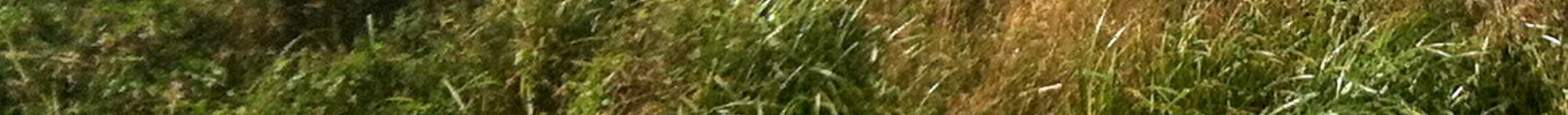

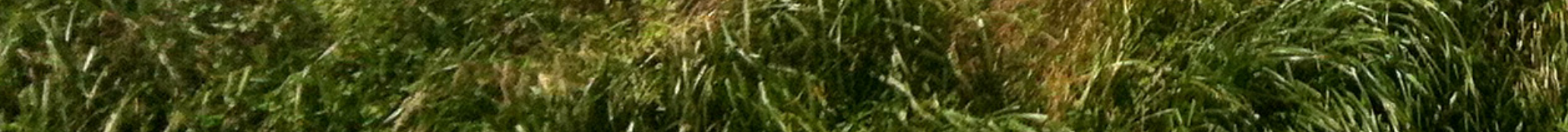

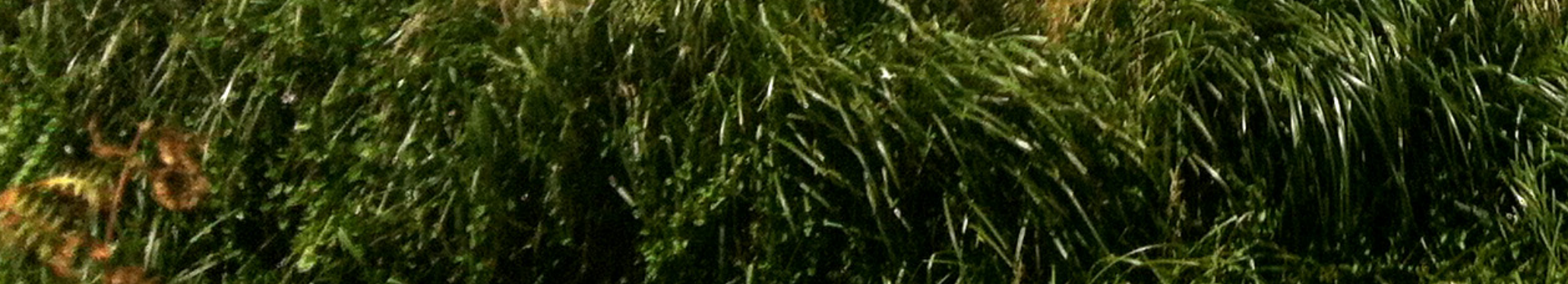

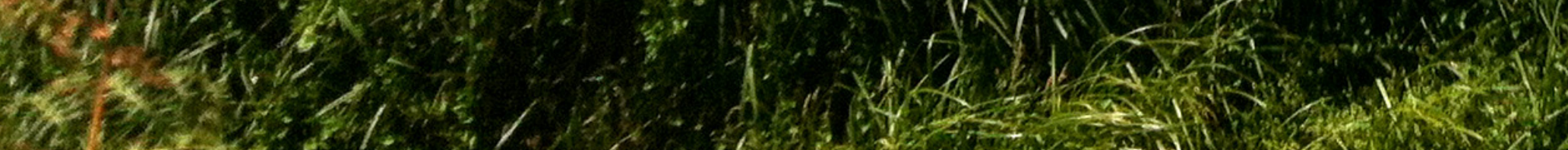

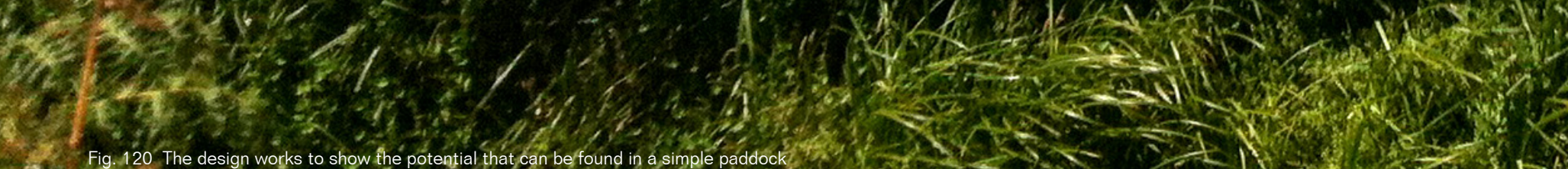
Q7. Fig.120 The design works to show the potential that can befound in a simple paddock 


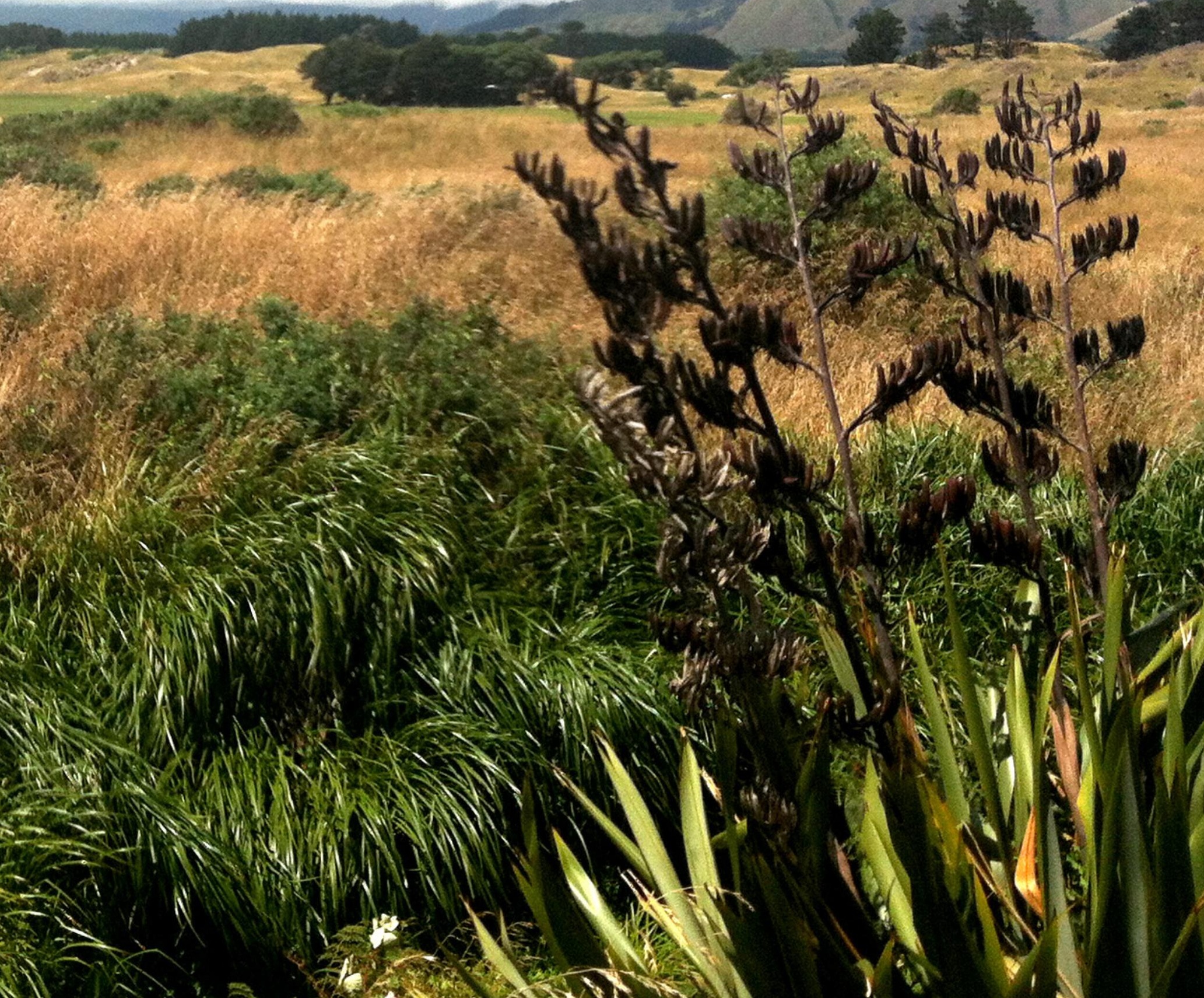




\section{BIBLIOGRAPHY}

Baskaran, Ramesh, Ross Cullen and Sergio Colombo. Estimating Values of

Environmental Impacts of Dairy Farming in New Zealand. 2011. Web. 22. Jan. 2016. <http://nzae.org.nz/wp-content/uploads/2011/08/Estimating_Values_ of_Environmental_Impacts_of_Dairy_Farming_in_New_Zealand.pdf $>$

Beattie, Lee. Plan Implementation: The Reality of Land Use Planning in Auckland, New Zealand. Web. 22 Jan. 2016. <http://www.planning.org.nz/ Folder?Action $=$ View\%20File\&Folder_id $=185 \&$ File $=$ Beattie.pdf $>$

Bentem, Roelof Jan. "Reconstuction and Treatment of Rural Landscape". Shaping Tomorrow's Landscape. Ed. Sylvia Crowe and Zvi Miller. Amsterdam: Djambatan, 1964. Print.

Block, Peter. Community: The Structure of Belonging. San Francisco: Berrett-Koehler Publishers, 2008. Print.

Byrd, Warren. Nelson Byrd Woltz: Garden, Park, Community, Farm. Ed. Stephen Orr. New York: Princeton Architectural Press, 2013. Print.

France, Robert. Wetland design: principles and practices for landscape architects and land-use planners. New York: W. W. Norton, 2003. Print.

Fuller, Stephen. Wetlands in the Wellington Region. Wellington: Regional Council, 1993. Print.

Greater Wellington Regional Council. Air, land and water in the Wellington Region: Kapiti Coast Sub-region. June 2012. Web. 22 Jan. 2016. <http://www. gw.govt.nz/assets/Our-Environment/Environmental-monitoring/EnvironmentalReporting/Kapiti-low-res.pdf>

Hart, Georgina, Daniel Rutledge, Robbie Price, Fiona Curran-Cournane, Haydon James, Andrew Burton and Reece Hill. "A Nationally Consistent Approach for Monitoring Land Fragmentation in New Zealand." Mountains to Sea: NZPI Conference. 5 April 2014. Web. 19 Jan. 2016. <http://www.planning.org.nz/At tachment?Action $=$ Download\&Attachment id $=3116>$ 
Huntsinger, Lynn. What makes a landscape work. Web. 22 Jan. 2016. <http://ucanr. edu/sites/PSU/files/173262.pdf>

Infometrics. Kapiti Coast Annual Economic Profile 2013. Web. 22 Jan. 2016. <http:// www.kapiticoast.govt.nz/contentassets/ d977374c3ae848759d3f30f0b02d291c/annual-economic-profile-2013.pdf>

Kapiti Coast District Council. "Rural Environment". Proposed Kapiti Coast District Plan. Nov. 2012. Web. 22 Jan. 2016. <http://www.kapiticoast.govt.nz/YourCouncil/Planning/District-Plan1/>

Koolhas, Rem. "Koolhas in the country." Icon. Web. 21 Jan. 2016. <http://www. iconeye.com/architecture/features/item/11031-rem-koolhaas-in-the-country>

Landcare Research. "NZ Soil Classification Soil Order." Landcare Research, Web. 22 Jan. 2016. <http://soils.landcareresearch.co.nz/contents/SoilNames_ NZSoilClassification_SoilOrders.aspx?currentPage=SoilNames_ NZSoilClassification_SoilOrders\%26\#B>

Lau, Stephen and Feng Yang. "Introducing Healing Gardens into a Compact University Campus: Design Natural Space to Create Healthy and Sustainable Campuses". Landscape Research: Journal of the Landscape Research Group. Ed. Maggie Roe. Oxfordshire: Routledge Journals, Taylor \& Francis, 2009. 55 - 81. Print.

Lincoln College. Problems of the New Zealand agricultural landscape : a report of the Agricultural Landscape Research Project, Lincoln College, New Zealand. Wellington: Queen Elizabeth the Second National Trust, 1984. Print.

Local Government and Environment Select Committee. Submission of Resource Management Amendment Bill. April 2009. Web. 21 Jan. 2016. <http://www. parliament.nz/resource/0000106449>

McGruddy, Elizabeth. Integrating New Zealand Flax into Land Management Systems. July 2006. Web. 22 Jan. 2016. <http://www.nzpcn.org.nz/publications/ Harakeke-Report06.pdf> 
McHarg, lan. The essential lan McHarg: writings on design and nature. Washington: Island Press, 2006. Print.

Ministry for the Primary Industries. Pastoral Input Trends in New Zealand: A Snapshot. June 2012. Web. 22 Jan. 2016. <https://www.mpi.govt.nz/documentvault/4168>

New Zealand Parliamentary Counsel Office. "Resource Management Act". 1991. New Zealand Legislation. Web. 22 Jan. 2016. <http://www.legislation.govt. nz/act/public/1991/0069/latest/DLM230265.html>

NZTA. "Assessment of Environmental Effects Report". Mackays to Peka Peka Project. 2010. Web. 19 Jan. 2016. <http://www.nzta.govt.nz/assets/projects/ mackays-to-peka-peka-application/docs/aee-section-28.pdf>

Parkhill Farm. Parkhill Farm. 2013. Web. 22 Jan. 2016. <http://www.parkhillfarm. co.nz/>

Pollak, Linda. "Constructed Ground: Questions of Scale." The Landscape Urbanism Reader. Ed. Charles Waldheim. New York: Princeton Architectural Press, 2006. 126 -139. Print.

Polyakov, Maksym, David J. Pannell, Ram Pandit, Sorada Tapsuwan and Geoff Park. "Valuing Environmental Assets on Rural Lifestyle Properties". Agricultural and Resource Econmics Review. April 2013. Web. 22 Jan. 2016. <http:// ageconsearch.umn.edu/bitstream/126941/2/WP120010.pdf>

Sassen, Saskia. "The Global City: Introducing a Concept". The Brown Journal of World Affairs. Brown University, 2005. Web. 22 Jan. 2016. <http://www. saskiasassen.com/pdfs/publications/the-global-city-brown.pdf>

Statistics New Zealand. Statistics New Zealand. Web. 21 Jan. $2016<$ http://www. stats.govt.nz> 
Stuff. "Sales of New Zealand lifestyle blocks tops \$6 billion". Stuff. 24 Jan. 2016.

Web. 28 Jan. 2016. <http://www.stuff.co.nz/business/farming/nz-lifestyleblock/76195215/sales-of-new-zealand-lifestyle-blocks-tops-6-billion>

Walker, Brian and David Salt. Resilience thinking: sustaining ecosystems and people in a changing world. Washington: Island Press, 2006. Print. 


\section{LIST OF ILLUSTRATIONS}

All images not attributed are author's own.

Fig. 11: Flooding in Coastlands, 2015. Source: http:/www.radionz.co.nz/ news/regional/273636/kapiti-coast-wakes-up-to-a-deluge

Fig. 12: Residents kayaking, 2015. Source: https:/twitter.com/onenewsnz/ status/598630415671300096

Fig. 13: Flooded paddocks, 2015. Source: http:/www.thehits.co.nz/breaking-news/ kapiti-coast-hit-by-flooding-what-you-need-to-know

Fig. 15: Soil conditions map. Data Source: https://data.linz.govt.nz/

Fig. 16: Contribution to GDP. Data Source: http://www.kapiticoast.govt.nz/ contentassets/d977374c3ae848759d3f30f0b02d291c/annual-economicprofile-2013.pdf

Fig. 17: Economic growth. Data Source: http://www.kapiticoast.govt.nz/contentassets/ d977374c3ae848759d3f30f0b02d291c/annual-economic-profile-2013.pdf

Fig. 18: Pastoral trends. Data Source: https://www.mpi.govt.nz/document-vault/4168

Fig. 21: Current land-use map. Data Source: https://data.linz.govt.nz/

Fig. 22: Land-use map of most intensive, but sustainable use. Data Source: http:// ourenvironment.scinfo.org.nz/ourenvironment

Fig. 23: Map of the Kapiti Coast. Aerial imagery supplied by LINZ. Source: https:// data.linz.govt.nz/

Fig. 24: Population in Peka Peka. Data Source: http://www.stats.govt.nz

Fig. 25: Population growth. Data Source: http://www.stats.govt.nz

Fig. 26: Dwelling types. Data Source: http://www.stats.govt.nz 
Fig. 27: Broad age groups. Data Source: http://www.stats.govt.nz

Fig. 28: Site Aerial. Source: https://data.linz.govt.nz/

Fig. 29. Te Kowhai Stream. Aerial Imagery supplied by LINZ. Source: https://data.linz. govt.nz/

Fig. 40: Promotional image of Parkhill Farm. Source: http:/www.parkhillfarm.co.nz

Fig. 41: Promotional image of Parkhill Farm. Source: http:/www.parkhillfarm.co.nz

Fig. 42: Promotional image of Parkhill Farm. Source: http:/www.parkhillfarm.co.nz

Fig. 76: Woven harakeke baskets. Source: https:/weavingpapaka.files.wordpress. com/2010/02/kono-1.jpg

Fig. 77: Harakeke fibre. Source: https:/weavingpapaka.files.wordpress.com/2010/02/ kono-1.jpg

Fig. 95: Lakeway Redevelopment. Source: http://www.landezine.com/index. php/2013/12/lakeway-redevelopment-by-hassell/

Fig. 96: Lakeway Redevelopment. Source: http://www.landezine.com/index. php/2013/12/lakeway-redevelopment-by-hassell/

Fig. 97: Lakeway Redevelopment. Source: http://www.landezine.com/index. php/2013/12/lakeway-redevelopment-by-hassell/

Fig. 98: Lakeway Redevelopment. Source: http://www.landezine.com/index. php/2013/12/lakeway-redevelopment-by-hassell/

Fig. 99: Lakeway Redevelopment. Source: http://www.landezine.com/index. php/2013/12/lakeway-redevelopment-by-hassell/

Fig. 103: Hillend Station. Source: http://www.hillendstation.com/ 
Fig. 104: Hillend Station. Source: http://www.hillendstation.com/

Fig. 105: Hillend Station. Source: http://www.hillendstation.com/

Fig. 113: Orongo Station. Source: http://www.nbwla.com/projects/farm/orongostation-conservation-masterplan

Fig. 114: Gardens of Orongo Station. Source: http://www.nbwla.com/projects/farm/ orongo-station-conservation-masterplan

Fig. 115: Orongo Station. Source: http://www.nbwla.com/projects/farm/orongostation-conservation-masterplan

Fig. 116: Diagram of Orongo project. Source: https:/www.asla.org/2010awards/205. html

Fig. 117: Termain, Garrick. The Queen's Chain. Source: http:/www.teara.govt.nz/files/c8535-enz.gif 
